$10-2006$

\title{
Archeological Impact Evaluations and Surveys in the Texas Department of Transportation's Abilene, Brownwood, Fort Worth, and Waco Districts, 2003-2006
}

Jennifer K. McWilliams

Texas Historical Commission

Ross C. Fields

Prewitt and Associates, Inc.

Karl W. Kibler

Cross Timbers Geoarcheological Services

E. Frances Gadus

Prewitt and Associates, Inc.

Douglas K. Boyd

Prewitt and Associates, Inc.

See next page for additional authors

Follow this and additional works at: https://scholarworks.sfasu.edu/ita

Part of the American Material Culture Commons, Archaeological Anthropology Commons, Environmental Studies Commons, Other American Studies Commons, Other Arts and Humanities Commons, Other History of Art, Architecture, and Archaeology Commons, and the United States History Commons

Tell us how this article helped you.

This Article is brought to you for free and open access by the Center for Regional Heritage Research at SFA ScholarWorks. It has been accepted for inclusion in Index of Texas Archaeology: Open Access Gray Literature from the Lone Star State by an authorized editor of SFA ScholarWorks. For more information, please contact cdsscholarworks@sfasu.edu. 


\section{Archeological Impact Evaluations and Surveys in the Texas Department of Transportation's Abilene, Brownwood, Fort Worth, and Waco Districts, 2003-2006}

Authors

Jennifer K. McWilliams, Ross C. Fields, Karl W. Kibler, E. Frances Gadus, Douglas K. Boyd, and Timothy B. Griffith

Creative Commons License

(c) (i) $(\Theta)$

This work is licensed under a Creative Commons Attribution-NonCommercial-No Derivative Works 4.0 International License. 


\title{
ARCHEOLOGICAL IMPACT EVALUATIONS AND SURVEYS IN THE TEXAS DEPARTMENT OF TRANSPORTATION'S ABILENE, BROWNWOOD, FORT WORTH, AND WACO DISTRICTS, 2003-2006
}

\author{
by \\ Jennifer K. McWilliams \\ Ross C. Fields \\ Karl W. Kibler \\ E. Frances Gadus \\ Douglas K. Boyd \\ and \\ Timothy B. Griffith
}

with contributions by
Cory J. Broehm and
Tim Gibbs

Principal Investigator: Ross C. Fields

REPORTS OF INVESTIGATIONS, NUMBER 148

Prewitt and Associates, Inc.

Cultural Resources Services

Austin, Texas

ARCHEOLOGICAL STUDIES PROGRAM, REPORT NO. 93

Texas Department of Transportation

Environmental Affairs Division

October 2006

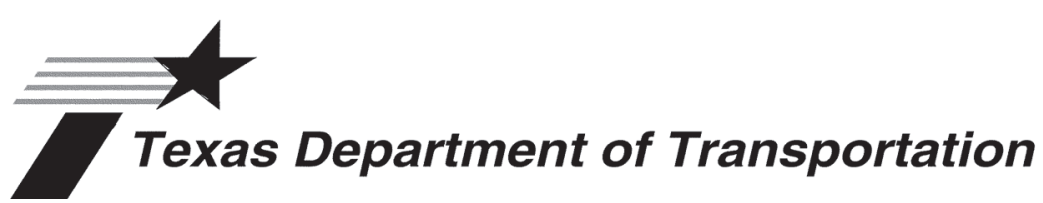




\section{ARCHEOLOGICAL IMPACT EVALUATIONS AND SURVEYS \\ IN THE TEXAS DEPARTMENT OF TRANSPORTATION'S \\ ABILENE, BROWNWOOD, FORT WORTH, AND \\ WACO DISTRICTS, 2003-2006}

\section{COPYRIGHT @ 2006}

Texas Department of Transportation (TxDOT) and Prewitt and Associates, Inc. (PAI)

TxDOT and PAI jointly own all rights, title, and interest in and to all data and other information developed for this project under Contract 574XXSA002. Brief passages from this publication may be reproduced without permission provided that credit is given to TxDOT and PAI. Permission to reprint an entire chapter, section, figures or tables must be obtained in advance from the Supervisor of the Archeological Studies

Program, Environmental Affairs Division, Texas Department of Transportation, 125 East 11th Street, Austin, Texas, 78701.

jointly published by the

Texas Department of Transportation

Environmental Affairs Division

Archeological Studies Program

Lisa Hart, Director, Cultural Resources Management Section

Archeological Studies Program, Report No. 93

Al McGraw, Series Editor

and

Prewitt and Associates, Inc.

Cultural Resources Services

Austin, Texas

PAI Project Nos. 203042 and 206023

Reports of Investigations, Number 148

Printed by Morgan Printing in Austin, Texas

ISBN 1-930788-10-X 


\section{TABLE OF CONTENTS}

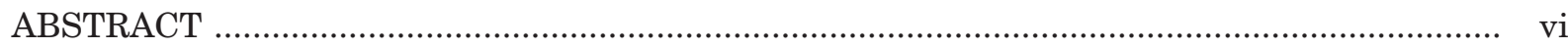

ACKNOWLEDGEMENTS ................................................................................................ vii

CHAPTER 1: INTRODUCTION AND ENVIRONMENTAL BACKGROUND ............................ 1

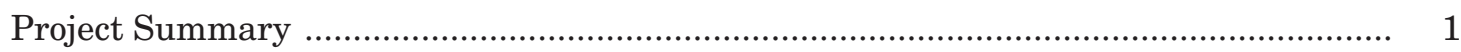

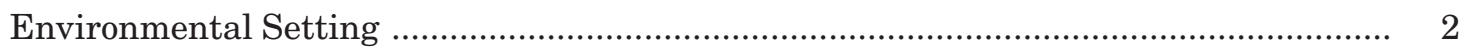

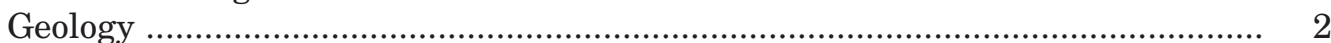

Natural Regions and Vegetation ................................................................... 3

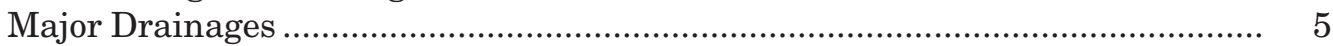

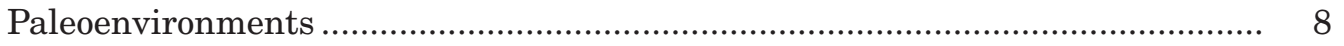

CHAPTER 2: SYNOPSIS OF NATIVE AMERICAN CULTURE HISTORY .............................. 11

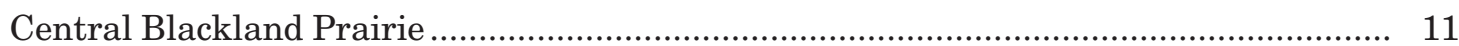

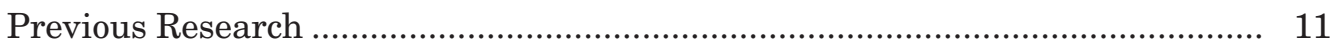

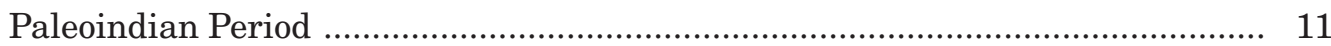

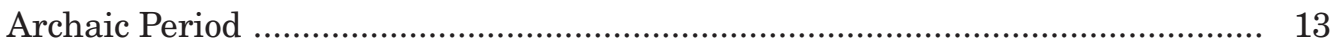

Late Prehistoric Period ................................................................................ 14

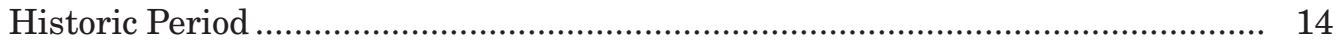

Northern and Northeastern Central Texas ............................................................... 15

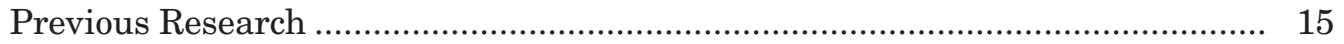

Paleoindian Period ….................................................................................... 15

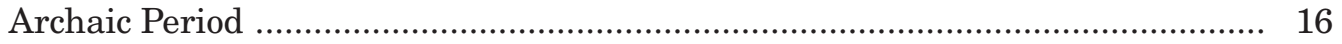

Late Prehistoric Period …............................................................................ 18

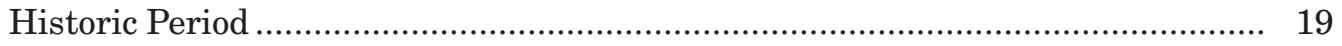

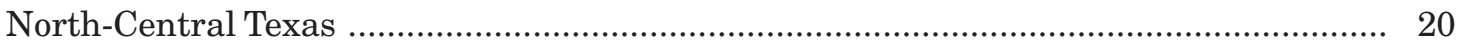

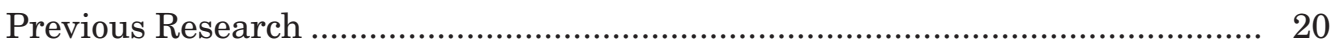

Paleoindian Period ...................................................................................... 20

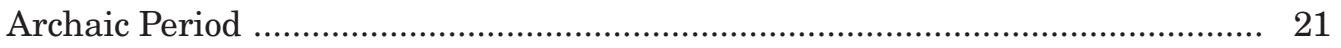

Late Prehistoric Period ............................................................................. 22

Historic Period ............................................................................................ 23

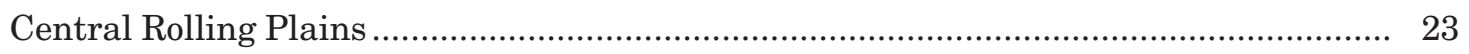

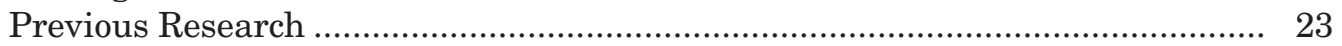

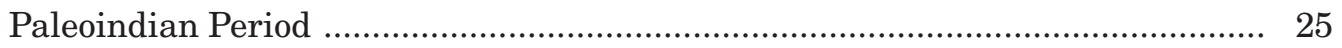

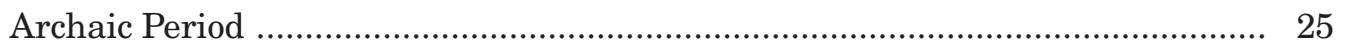

Late Prehistoric Period …......................................................................... 27

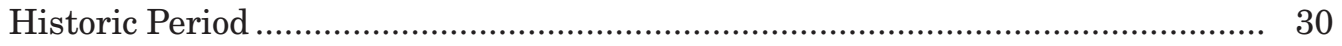

CHAPTER 3: SUMMARY OF IMPACT EVALUATIONS AND SURVEYS ............................... 31

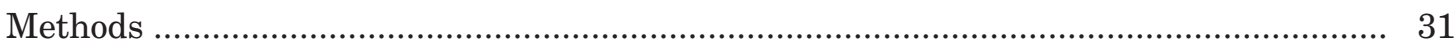

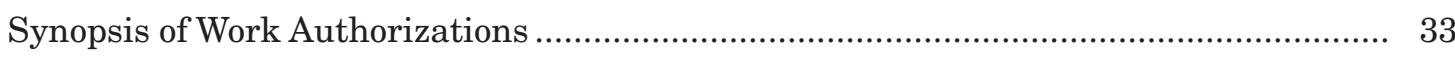




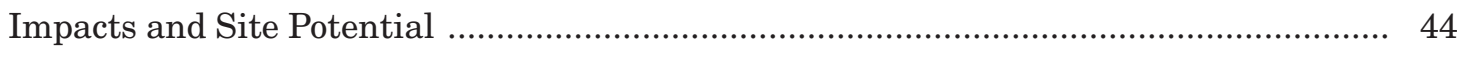

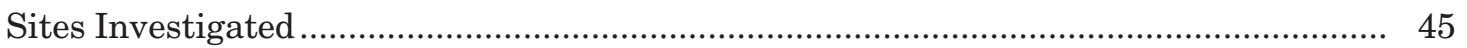

41BQ285, Work Authorization 28 ........................................................... 55

41CV1636, Work Authorization 27 ...................................................... 56

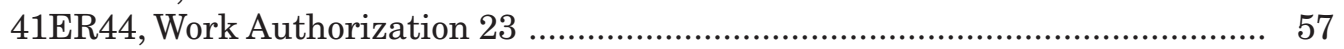

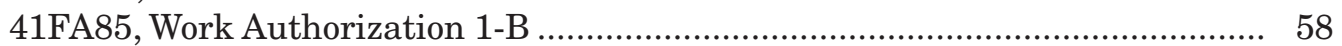

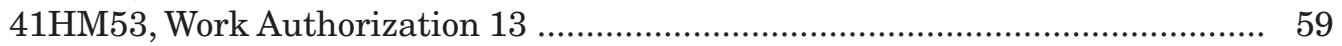

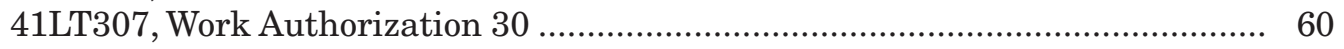

41SV4 and 41SV51, Work Authorization 8 …................................................... 61

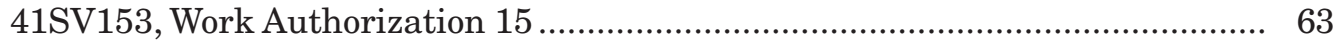

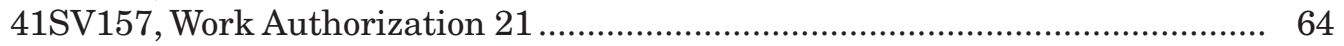

Patterns in Site Distributions ...................................................................... 65

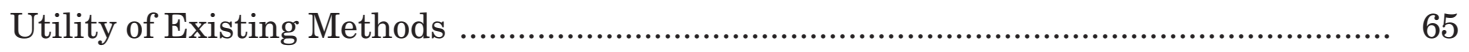

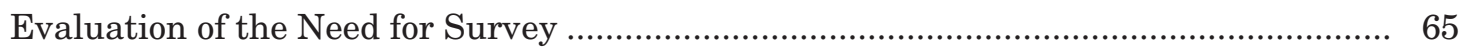

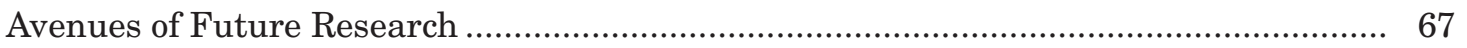

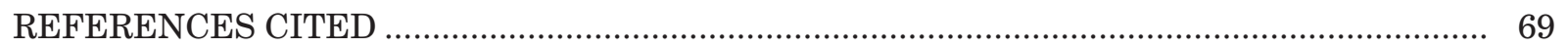

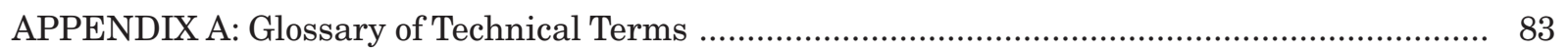

APPENDIX B: Letters and Letter Reports for Impact Evaluations and Surveys ...................... 87 


\section{LIST OF FIGURES}

1. Locations of the Abilene, Brownwood, Fort Worth, and Waco Districts

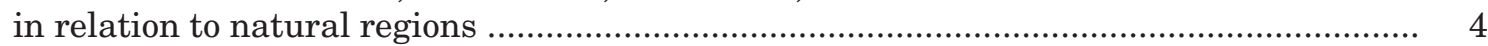

2. Major drainages in the Abilene, Brownwood, Fort Worth, and Waco Districts ................. 6

3. Map showing the four culture history summary areas .................................................. 12

4. Map of the study area showing the locations of all Impact Evaluations and Surveys ....... 32

5. Schematic cross section of a bridge approach showing common disturbance factors ......... 45

\section{LIST OF TABLES}

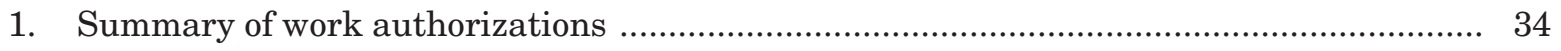

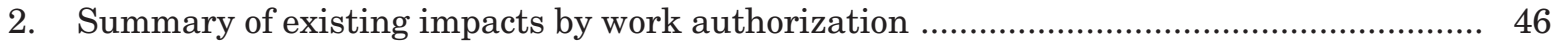

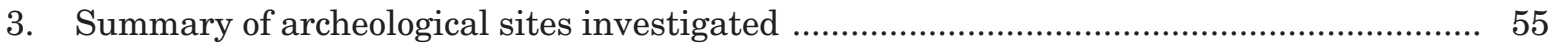




\begin{abstract}
This document constitutes the final report of work done by Prewitt and Associates, Inc. (PAI), under a contract from the Texas Department of Transportation (TxDOT) to provide archeological services in four TxDOT districts-Abilene, Brownwood, Fort Worth, and Waco. Under this contract, PAI completed Impact Evaluations and Surveys to assist TxDOT in meeting the requirements of their Memorandum of Understanding with the Texas Historical Commission and a Programmatic Agreement between the Advisory Council on Historic Preservation, the Federal Highway Administration, the Texas Historical Commission, and TxDOT. The contract began on 26 September 2003. A total of 77 projects were conducted.
\end{abstract}

The 77 projects consisted of 25 Impact Evaluations and 52 Surveys. Combined, these entailed efforts at 52 bridge replacements, 14 road realignment or widening projects (many also involving bridge replacements), 1 new road construction project, 1 hike-and-bike trail construction project, 5 projects involving upgrading or replacing existing culverts, 1 project involving construction of drainage improvements, 2 unspecified road maintenance or improvement projects, and 1 project involving replacement of an interstate highway interchange.

Of the 25 Impact Evaluations done, 8 led to recommendations that survey could be needed before construction. In 4 cases, the need for survey depended on whether new right of way would be acquired, which was unknown when the Impact Evaluations were done. The other 17 Impact Evaluations resulted in recommendations that no survey be required before construction based on the limited potential for sites with good integrity. Of the 52 Surveys done under this contract, 9 investigated six newly recorded and four previously recorded sites; eight of the sites are prehistoric, and two are of historic age. Four prehistoric sites were recommended for testing to assess eligibility for listing in the National Register of Historic Places and designation as State Archeological Landmarks, and one historic site was recommended for archival and oral history research. The other 43 Surveys did not find any archeological sites.

All artifacts collected and records generated by projects done under this contract are curated at the Texas Archeological Research Laboratory (TARL), The University of Texas at Austin. Artifacts were collected from five sites (41BQ285, 41CV1636, 41HM53, 41LT307, amd 41SV4). Those from 41HM53 and 41SV4 are from State-owned lands and thus are curated in a held-in-trust status at TARL. The artifacts from 41BQ285, 41CV1636, and 41LT307 are from private lands and are curated in a non-held-in-trust status. 


\section{ACKNOWLEDGMENTS}

A number of people contributed to the successful completion of this project. G. Lain Ellis managed the contract for the Archeological Studies Program, Environmental Affairs Division, Texas Department of Transportation, with the oversight of Owen Lindauer and Nancy Kenmotsu and the assistance of Jon Budd and G. R. Dennis Price. At Prewitt and Associates, Ross C. Fields served as principal investigator, and Douglas K. Boyd was the quality control officer. Cory J. Broehm, Ross Fields, Tim Gibbs, Timothy B. Griffith, Jennifer K. McWilliams, and Karl W. Kibler served as project archeologists. These people performed most of the fieldwork and were responsible for writing most of the reports on individual work authorizations included as Appendix B; the site descriptions included in the body of the report are extracted from the work authorization reports. Mr. Kibler prepared the Environmental Setting section of the report and one of the culture history summaries (Northern and Northeastern Central Texas). E. Frances Gadus wrote the culture history summary for NorthCentral Texas. Douglas K. Boyd and Mr. Griffith co-authored the culture history summary for the Central Rolling Plains. Ms. McWilliams and Mr. Fields wrote the remainder of the report. Support at Prewitt and Associates was provided by Karen M. Gardner (laboratory supervision, photograph cataloging, and curation); Brian J. Wootan (production of graphics); and Sandra L. Hannum (production of graphics and this report). 



\section{INTRODUCTION AND ENVIRONMENTAL BACKGROUND}

\section{PROJECT SUMMARY}

This document constitutes the final report of work done by Prewitt and Associates, Inc. (PAI), under a contract (\#574XXSA002) with the Texas Department of Transportation (TxDOT) to provide archeological services in four TxDOT Districts-Abilene, Brownwood, Fort Worth, and Waco-in the central, north-central, and northwestern parts of the state. The contract began on 26 September 2003, and the last work authorization, for preparing this report, was issued on 26 April 2006. During those two-and-a-half years, fieldwork was done under 32 work authorizations (30 under Contract \#574XXSA002 and 2 additional work authorizations under Contract \#575XXSA006 to finish up work started under the other contract). Texas Antiquities Permit No. 3243 was issued by the Texas Historical Commission to cover the work done under these work authorizations.

Under this contract, PAI completed Impact Evaluations and Surveys to assist TxDOT in meeting the requirements of their Memorandum of Understanding with the Texas Historical Commission and a Programmatic Agreement among the Advisory Council on Historic Preservation, the Federal Highway Administration, the Texas Historical Commission, and TxDOT. TxDOT defines Impact Evaluations as "on-site inspection ... documenting existing impacts or other conditions which may preclude the presence of intact archeological deposits within the project area for a proposed Transportation Activity." Impact Evaluations are thus an initial step to determine whether survey of a particular area is warranted, given the anticipated effects of the project, the existing level of disturbance, and the likelihood of archeological deposits in good context.

TxDOT defines Surveys as "archeological field work ... of a proposed Transportation Activity to locate archeological remains, if any, including on-foot examination of the surface, shovel testing, and subsurface trenching by mechanical means where appropriate." As described below, PAI completed 77 projects involving 25 Impact Evaluations and 52 Surveys. No surveys included formal geoarcheological evaluations. Most of these projects focused on locations where bridges will be replaced. Other kinds of Transportation Activities included roadwidening projects, upgrading or replacing existing culverts, drainage improvements, construction of a new relief route, construction of a hike-and-bike trail, unspecified road maintenance, and reconstruction of a highway interchange.

During completion of these work authorizations, 10 newly discovered or previously recorded archeological sites were investigated. All artifacts collected and records generated are curated at the Texas Archeological Research Laboratory (TARL), The University of Texas at Austin. Artifacts were collected from five sites: 41BQ285, 41CV1636, 41HM53, 41LT307, and 41SV4.

The body of this report consists of three major sections. A brief characterization of the environmental setting of the four TxDOT districts follows this introduction. Four synopses of Native American culture histories are presented next. The first focuses on the central Blackland Prairie in the eastern Waco District. The second deals with the northern and northeastern portions of central Texas- the eastern Edwards Plateau and adjacent Blackland Prairie margin, the Llano Uplift, the southern parts of the Grand Prairie and the Eastern and Western Cross 
Timbers, and the southern edge of the Rolling Plains-and encompasses the central and western parts of the Waco District, the southern part of the Brownwood District, and the southern edge of the Fort Worth District. The third discusses the northern Grand Prairie and Eastern and Western Cross Timbers and adjacent eastern margin of the Rolling Plains of north-central Texas; most of the Fort Worth District is in this region. The final culture history section deals with the central Rolling Plains of northwest Texas, encompassing the Abilene District and the northern part of the Brownwood District.

After the culture history synopses is a section summarizing the work done under this contract that discusses the methods employed in the Impact Evaluations and Surveys and evaluates their effectiveness. It also presents tables listing the Impact Evaluations and Surveys and their topographic and geologic settings, soils, land use, and presence or absence of archeological sites. Existing disturbances that affected the potential of project areas to contain sites with sufficient integrity to be eligible for National Register of Historic Places listing or State Archeological Landmark designation are listed and discussed. The sites investigated are described next. This section also provides an evaluation of the need for survey based on the results of this project. A references cited section and two appendixes follow the body of the report. Appen$\operatorname{dix} \mathrm{A}$ is a glossary of technical terms, and Appendix B (on CD-ROM) contains the letters and reports submitted to TxDOT for all Impact Evaluations and Surveys done under the contract.

\section{ENVIRONMENTAL SETTING}

\section{Geology}

The Abilene, Brownwood, Fort Worth, and Waco Districts cover a 39-county area in central, north-central, and northwestern Texas. The southeastern portion of this four-district area lies within the Western Gulf Coastal Plain physiographic province, the western and northwestern portions lie within the Great Plains province, and a small part of the northern portion lies in the Osage section of the Central Lowlands province (Fenneman 1931, 1938). The intersection of these three physiographic provinces has had an interesting and dynamic geologic history (see Spearing 1991).

Geologically, the four-district area straddles a deep-seated fracture zone and site of past orogenic events that separates the stable continental interior to the west from the subsiding Gulf basin to the east and southeast (Hayward 1988a, 1988b). The early geologic history of the area is evidenced in the rocks in the southern part of the Brownwood District. Tectonic events during the Precambrian metamorphosed sediments deposited along the margin of the continent into gneiss and schists, which later were penetrated by intrusive granitic rocks. Marine transgression during the early Paleozoic followed, and sandy sediments were deposited along the edge of the sea. Farther to the east and southeast, limestones and dolomites were deposited in the deeper open waters. Continued transgression covered the earlier rock units with extensive dolomites, limestones, sandstones, and shales, which now form the tilted flanks of the Llano Uplift. Toward the end of the Paleozoic (Pennsylvanian), the Ouachita Mountains rose along the margin of the continent due to tectonic events related to formation of the supercontinent Pangaea. The rise of the Ouachita Mountains along this zone in the Paleozoic resulted in the deposition of clastic sediments and carbonates on a broad shelf along the margin of the Permian Basin southwest of the four-district area. These sediments formed the Pennsylvanian and Permian rock units of the western and northwestern parts of the project area. These sandstone, mudstone, and limestone units dip and become progressively younger toward the basin.

Later during the Cretaceous period as the Gulf of Mexico formed, clastic sediments and carbonates were deposited over the worn-down Ouachita Mountains and late Paleozoic rocks, and along the broad marginal shelf of the Gulf basin. The Lower Cretaceous sandstones, mudstones, limestones, and marls found throughout parts of the Abilene, Brownwood, Fort Worth, and Waco Districts represent cycles of marine transgression and regression throughout the period. By Upper Cretaceous times, infilling of the Gulf basin and shoreline progradation predominated, as evidenced by Upper Cretaceous sandstones and mudstones throughout the eastern parts of the Fort Worth and Waco districts. Marine regression and shoreline progradation 
continued during the Tertiary and Quaternary and are represented by various sandstone and mudstone units present in the eastern parts of the Waco District.

\section{Natural Regions and Vegetation}

The different rock units have a major influence on the topography, flora, and hydrology across the four-district area. Eleven different natural subregions lie within the area due in part to these lithological variations (Figure 1). These 11 subregions are the the Oak Woodlands, Eastern Cross Timbers, and Western Cross Timbers of the Oak Woods and Prairies region; the Blackland Prairie and Grand Prairie of the Blackland Prairies region; the Live Oak-Mesquite Savanna and Lampasas Cut Plain of the Edwards Plateau region; the Llano Uplift region; the Escarpment Breaks and Mesquite Plains of the Rolling Plains region; and the High Plains region (LBJ School of Public Affairs 1978).

The Oak Woodlands subregion encompasses the far eastern margin of the Waco District. The Eastern and Western Cross Timbers cover the eastern and central parts of the Fort Worth District, small parts of the northern Waco District, and the east-central part of the Brownwood District. The Blackland Prairie subregion covers the eastern parts of the Fort Worth and Waco Districts, while the Grand Prairie subregion extends through the central and eastern portions of the Waco and Fort Worth Districts, respectively. The Lampasas Cut Plain subregion is limited to the southwestern portion of the Waco District, the southeastern and central portions of the Brownwood District, and the extreme southeastern corner of the Abilene District. The Llano Uplift is limited to the southern part of the Brownwood District. The Mesquite Plains subregion covers most of the Abilene District, the northern and western portions of the Brownwood District, and the northwestern corner of the Fort Worth District. The Escarpment Breaks subregion and the High Plains region are limited to the extreme western portion of the Abilene District.

The modern plant communities vary from subregion to subregion. The Oak Woodlands subregion consists of overcup oak, post oak, and black hickory deciduous forests, and bluejack oak, pine, post oak, and blackjack oak deciduous woodlands (Diamond et al. 1987). The flora of the Eastern Cross Timbers consists of deciduous forests of post oak and black hickory, and post oak and blackjack oak woodlands, while the Western Cross Timbers are primarily post oak and blackjack oak deciduous woodlands (Diamond et al. 1987).

The Blackland Prairie subregion consists of tall grasslands (dominants greater than $1 \mathrm{~m}$ tall), primarily little bluestem and Indiangrass, with riparian deciduous forests of sugarberry and elm (Diamond et al. 1987). The Grand Prairie subregion is a mixed grass prairie dominated by little bluestem and containing isolated live oak mottes, junipers, and mesquite savannas (Hayward et al. 1996).

Plant communities of the Lampasas Cut Plain include deciduous woodlands of Texas oak and riparian deciduous forests of sugarberry and elm (Diamond et al. 1987). The flora of the Balcones Escarpment is a complex mosaic of bald cypress, sycamore, sugarberry, and elm deciduous forests; juniper and live oak evergreen woodlands; and lacey and Texas oak deciduous woodlands. The Live Oak-Mesquite Savanna of the Edwards Plateau consists of riparian forests of sugarberry and elm, evergreen woodlands of juniper and live oak, deciduous woodlands of lacey and plateau live oak, and deciduous shrublands (greater than 26 percent canopy cover of shrubs less than $0.5 \mathrm{~m}$ tall) of Mohr's shin oak. Short (dominants less than $0.5 \mathrm{~m}$ ) to medium-tall (dominants $0.5-1.0 \mathrm{~m}$ ) grasslands of curlymesquite, sideoats grama, blue grama, and buffalograss also are part of the Live Oak-Mesquite Savanna plant community. Riparian deciduous forests of sugarberry and elm and deciduous woodlands of plateau live oak characterize the Llano Uplift region.

The Mesquite Plains subregion of the Rolling Plains contains riparian deciduous forests of sugarberry and elm and evergreen shrublands of Harvard shin oak, oneseed juniper, redberry juniper, and sandsage (Diamond et al. 1987). Deciduous shrublands of Mohr's shin oak, medium-tall grasslands of little bluestem and sideoats grama, and marshes of saltgrass also are part of the plant community. Floral communities of the Escarpment Breaks subregion include riparian deciduous forests of sugarberry and elm; evergreen woodlands of Rocky Mountain juniper; evergreen shrublands of Harvard shin oak, oneseed juniper, and 


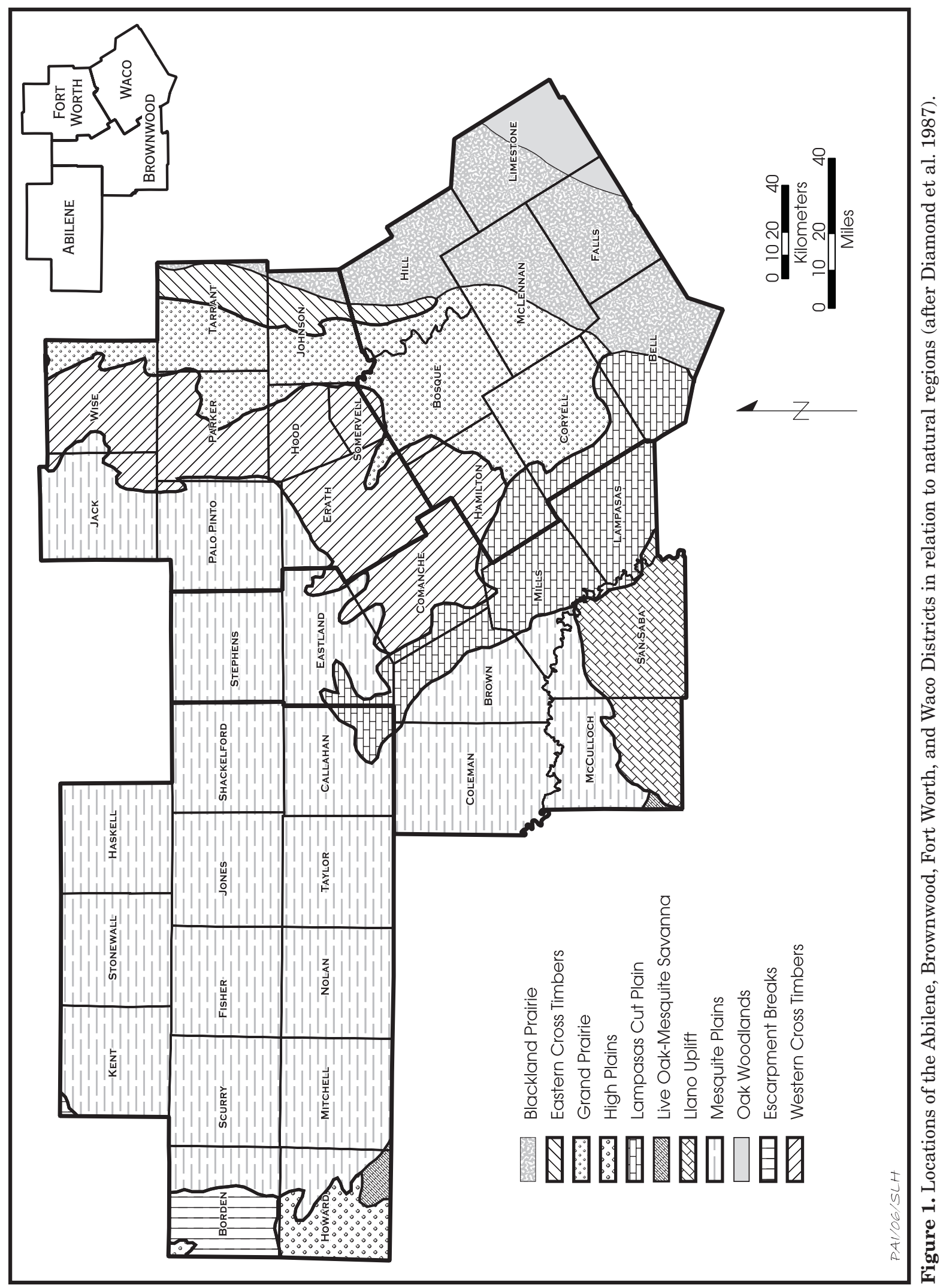


redberry juniper; deciduous shrublands of Mohr's shin oak; and marshes of saltgrass.

The High Plains region consists of Harvard shin oak, oneseed juniper, redberry juniper, and sandsage evergreen shrublands; medium-tall grasslands of sideoats grama; and short grasslands of blue grama, buffalograss, and tobosa (Diamond et al. 1987).

\section{Major Drainages}

The major drainages within the four-district area are the Trinity, Brazos, and Colorado Rivers (Figure 2). Two major branches of the Trinity River, the West Fork and Clear Fork, flow through the Fort Worth District and merge with the Elm Fork to form the Trinity River just east of the Fort Worth District. From here the Trinity River flows southeast outside the four-district area.

Within the Fort Worth District, the branches of the Trinity River all contain Holocene alluvium below floodplains that are up to $1 \mathrm{~km}$ wide. One of the larger branches, the West Fork, has a narrow floodplain (less than $1 \mathrm{~km}$ ), and no Pleistocene terraces are mapped as it flows southeast across Jack and Wise Counties (Hentz and Brown 1987; McGowen et al. 1967). However, as it enters Tarrant County it flows south and then abruptly turns eastward to flow through the City of Fort Worth; it is along this stretch that extensive Holocene and Pleistocene alluvial surfaces are mapped (McGowen et al. 1972). Several tributaries of the West Fork flow southeast across Wise County (Big Sandy Creek and Denton Creek) and northeast across Johnson and Tarrant Counties (Clear Fork and Village Creek). Holocene floodplains averaging $1 \mathrm{~km}$ wide are mapped along these tributaries, as well as remnants of Pleistocene terraces (McGowen et al. 1967, 1972).

Branches of the Brazos River head west and northwest of the study area. Its tributaries, the Double Mountain Fork and Salt Fork, flow across the northern portion of the Abilene District, converging in Stonewall County. From here the Salt Fork flows northeast and exits the Abilene District. Another major branch, the Clear Fork, begins in the central part of the Abilene District and flows east and northeast merging with the Salt Fork just north of the Brownwood District to form the Brazos River. From this point, the Brazos River flows southeast, reentering the study area in Palo Pinto County of the Fort Worth District. It continues to flow southeast across Parker, Hood, and Somervell Counties of the Fort Worth District. It enters the Waco District flowing southeast across Bosque, Hill, McLennan, and Falls Counties.

From the City of Waco upstream to the confluence of the Clear Fork and Salt Fork of the Brazos, the Holocene floodplain of the Brazos River is very narrow (if not absent), and at Lake Whitney and Possum Kingdom Lake it is below the surfaces of the flood pools (Brown et al. 1972; Hentz and Brown 1987; McGowen et al. 1972; Proctor et al. 1970). Pleistocene terraces are extensive along this stretch of the Brazos. Downstream from Waco, the Brazos River enters the Gulf Coastal Plain, and the Holocene floodplain is ca. $6-7 \mathrm{~km}$ wide and bordered by segmented Pleistocene terraces (Proctor et al. 1970). Dissected remnants of higher gravelly Pleistocene terraces are also sporadically located along the upper slopes of the Brazos River valley.

Several large tributaries of the Brazos traverse the four-district area. In the Abilene District, large tributaries with mapped Holocene alluvium are the Clear Fork and Salt Fork. The Clear Fork has a floodplain that is less than 1.0 to $2.5 \mathrm{~km}$ wide and is rarely flanked by Pleistocene terrace segments (Brown et al. 1972; Eifler et al. 1974; Hentz and Brown 1987). Tributaries of the Clear Fork with mapped Holocene alluvium traversing the Abilene and Brownwood Districts include Buffalo Draw and Alkali, Bitter, California, Cedar, Cottonwood, Deadman, Elm, Foyle, Gonzales, Hubbard, Lytle, Mulberry, Noodle, Plum, and Sweetwater Creeks.

The Salt Fork has a floodplain that is less than 1 to $2 \mathrm{~km}$ wide. Segmented Pleistocene terraces are present along the Salt Fork but are not common (Eifler et al. 1967). Tributaries of the Salt Fork with mapped Holocene alluvium traversing the Abilene District include the White River, Duck Creek, Croton Creek, Double Mountain Fork, and North Croton Creek.

From the confluence of the Salt and Clear Forks of the Brazos downstream to the City of Waco, several Brazos River tributaries within the Brownwood, Fort Worth, and Waco Districts display mapped Holocene alluvium. These tributaries include the Nolan and Paluxy Rivers and Aquilla, Big Caddo, Big Cedar, Childress, Dry, Keechi, Kickapoo, and Palo Pinto Creeks (Brown et al. 1972; McGowen et al. 1972; Proctor et al. 


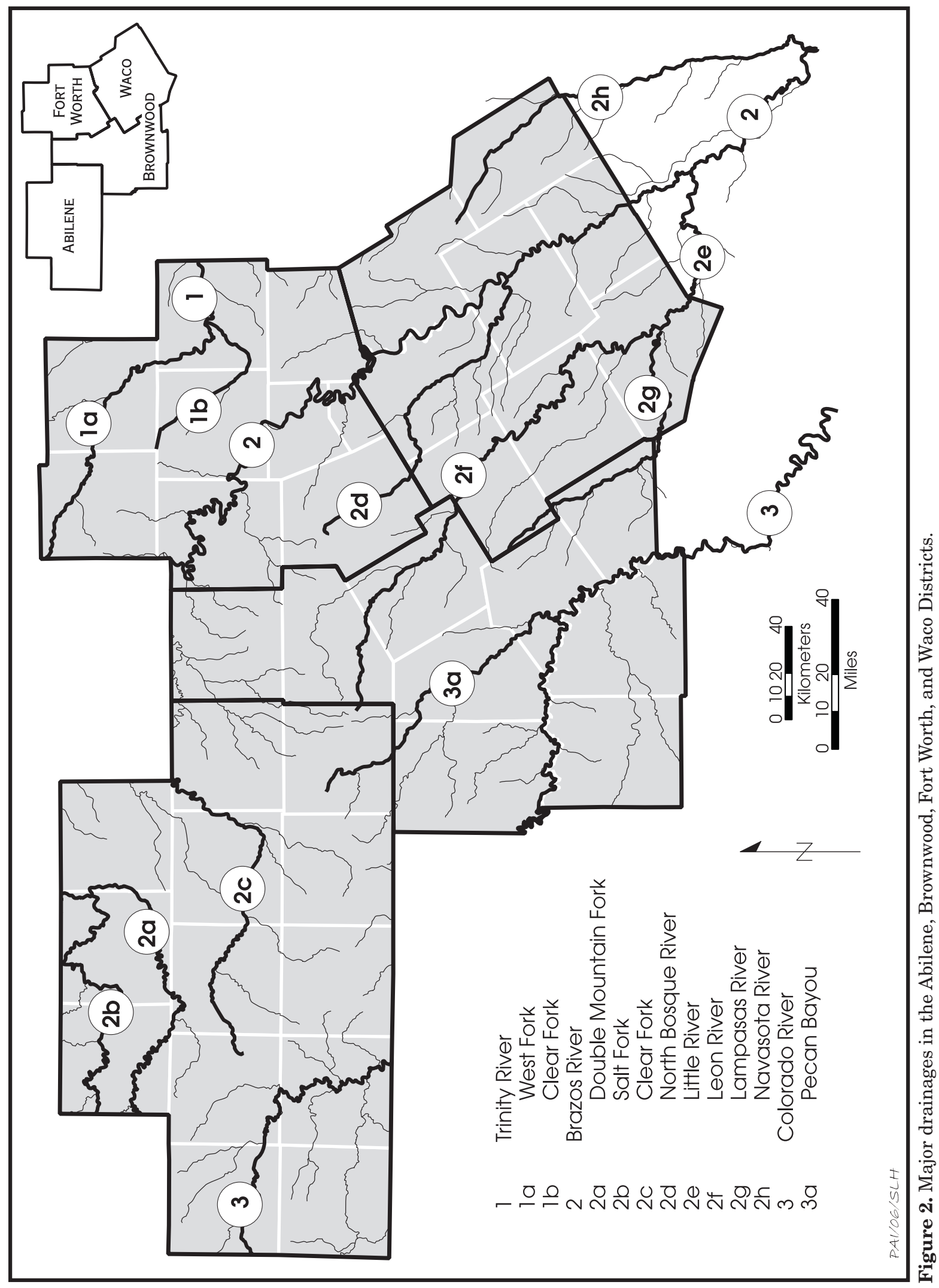


1970). Floodplains of these drainages measure less than $1 \mathrm{~km}$ to just over $1 \mathrm{~km}$ in width. The larger streams such the Nolan and Paluxy Rivers and Palo Pinto, Aquilla, and Childress Creeks display small remnants of Pleistocene terraces.

At Waco and downstream to the southern edge of the study area, the North Bosque and Leon Rivers enter the Brazos River. The North Bosque River heads in Erath County in the Fort Worth District and enters the Waco District in Hamilton County, flowing southeast and east through Hamilton, Bosque, and McLennan Counties before entering the Brazos valley. Its Holocene floodplain is ca. $1 \mathrm{~km}$ wide and bordered by a few small Pleistocene terrace segments or the bedrock valley wall (Brown et al. 1972; Proctor et al. 1970). Tributaries of the North Bosque River with mapped Holocene alluvium include the South Bosque, East Bosque, and Middle Bosque Rivers and Green, Duffau, Meridian, Neils, and Hog Creeks (Brown et al. 1972; Proctor et al. 1970).

The Little River is formed from the confluence of the Leon and Lampasas Rivers and flows southeast across Bell County of the Waco District before exiting the study area. The Holocene floodplain of the Little River is ca. $3 \mathrm{~km}$ wide and bordered by large segmented Pleistocene terraces along most of its course (Proctor et al. 1981). Near its confluence with the Brazos, the Little River's floodplain is $5-6 \mathrm{~km}$ wide. Tributaries of the Little River flow east, northeast, and southeast across the southern part of the Waco District (Proctor et al. 1981). The largest tributary, the San Gabriel River, has a Holocene floodplain up to ca. $0.2 \mathrm{~km}$ in width that is flanked by segmented Pleistocene terraces. Other tributaries with mapped alluvium include Knob, Darrs, Donahoe, Big Elm, Sandy, and Pin Oak Creeks (Proctor et al. 1981).

The Leon River heads in Eastland County of the Brownwood District and flows southeast across Comanche County to enter the Waco District at Hamilton County. From here it continues southeast across Coryell and Bell Counties (Kier et al. 1976; Proctor et al. 1970). It merges with the Lampasas River in Bell County to form the Little River. The Holocene floodplain of the Leon is ca. $1 \mathrm{~km}$ wide and bound by Pleistocene terrace segments or the bedrock valley wall. Tributaries of the Leon River with mapped alluvium in the Brownwood and Fort Worth Districts include the Sabana River and Indian,
Resley, Holmsley, South Leon, Warren, Copperas, and Armstrong Creeks. (Kier et al. 1976; Brown et al. 1972). Tributaries with mapped alluvium in the Waco District include Plum, Coryell, Henson, Owl, and Cowhouse Creeks (Proctor et al. 1970).

The Lampasas River begins in Mills County of the Brownwood District and Hamilton County of the Waco District and flows southeast through both districts. It then flows east and northeast across Bell County where it merges with the Leon River to form the Little River. The Lampasas River has a relatively narrow Holocene floodplain averaging less than $1 \mathrm{~km}$ in width (Kier et al. 1976; Proctor et al. 1981). Small Pleistocene terrace remnants flank the floodplain along some segments of the river. Tributaries of the Lampasas River with mapped alluvium in the Brownwood District include Bennett, Simms, School, Lucy, Sulphur, and Mesquite Creeks (Kier et al. 1976). Tributaries with mapped alluvium within the Waco District include Rocky and Salado Creeks (Proctor et al. 1981).

The Navasota River begins in Hill County and flows southeast across Hill and Limestone Counties of the eastern Waco District. Small remnant Pleistocene terraces flank the floodplain, becoming larger and more common along the river's lower course south of the study area. Larger tributaries of the Navasota River with mapped Holocene alluvium in the Waco District include Christmas, Steele, Faulkenberry, Blummers, Big, and Sanders Creeks (Proctor et al. 1970).

Several smaller tributaries with mapped Holocene alluvium enter the lower course of the Brazos River from the City of Waco to the southern boudary of the study area and include Tehuacana Creek, Cow Bayou, and Deer Creek (Proctor et al. 1970).

Headwater tributaries of the Colorado River begin west and northwest of the four-district area, coming together in Borden County of the Abilene District. It flows east and then southeast across Borden, Scurry, and Mitchell Counties of the Abilene District before it exits the study area. The Colorado River reenters the fourdistrict area in Coleman County of the Brownwood District, flowing eastward and then southeastward across the district.

In the headwaters area of Borden County, the Colorado River Holocene floodplain is 1.0 to 
$1.5 \mathrm{~km}$ wide, lacking higher Pleistocene terraces (Eifler et al. 1974). To the southeast in Mitchell County (Abilene District), the Holocene floodplain narrows and large segmented Pleistocene terraces border the Colorado. Tributaries of the Colorado River along this stretch of its course with mapped Holocene alluvium include Beals Branch, Big Silver, Bull, Gold, Grape, Kate, Red Bank, Rose, Wildcat, Wildhorse, and Willow Creeks.

The Holocene floodplain of the Colorado River is less than $1 \mathrm{~km}$ wide as it reenters the study area and flows across the Brownwood District (Barnes and Rose 1981; Kier et al. 1976; Proctor et al. 1981). Along some portions of this stretch, Holocene deposits are not even mapped or lie under the conservation pools of the highland lakes. Pleistocene terraces are mapped along the western portions of this stretch of the Colorado but are nearly absent as the river flows through the narrow valleys and canyons of the Llano Uplift and Balcones Canyonlands. This portion of the Colorado River, from Coleman County to the City of Austin, has many tributaries with mapped Holocene alluvium. Within the Brownwood District, these include Antelope, Bluff, Bull, Cherokee, Clear, Cow, Corn, Deep, Elliot, Elm, Home, Nabors, Panther, Saddle, and Salt Creeks (Kier et al. 1976).

One large tributary, Pecan Bayou, merges with the Colorado River along this segment of its course. Pecan Bayou begins in Callahan County of the Abilene District and flows southeast across the Abilene and Brownwood Districts to meet the Colorado River in Mills County. The Pecan Bayou floodplain ranges from less than $1 \mathrm{~km}$ to almost $3 \mathrm{~km}$ wide (Brown et al. 1972; Kier et al. 1976). Pleistocene terrace segments flank portions of the floodplain but are rare. In the Abilene District, tributaries to Pecan Bayou displaying mapped Holocene alluvium include Middle Fork Pecan Bayou, Clear Fork Pecan Bayou, and Crooked Creek (Brown et al. 1972). In the Brownwood District, tributaries displaying mapped Holocene alluvium include Red River and Blanket, Brown, Doudle, Greenbriar, Hog, Jim Ned, Little Pecan, Mullin, Pompey, Salt, Steppe, and Willis Creeks (Brown et al. 1972; Kier et al. 1976).

\section{Paleoenvironments}

Paleoenvironmental data are basic for understanding the nature of prehistoric human adaptations. Such data not only provide an understanding of the environmental contexts in which cultures existed, but may also provide an understanding of the natural processes responsible for the formation and preservation of the archeological record. A variety of proxy evidence-such as pollen records, isotopic chemistry, depositional records, and fossil vertebrate remains - is used to interpret past environments and climates. Overall, these data indicate that the late Quaternary environment of the region has been dynamic, witnessing shifts between cooler and warmer, and wetter and drier periods.

At the peak of the Last Glacial Maximum (ca. 18,000 years ago), Texas was much cooler and wetter than it is today. Vertebrate faunal and pollen records from central Texas suggest summer temperatures were at least $5^{\circ} \mathrm{C}$ cooler than those of today and effective moisture was considerably higher (Toomey et al. 1993:305, 311). Pollen records from Bonfire Shelter in Val Verde County suggest more-mesic conditions prevailed and that a landscape mosaic of woodlands, parklands, and grasslands was in place during the late Pleistocene in the Lower Pecos region (Bryant and Shafer 1977:10). Pollen data from Boriack Bog in Lee County suggest a woodland environment was in place between 16,500 and 12,500 B.P. (Bousman 1994:79), while pollen from Patschke Bog nearby point to cool grassland conditions between 17,000 and 15,500 B.P. (Mauldin et al. 2003:13). The beginning of a gradual warming trend at ca. 15,000 B.P. is interpreted by Holloway and Bryant (1984) based on a decrease in spruce pollen in the Boriack Bog pollen record. Toomey et al. (1993:306) note that mean summer temperatures were within $2-3^{\circ} \mathrm{C}$ of modern values by ca. 13,000 B.P. Stable oxygen isotope ratios from pedogenic carbonates and freshwater marls in southern Texas also suggest a warming trend toward the end of the Pleistocene (Bousman 1992; Bousman et al. 1990). In addition, stable carbon isotope analysis of soil organics at the Fort Hood Military Reservation in central Texas reveals a gradual increase in $\mathrm{C}$ plants (warm-season grasses) between 11,000 and 8000 B.P., which Nordt et al. (1994) interpret as a shift to warmer and drier climatic conditions.

Between ca. 10,000 and 7000 years ago, the late Pleistocene plant communities of the Lower Pecos region were gradually replaced by expand- 
ing scrub grasslands, as suggested by decreases in pine pollen and increases in grass pollen (Bryant and Holloway 1985:57). In central Texas, brief oscillations between grasslands and woodlands occurred between 12,500 and 7500 B.P. (Bousman 1994:80). Although there is not complete correspondence, Toomey et al. (1993:306) note fluctuations between moist and dry periods based on vertebrate faunal remains recovered from Hall's Cave on the Edwards Plateau between 14,000 and 10,500 B.P. Both Bousman (1994:80) and Toomey et al. (1993:306) suggest that the drier intervals $(12,500-11,800$ B.P. [Bousman 1994] and 12,500-10,500 B.P. [Toomey et al. 1993]) may be a response to increased meltwater discharge into the Gulf of Mexico (Broecker et al. 1988; Fairbanks 1989), effectively decreasing surface water temperatures, evaporation rates, and subsequent inland transport of Gulf moisture.

An expansion of grasslands occurred by 7500 B.P., as inferred from a dramatic increase in grass pollen in the Boriack Bog record (Bousman 1994:80). Grassland environments were dominant from 7000 to 4000 B.P. based on pollen records from Boriack, Patschke, and Weakly Bogs in east-central Texas (Bousman 1998:210; Mauldin et al. 2003:15). In central Texas, stable carbon isotope ratios reveal that mixed $\mathrm{C}_{3} / \mathrm{C}_{4}$ plant communities were almost completely replaced by $\mathrm{C}_{4}$-dominant plant communities between 6000 and 5000 B.P. (Nordt et al. 1994:117). At this time, upland soil mantles in central Texas were severely stripped (Kibler 1999; Toomey et al. 1993:309). Toomey et al. (1993:309) note that the influx of sediment into Hall's Cave increased by a factor of two after 8000 B.P. Other areas of Texas experienced severe drought conditions, which many have interpreted as a manifestation of Antevs's (1948) Altithermal (e.g., Holliday 1989; Meltzer 1991). The previously mentioned region-wide downcutting of stream channels between 7000 and 5000 B.P. is probably a response to the severe middle Holocene drought conditions. It should be noted that not all concur with the midHolocene timing of peak warm and xeric conditions. Toomey et al. (1993:309) believe the gradual warming and drying trend that commenced at the end of the Pleistocene culminated between ca. 5000 and 2500 B.P. based on the de- mise of certain environmentally sensitive species. Different yet is the interpretation of Johnson and Goode (1994), who see no gradual post-Pleistocene drying and warming trend, but a sudden shift to more-xeric conditions at ca. 4250-2550 B.P. Regardless, more-mesic conditions returned in the late Holocene.

The return to moister conditions is inferred from increases in arboreal pollen in the Boriack Bog record after 5000 B.P. (Bousman 1994:80). Nordt et al. (1994:118) interpret a similar shift to cooler and wetter conditions at ca. 4000 B.P., as the abundance of $\mathrm{C}_{4}$ plant biomass decreased. Faunal remains from Hall's Cave also indicate a return to more-mesic conditions by ca. 2500 B.P. (Toomey et al. 1993:310). Other parts of Texas also experienced a shift to more-mesic conditions in the late Holocene. Carbon isotope ratios of soil humates from southern Texas depict an environment dominated by $\mathrm{C}_{3}$ plants (Bousman et al. 1990:94-95). The pollen record for the Lower Pecos region indicates the occurrence of a mesic interval at ca. 2500 B.P., as suggested by increases in pine and grass pollen at Bonfire Shelter and the Devil's Mouth site (Bryant and Larson 1968).

Climatic conditions over the last 2,000 years have varied and appear to have oscillated between moist and dry periods, but concurrence on the timing of these shifts and intervals is tenuous. Nordt et al. (1994:117) note a slight but brief increase in $\mathrm{C}_{4}$ plant biomass at ca. 2000 B.P. Bousman (1998:216) interprets spikes in grass pollen in the Weakly Bog record at 1500 and 500 300 B.P. as representative of drier climatic intervals. Floodplain stabilization and subsequent soil formation throughout the Leon River drainage basin at Fort Hood at ca. $1300-1000$ B.P. are interpreted as indicating a shift to drier conditions (Mehalchick et al. 2000). Other lines of evidence, such as channel entrenchment, lower local water tables, expansion of grasslands, and increased eolian activity, suggest that at ca. 1000 B.P. climatic conditions became increasingly arid across central Texas, as well as other parts of Texas (Blum and Valastro 1989; Frederick 1998; Hall 1982, 1988, 1990; Holliday 1985; Huebner 1991; Kibler 1998). Toomey et al. (1993:315) characterize the climatic conditions of the last 1,000 years as being prone to frequent short-term droughts. 



\section{SYNOPSIS OF NATIVE AMERICAN CULTURE HISTORY}

The following culture history summaries divide the study region into four areas based on an amalgam of environmental and cultural characteristics (Figure 3). Some of these areas are more coherent as cultural regions, but others with less well-defined culture histories are based more on natural environments. Other differences between the sections arise from the fact that the archeology of some of these areas has been synthesized to a substantial extent in recent publications, but this is not the case in other areas. Hence, some summaries deal with the broad sweep of cultural developments, and others focus on recounting what has been learned from investigations at particular sites within a given area. No summary coincides precisely with a TxDOT district, and in most cases it has been necessary to use archeological information from multiple districts, including some outside the current study area, to construct summaries that make sense.

\section{CENTRAL BLACKLAND PRAIRIE}

\section{Previous Research}

The archeology of the central Blackland Prairie is not well understood because few largescale projects involving excavations at numerous sites have been undertaken. But enough archeological work has been done on the northern, eastern, and southeastern margins of the Waco District to provide some insights into the culture history of this area. Among the projects that have contributed important information are Navarro Mills Reservoir and Aquilla Lake in Hill County (Brown 1987; Duffield 1963), the Superconducting Super Collider and Bardwell Lake in Ellis County (Sorrow 1966; Yedlowski et al.
1998), and the State Highway 36-Little River project in Milam County (Gadus et al. 2006; Mahoney et al. 2003).

Several important investigations have been undertaken on or adjacent to the Blackland Prairie just south of the current study area in the eastern part of the Austin District, particularly the work at Granger Lake in Williamson County (Bond 1978; Hays 1982; Prewitt 1974, 1982), the Bessie Kruze site in Williamson County (Johnson 2000), Rice's Crossing in Williamson County (Brownlow 2003), and the as-yet-unreported Rowe Valley site in Williamson County. As Johnson's (2000) excellent summary notes, however, the archeology of this part of the Blackland Prairie has more in common with that of the Edwards Plateau and central Texas to the west (as described below under Northern and Northeastern Central Texas). Hence, the discussion below focuses on the rest of the central Blackland Prairie.

\section{Paleoindian Period}

Sites such as Horn Shelter No. 2 and Wilson-Leonard have provided substantial information on the Paleoindian period for the area to the west of this region, but there are no excavated and reported Paleoindian components on the central Blackland Prairie. Nonetheless, a variety of early points have been found, largely in surface contexts, and it is clear that this part of Texas was used throughout the Paleoindian period (ca. 11,500-8800 B.P.). Presumably, low population densities and high residential mobility characterized these early hunter-gatherer groups. Paleoindian materials from the region include several San Patrice or Brazos Fishtail and Plainview points from Aquilla Lake (Brown 


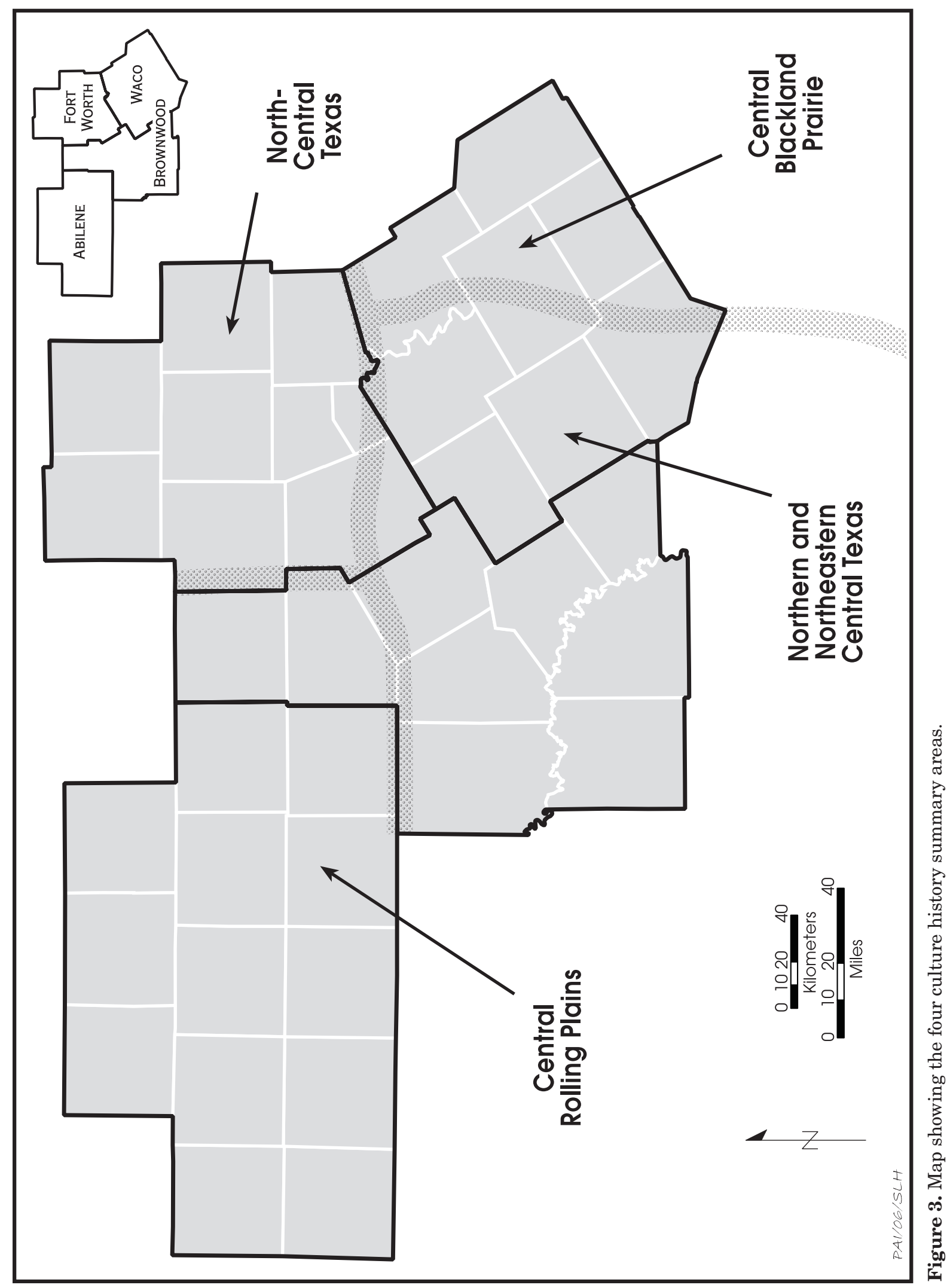


1987:44-1 through 44-2); a handful of points typed as Clovis, Dalton, Golondrina, Plainview, and San Patrice, along with several untyped lanceolate specimens, in collections by C. K. Chandler and other avocational archeologists from sites mostly in Ellis County (Yedlowski et al. 1998:519-520); a cache of 23 prismatic blades from a site in Navarro County (Young and Collins 1989); and probably the Brookeen Creek cache of 173 blades and flakes from Hill County (Mallouf 1981).

\section{Archaic Period}

Some excavated sites in the region have components dating to the Archaic period (ca. $8800-1250$ B.P.), but materials dating to the early and middle parts of the period are not very abundant. A variety of projectile point styles traditionally associated with the Early and Middle Archaic periods of central Texassuch as Andice, Angostura, Bell, Gower, Hoxie, Martindale, Nolan, Travis, and Uvalde-were identified in private artifact collections analyzed for the Superconducting Super Collider project just to the north in Ellis County (Yedlowski et al. 1998:520). These points are few in number, however, and do not appear to represent major occupations of this part of the Blackland Prairie. Unequivocal early point styles were even scarcer at the nearby Pecan Springs site at Bardswell Reservoir and the Strawn Creek site at Navarro Mills Reservoir, with a Hoxie point from Pecan Springs being the clearest example (Duffield 1963; Sorrow 1966). Similarly, Early to Middle Archaic points-including Angostura, Bell/Andice, Gower, Hoxie (?), and Martindale-were found only in small numbers at Aquilla Lake (Brown 1987:44-12 through 44-21), suggesting limited use of the valleys of Aquilla and Hackberry Creeks during this time. Given the limited information available for this part of the period, it is difficult to say much about subsistence and settlement patterns. It does appear, however, that the region was used in a limited fashion, presumably reflecting low population densities among mobile hunter-gatherers.

A different picture is presented for the latter part of the Archaic period-that is, after about 4000 B.P.--in that more-intensive occupation is suggested. Both the Pecan Springs and Strawn Creek sites yielded such Late Archaic point types as Dawson, Gary, and Yarbrough, although they tended to be mixed with materials from later occupations (Duffield 1963:60-62; Sorrow 1966:56-61). The surface collections analyzed during the Superconducting Super Collider project also contained these types, as well other Late Archaic types common to central Texas-such as Bulverde, Darl, Ensor, Marcos, Marshall, Montell, and Pedernales_-and a variety of probable Late Archaic forms more characteristic of north-central and eastern Texas, such as Carrollton, Edgewood, Elam, Ellis, Kent, and Neches River (Yedlowski et al. 1998:520-521). Noting the relatively high frequency of Late Archaic projectile points, Yedlowski et al. (1998:527-528, 533) suggest that the region saw an increase in use by hunter-gatherers. They also note that, although the projectile point evidence indicates interaction with groups living in central Texas proper, larger proportions of points indicate affinities with eastern Texas than during the Early and Middle Archaic. Brown (1987:44-22 through 44-26) presents similar conclusions concerning an increase in occupational intensity (increased population?) and increased interaction to the north and east during the Late Archaic for the Aquilla Lake area based on an increase in the number of sites with Late Archaic diagnostics and the dominance of the Gary dart point type.

Site 41MM340 on the Little River just beyond the southeast edge of the Waco District presents a somewhat different picture (Mahoney et al. 2003). It contains a Late Archaic component dating mostly to about 1400 to 400 B.C. Most of the dart points belong to types that firmly tie the region to central Texas to the west at this time, including Darl, Ensor, Godley, Marcos, Marshall, and especially Pedernales. Some more-eastern types, such as Gary, Kent, and Yarbrough, are represented, however. This site contained numerous hearth features represented by both burned rock clusters and charcoal and burned clay concentrations. Subsistence data indicate that the hunter-gatherers who occupied the Little River valley at this time consumed the meat of a variety of fauna, including mussels, deer, bison, turtles, beavers, rabbits, raccoons, opossum, skunks, turkeys, ducks, and fish. Botanical remains were not as abundant, although nutshell fragments indicate that hickory and pecan nuts were part of the diet. 
Archeological Impact Evaluations and Surveys

\section{Late Prehistoric Period}

Sites dating to the Late Prehistoric period, after ca. 1250 B.P., also are relatively common. The collections analyzed during the Superconducting Super Collider project contain substantial numbers of both early (e.g., Alba, Bonham, Catahoula, Colbert, Scallorn, and Steiner) and late (e.g., Cliffton and Perdiz) arrow points, but Yedlowski et al. (1998:521, 527) note that early arrow points are more frequent, perhaps reflecting continued high population densities from the Late Archaic period. Other than the Perdiz and Scallorn types, which have such widespread distributions, the arrow point styles suggest strong ties to the east and north. The limited ceramic samples, containing sherds reminiscent of types such as Killough Pinched, Maydelle Incised, Poyner Engraved, and Weches Fingernail Impressed, also support interaction with Caddoan groups to the east (Yedlowski et al. 1998:521522). The Strawn Creek site presents a similar picture, with most of the typed arrow points dating to the first half of the Late Prehistoric period and the more-distinctive ceramics in the small collection relating to the early Caddoan types Crockett Curvilinear Incised and Weches Fingernail Impressed (Duffield 1963).

Occupations dating to the early and late parts of the Late Prehistoric period also are represented at Aquilla Lake at the western edge of the Blackland Prairie, with the strongest components at the McDonald and Brazil sites (Brown 1987:44-27). Almost all of the small ceramic sample was from one site, McDonald. Among the ceramics are specimens that could be related to the Caddoan types Canton Incised, Kiam Incised, and Maydelle Incised, pointing to interaction with groups living to the east and northeast. The faunal sample from the McDonald site indicates that these hunter-gatherers relied on deer, turtles, fish, and mussels; bison were used only during the latter part of the period (Brown 1987:38-144).

Recent excavations at the J. B. White site on the Little River in Milam County near the southeast edge of the Waco District have shed new light on Late Prehistoric use of this part of the Blackland Prairie (Gadus et al. 2006). The excavations focused on broad exposure of the remains of a series of Late Prehistoric occupations dating from to A.D. 800 or 900 to 1300 , with morelimited sampling of a component dating to the
A.D. $600-700$ s. Analysis of the data recovered indicates that $41 \mathrm{MM} 341$ was a campsite occupied perhaps mostly during the summer months by local hunter-gatherers who took mussels and fish from the river and hunted a variety of game, especially deer, on the Little River floodplain and the surrounding uplands. They may have used botanical resources less, although they did consume hardwood nuts and wild onion and false garlic bulbs. One important activity performed at the site was manufacture of stone tools, mostly arrow points (Alba, Perdiz, and Scallorn), Friday and Gahagan knives, and expedient flake tools, using chert collected from gravel bars in the river. Many of these tools were used in the wide variety of procurement, processing, and manufacturing activities that typified daily life at $41 \mathrm{MM} 341$, but some appear to have been made because they would be needed later in the year after people left the site. One anticipated need was for trade with the Caddo Indians of east Texas. The people who lived at 41MM341 and other sites in the Little River valley interacted regularly with the Caddo, perhaps in trade relationships that helped cement cooperative alliances aimed at regulating competition among groups. Unlike in some other parts of the region, though, this trade did not result in local groups acquiring ceramic vessels from the Caddo, at least in appreciable numbers.

\section{Historic Period}

There is ample historical and archeological evidence of Native American use of at least the margins of the central Blackland Prairie during the protohistoric and early historic periods. The Spanish located three missions (San Francisco Xavier de Horcasitas, San Ildefonso, and Nuestra Señora de la Candelaria) and a presidio (San Francisco Xavier de Gigedo) near the confluence of Brushy Creek and the San Gabriel River in Milam County in the late 1740s and early 1750s in response to requests from immigrant Ervipiame, Deadose, Mayeye, and Yojuane (Gilmore 1996a, 1996b). Historical accounts place the Mayeye in the area southeast of Waco much earlier than this, by 1687, and the 2,000strong Ervipiame and associated groups, known as Ranchería Grande, were in the area of Milam County by 1716 (Newcomb 1993:24, 26). The Tonkawa also probably roamed the central Blackland Prairie during the eighteenth century, 
for they were documented in northwestern Limestone County in 1778 and elsewhere in the region (Newcomb 1993:27-28). Archeological evidence for Native American use of the area consists of a number of sites that have been associated with Wichita groups who moved southward into the region in the eighteenth century. Among these are the Vinson site in Limestone County (Smith 1993), as well as sites near Waco and Whitney Lake (see discussion of Northern and Northeastern Central Texas below).

\section{NORTHERN AND NORTHEASTERN CENTRAL TEXAS}

\section{Previous Research}

The archeological record of the central Texas region is known from decades of investigations at various stratified open-air sites and rockshelters. Traditionally, the central Texas archeological region has included the Llano Uplift, Lampasas Cut Plain, eastern Edwards Plateau and its highly dissected eastern margin, and adjacent prairie margin (e.g., Prewitt 1981; Suhm 1960), encompassing large portions of the Waco and Brownwood Districts as well as the Austin District to the south. In the Waco District, sites that have contributed important information include the Landslide site (Sorrow et al. 1967), the Youngsport site (Shafer 1963), the Gault site (Collins and Brown 2000), Kyle Rockshelter (Jelks 1962), and several sites at Fort Hood (see Kleinbach et al. 1999; Mehalchick et al. 1999, 2000) and Waco Lake (Scott et al. 2002; Story and Shafer 1965). These sites have contributed to a better understanding of the prehistory of central Texas, with projectile point styles from some of these sites suggesting influences and contacts to varying degrees over time with areas to the east and northeast (cf. Collins 1995; Johnson and Goode 1994).

To the west in the Brownwood District, sites that have contributed important information include the Finis Frost site (Green and Hester 1973), the McCann site (Preston 1969), and several sites $(41 \mathrm{CN} 19,41 \mathrm{CN} 27$, and 41CN95) at O. H. Ivie Reservoir in Coleman County (Lintz et al. 1993; Treece et al. 1993a, 1993b). Like some of the sites in the Waco District, some sites in the Brownwood District suggest influences and contacts to varying degrees over time with ar- eas outside central Texas, such as the High Plains to the west.

To the south and southeast in the Austin District, sites that have contributed important information include the Wilson-Leonard site (Collins 1998), the Sleeper site (Johnson 1991), the Loeve-Fox site (Prewitt 1982), the Barton and Mustang Branch sites along Onion Creek (Ricklis and Collins 1994), and Smith Rockshelter (Suhm 1957). As in the other two districts, some of the sites in the Austin District suggest influences and contacts to varying degrees over time with areas outside central Texas, such as the Lower Pecos and Gulf Coastal Plain (Collins 1995; Johnson and Goode 1994). For more-complete bibliographies concerning archeological work done in the central Texas region, see Black (1989), Collins (1995), and Johnson and Goode (1994).

\section{Paleoindian Period}

Paleoindian (11,500-8800 B.P.) occupations are represented by surficial and deeply buried sites, rockshelter sites, and isolated artifacts. The period often is described as having been characterized by small but highly mobile bands of foragers who were specialized hunters of Pleistocene megafauna. But a more accurate view of Paleoindian life probably includes the use of a much wider array of resources (Meltzer and Bever 1995:59), including small fauna and plant foods. Recent investigations at the WilsonLeonard site support this view and have challenged the fundamental defining criterion of the Paleoindian period, that of artifacts in association with late Pleistocene megafauna (Collins 1998). Additionally, longstanding ideas about aspects of Paleoindian technologies are being challenged.

Collins (1995) divides the Paleoindian period into early and late subperiods. Two projectile point styles, Clovis and Folsom, are included in the early subperiod. Clovis chipped stone artifact assemblages, including the diagnostic fluted lanceolate Clovis point, were produced by bifacial, flake, and prismatic-blade techniques on high-quality and oftentimes exotic lithic materials (Collins 1990). Along with chipped stone artifacts, Clovis assemblages include engraved stones, bone and ivory points, stone bolas, and ochre (Collins 1995:381; Collins et al. 1992). Clovis points are found evenly distributed along 
the eastern edge of the Edwards Plateau, where springs and outcrops of chert-bearing limestone are common (Meltzer and Bever 1995:58). Clovis, as well as a number of later Paleoindian dart points, have been recovered from the Gault site in Bell County (Collins and Brown 2000), the Triple S Ranch site in Hamilton County (Hatfield 1997), and San Macros Springs in Hays County (Takac 1991). Probable Clovis polyhedral blade cores have been found in Hamilton County, as well as a blade and blade core in Comanche County (Goode and Mallouf 1991; Green 1963). Analyses of Clovis artifacts and site types suggest that Clovis peoples were well-adapted, generalized hunter-gatherers with the technology to hunt larger game but not rely on it solely.

In contrast, Folsom tool kits-consisting of fluted Folsom points, thin unfluted (Midland) points, large thin bifaces, and end scrapers-are more indicative of specialized hunting, particularly of bison (Collins 1995:382). Folsom points have been recovered from Horn Shelter No. 2 along the Brazos River (Redder 1985; Watt 1978), and Folsom-age materials have been recovered from the Gault site. A Midland point was recovered from the Wilson-Leonard site.

Postdating Clovis and Folsom points in the archeological record are a series of dart point styles for which the temporal, technological, or cultural significance is unclear. Many of these dart point styles are unfluted and lanceolate. Often, the Plainview type name is assigned these lanceolate dart points, but Collins (1995:382) has noted that many of these points do not parallel Plainview type-site points in thinness and flaking technology. Investigations at the WilsonLeonard site (Collins 1998) and a statistical analysis of a large sample of unfluted lanceolate points by Kerr and Dial (1998) have shed some light on this issue. At Wilson-Leonard, the Paleoindian projectile point sequence includes an expanding-stem dart point termed Wilson, which dates to ca. 10,000-9500 B.P. Postdating the Wilson component is a series of unfluted lanceolate points referred to as Angostura, Golondrina-Barber, and St. Mary's Hall, but their chronological sequence is poorly understood. Several dart point styles were recovered from Horn Shelter No. 2, including Dalton, Plainview, San Patrice, and Scottsbluff (Watt's [1978] Brazos Fishtail points) types, but like many of the unfluted lanceolate points, the chronological position and cultural significance of Dalton and San Patrice dart points remain nebulous. Regardless, it has become clear that the artifact and feature assemblages of the later Paleoindian subperiod appear to be Archaic-like in nature and in many ways may represent a transition between the early Paleoindian and succeeding Archaic periods (Collins 1995:382).

\section{Archaic Period}

The Archaic period dates from ca. 8800 to 1300-1200 B.P. (Collins 1995). The Archaic period generally is believed to represent a shift toward the hunting and gathering of a wider array of animal and plant resources and a decrease in group mobility (Willey and Phillips 1958:107-108). In the eastern and southwestern United States and on the Great Plains, the Archaic period is succeeded by the development of horticultural-based, semisedentary to sedentary societies. In these areas, the Archaic truly represents a developmental stage of adaptation as Willey and Phillips (1958) defined it. For central Texas, this notion of the Archaic is somewhat problematic. An increasing amount of evidence suggests that Archaic-like adaptations were in place before the Archaic chronological period (see Collins 1995:381-382, 1998) and that these practices continued into the succeeding Late Prehistoric period (Collins 1995:385; Prewitt 1981:74; Treece et al. 1993b). Thus, in this region the Archaic period is not a developmental stage but an arbitrary chronological construct and projectile point style sequence. This sequence is based on several decades of archeological investigations at stratified Archaic sites along the eastern and southern margins of the Edwards Plateau. Collins (1995) and Johnson and Goode (1994) have divided this sequence into three parts-early, middle, and late-based on perceived (though not fully agreed on by all scholars) technological, environmental, and adaptive changes.

According to Weir (1976:115-122), Early Archaic (8800-6000 B.P.) sites are small and have diverse tool assemblages, suggesting that populations were highly mobile and densities low (Prewitt 1985:217). It has been noted that Early Archaic sites are concentrated along the eastern and southern margins of the Edwards Plateau (Johnson and Goode 1994; McKinney 1981). This distribution may indicate climatic conditions at the time, given that these areas have more reli- 
able water sources and a more-diverse resource base than other parts of the region. Early Archaic projectile point styles include Angostura, Gower, Hoxie, Martindale, Uvalde, and Wells. Manos, metates, hammerstones, Clear Fork and Guadalupe bifaces, and a variety of other bifacial and unifacial tools are common to Early Archaic assemblages. The construction and use of rock hearths and ovens, which saw limited use during late Paleoindian times, became commonplace. The use of rock features suggests that the retention of heat and its slow release over an extended period of time were an important aspect of food processing and cooking and reflects a specialized subsistence strategy. Such a practice probably was related to cooking plant foods, particularly roots and bulbs, many of which must be subjected to prolonged periods of cooking to render them consumable and digestible (Black et al. 1997:257; Wandsnider 1997; Wilson 1930). Botanical remains, as well as other organic materials, are often poorly preserved in Early Archaic sites, so the range of plant foods exploited and their level of importance in the overall subsistence strategy are poorly understood. But the recovery of charred wild hyacinth (Camassia scilloides) bulbs from an Early Archaic feature at the Wilson-Leonard site provides some insights into the types of plant foods used (Collins 1998). Significant Early Archaic sites include the Youngsport site in Bell County (Shafer 1963), which yielded Gower and Wells dart points from deeply buried contexts, and the Jetta Court site in Travis County (Wesolowsky et al. 1976).

During the Middle Archaic period (60004000 B.P.), the number and distribution of sites, as well as site size, increased because of probable increases in population densities (Prewitt 1981:73; Weir 1976:124, 135). Macrobands may have formed at least seasonally, or an increased number of small groups may have used the same sites for longer periods of time (Weir 1976:130 131). A greater reliance on plant foods is suggested by the presence of burned rock middens toward the end of the Middle Archaic, although tool kits still imply a strong reliance on hunting (Prewitt 1985:222-226). Middle Archaic projectile point styles include Andice, Baird, Bell, Nolan, Taylor, and Travis. Bell and Andice points reflect a shift in lithic technology from the preceding Early Archaic Martindale and Uvalde point styles (Collins 1995:384). Johnson and Goode (1994:25) suggest that the Bell and Andice darts are parts of a specialized bison-hunting tool kit. They also suggest that the beginning of the Middle Archaic was marked by an influx of bison and bison-hunting groups from the Eastern Woodland margins during a slightly moremesic period. Bell points and bison remains were recovered from the Landslide site in Bell County (Sorrow et al. 1967).

Bison disappeared, perhaps in response to the return of more-xeric conditions, during the later part of the Middle Archaic. Later Middle Archaic projectile point styles represent another shift in lithic technology (Collins 1995:384; Johnson and Goode 1994:27). Prewitt (personal communication 2000) postulates that Travis and Nolan points are similar in production and morphology to projectile points from the Lower Pecos region. Such characteristics as beveled stems and overall morphology may have originated in the Lower Pecos because these elements appeared earlier in the Lower Pecos than they did in central Texas. Shafer's (1963:67) surprise that Nolan points, which are more common in sites to the south and west, were not found in greater numbers at the Youngsport site might support the idea that bearers of these darts came out of the Lower Pecos and moved into adjacent portions of central Texas but did not use all portions of central Texas equally. Burned rock midden formation in the Middle Archaic probably reflects intensified use of a specific resource (geophytic or xerophytic plants) or resource patches, which resulted in the debris of multiple rock ovens and hearths accumulating as middens on stable to slowly aggrading surfaces, as suggested by Kelley and Campbell (1942) many years ago. Johnson and Goode (1994:26) believe that dry conditions promoted the spread of yuccas and sotols, and that these were the plants that were collected and cooked in large rock ovens by late Middle Archaic peoples.

During the succeeding Late Archaic period (4000 to 1300-1200 B.P.), populations continued to increase (Prewitt 1985:217), and the archeological record is more visible (Treece et al. 1993a:588). Within stratified Archaic sites—such as Youngsport, the Britton site in McLennan County (Story and Shafer 1965), the Steele site in Hill County (Stephenson 1970), and the LoeveFox site in Williamson County (Prewitt 1982) the Late Archaic components contain the densest concentrations of cultural materials. The establishment of large cemeteries along drainages 
suggests strong territorial ties by certain groups (Story 1985a:40). A variety of projectile point styles appeared throughout the Late Archaic period. Johnson and Goode (1994:29-35) divide the Late Archaic into two parts based on increased population densities and perceived evidence of Eastern Woodland ceremonial rituals and religious ideological influences.

Middle Archaic subsistence technology, including the use of rock and earth ovens, continued into the Late Archaic period. Collins (1995:384) states that, at the beginning of the Late Archaic period, the use of rock ovens and the resultant formation of burned rock middens reached its zenith and that the use of rock and earth ovens declined during the latter half of the Late Archaic. But there is mounting evidence that midden formation culminated much later and that this high level of rock- and earth-oven use continued into the early Late Prehistoric period (Black et al. 1997:270-284; Kleinbach et al. 1995:795). A picture of prevalent burned rock midden development in the eastern part of the central Texas region after 2000 B.P. is gradually becoming clear. This scenario parallels the widely recognized occurrence of post-2000 B.P. middens in the western reaches of the Edwards Plateau (see Goode 1991; Treece et al. 1993a). The use of rock and earth ovens for processing and cooking plant foods suggests that this technology was part of a generalized foraging strategy. The amount of energy involved in collecting plants, constructing hot-rock cooking appliances, and gathering fuel ranks most plant foods relatively low based on the resulting caloric return (Dering 1999). This suggests that plant foods were part of a broad-based diet (Kibler and Scott 2000:134) or part of a generalized foraging strategy, an idea put forth earlier by Prewitt (1981). But at times during the Late Archaic, this generalized foraging strategy appears to have been marked by shifts to a specialized economy focused on bison hunting (Kibler and Scott 2000:125-137). Castroville, Montell, and Marcos dart points are elements of tool kits often associated with bison hunting (Collins 1968). Archeological evidence of this association is seen at Bonfire Shelter in Val Verde County (Dibble and Lorrain 1968), Jonas Terrace (Johnson 1995), Oblate Rockshelter (Johnson et al. 1962:116), John Ischy (Sorrow 1969), and Panther Springs Creek (Black and McGraw 1985).

The Archaic period represents a hunting and gathering way of life that was successful and that remained virtually unchanged for more than 7,500 years. This notion is based in part on fairly consistent artifact and tool assemblages through time and localities and resource patches that were used continually for several millennia, as witnessed by the formation of burned rock middens. This pattern of generalized foraging, though marked by brief shifts to a heavy reliance on bison, continued almost unchanged into the succeeding Late Prehistoric period.

\section{Late Prehistoric Period}

The Late Prehistoric period (1300-1200 to 300 B.P.) was marked by the introduction of the bow and arrow and, later, ceramics into central Texas. Population densities dropped considerably from their Late Archaic peak (Prewitt 1985:217). Subsistence strategies did not differ greatly from the preceding period, although bison again became an important economic resource during the late part of the Late Prehistoric period (Prewitt 1981:74). The use of rock and earth ovens for plant food processing and the subsequent development of burned rock middens continued throughout the Late Prehistoric period (Black et al. 1997; Kleinbach et al. 1995:795; Treece at al. 1993a). Horticulture came into play very late in the region but was of minor importance to overall subsistence strategies (Collins 1995:385).

In central Texas, the Late Prehistoric period generally is associated with the Austin and Toyah phases (Jelks 1962; Prewitt 1981:82-84), though Story (1990:364) argues for a period or horizon characterized by Alba points and early Caddoan-like pottery intermediate between the Austin and Toyah phases for the middle Brazos River basin. Evidence of this proposed archeological manifestation was found at the Chupik site in McLennan County (Watt 1953). There is also evidence from the Colorado River basin indicating that Garza Complex peoples of the High Plains escarpment area frequented the morewestern portions of the region during Toyah times (Treece et al. 1993b). Exotic materials, such as ceramics and obsidian, from areas farther west in the Trans-Pecos and New Mexico are common in this part of the region. For the most part, however, the Late Prehistoric period of the region is dominated by the Austin and Toyah phases. 
Much of what is known about the Austin and Toyah phases comes from rockshelters in and around Whitney Lake in Bosque and Hill Counties (see Jelks 1962; Stephenson 1970), though Austin and Toyah phase horizon markersScallorn-Edwards arrow points for Austin and Perdiz arrow points for Toyah-are distributed across most of the state. The introduction of Scallorn and Edwards arrow points into central Texas often was marked by evidence of violence and conflict, as many excavated burials contain these point tips in contexts indicating they were the cause of death (Prewitt 1981:83). Subsistence strategies and technologies (other than arrow points) did not change much from the preceding Late Archaic period. This continuity is recognized by Prewitt's (1981) use of the term "Neoarchaic." In fact, Johnson and Goode (1994:39-40) and Collins (1995:385) state that the break between the Late Archaic and the Late Prehistoric could be represented easily and appropriately by the break between the Austin and Toyah phases. Assemblages from sites like $41 \mathrm{CN} 19$ suggest that both upland and riparian environments were used and that a wide range of resources was exploited, though bison are notably absent from the assemblage (Treece et al. 1993a:562-563).

Around 1000-750 B.P., slightly more-xeric or drought-prone climatic conditions returned to the region, and bison returned in large numbers (Huebner 1991; Toomey et al. 1993). Using this vast resource, Toyah peoples were equipped with Perdiz point-tipped arrows, end scrapers, fourbeveled-edge knives, and plain bone-tempered ceramics. The technology and subsistence strategies of the Toyah phase represent a completely different tradition from the preceding Austin phase. Collins (1995:388) states that the formation of burned rock middens ceased because bison hunting and group mobility obtained a level of importance not witnessed since Folsom times. Although the importance of bison hunting and high group mobility hardly can be disputed, the cessation of burned rock midden development during the Toyah phase is tenuous. A recent examination of Toyah-age radiocarbon assays and assemblages by Black et al. (1997) suggests that their association with burned rock middens represents more than a "thin veneer" capping Archaic-age features. Black et al. (1997) claim that burned rock midden formation, although not as prevalent as in earlier periods, played a role in the adaptive strategies of Toyah peoples.

Contact between Toyah peoples and Caddoan groups to the east and northeast is represented by Caddoan ceramics in site assemblages, particularly in the eastern peripheral areas of central Texas (e.g., Ricklis and Collins 1994:305-311; Stephenson 1970). In more-western parts of the region, not only did contact with Garza Complex groups occur, but it also has been suggested that Toyah and Garza peoples used the region simultaneously (Treece et al. 1993b).

\section{Historic Period}

Historical accounts of Native Americans and their interactions with Europeans, the Republic of Mexico, the Texas Republic, and the United States throughout the region are provided by Campbell (1988), Foster (1995), Jelks (1970), Ricklis and Collins (1994), and Wade (1999). Much of the early available information on aboriginal groups comes from the late seventeenth and early eighteenth centuries, during which time the Spanish moved northward to establish missions on their northern frontier, and the French established a trading post near the Great Bend of the Red River and a short-lived colony along the central Texas coast. Although contact between Europeans and Native Americans became more permanent at this time, the disastrous disruptions of native social structures and economic systems by disease and oftentimes hostile encounters were already under way. Encroached on by the Spanish from the south and groups like the Apache from the north, many Native American groups sought refuge in the central Texas region. As a result, many groups that the Spanish encountered probably were not native to the region.

South of the study area, Campbell (1988) identifies the Cantona and Catqueza as two probable groups native to the region, but he also identifies groups from the Trans-Pecos and northeastern Mexico-such as the Jumano, Cíbola, Mescal, and Simaomo-within central Texas. Many of the groups encountered by the Spanish in this area were not socially or politically autonomous and often shared encampments, such as the large camp along the San Marcos River witnessed by the Terán de los Ríos expedition in 1691 (Foster 1995:57-58). It appears that these fusions of groups, which at times included the Hasinai Caddo, often occurred 
seasonally and were linked to bison hunting.

In the northern part of the study area, Wichita-speaking groups consisting of the Tawakoni, Waco, and Kichai; Caddoan tribes comprised of the Anadarko, Hasinai, and Kadohadacho; and the Tonkawa occupied the area historically. Many of these groups migrated into the area early in the Historic period. The ancestral Tonkawa moved in probably from north-central Oklahoma in the seventeenth century (Campbell 1988:75; Newcomb 1993:27). At the same time, Wichita groups were also moving into northern Texas (Newcomb 1993). Athanase de Mézières's expeditions along the Brazos River in the 1770s encountered two large Tawakoni villages along a stretch from presentday Waco to the vicinity of the Nolan River (Jelks 1970; Krieger 1996). Based on archeological evidence and historical documents, the Stansbury site near Whitney Lake was occupied by the Tawakoni in the 1770s-1780s (Jelks 1970), and Story (1985b) identifies a number of other sites (e.g., Gas Plant, Stone, and Walton) in the Waco area that appear to be associated with occupations by Wichita groups. By this time, Native American populations were decimated, and many groups lost their ethnic identity as they were forced into conglomerations of groups for defense or into the Spanish missions by the southward-moving Apaches and later Comanches. The Apaches, and especially the Comanches, dominated the landscape by the early 1800 s, raiding other Native American groups and the ever-increasing number of EuroAmerican settlements. By the 1870s, the remaining groups of Tonkawa, Apache, and Comanches were removed from the area and placed on reservations in Indian territory.

Historically, Apaches and later the Kiowa and Comanches occupied the western part of the study area (Leffler 1996a, 1996b). By the late eighteenth century, Comanches of the Penateka band had complete control of the area, but as in other areas, the Comanches were removed and placed on reservations by the 1870 s.

\section{NORTH-CENTRAL TEXAS}

\section{Previous Research}

This synopsis deals with most of the Fort Worth District and adjacent areas. Previous archeological investigations within this region vary in intensity and quality. Much work has been done in the Trinity River drainage, whereas significantly less work has taken place in the western and southwestern parts. For instance, on the East Fork of the Trinity River east of the Fort Worth District, several projects have made significant contributions, including Lavon Lake (Dawson and Sullivan 1973; Lynott 1975; Stephenson 1949) and Lake Ray Hubbard (Harris and Suhm 1963; Lorrain and Hoffrichter 1968; Ross 1966). Significant archeological projects on the upper Elm Fork of the Trinity in the Dallas-Fort Worth-Denton area include Ray Roberts Reservoir (Ferring 2001; Ferring and Yates 1997; Prikryl and Yates 1987; Skinner et al. 1982), Lewisville Lake (Brown and Lebo 1991; Ferring and Yates 1998; Stephenson 1950), and Grapevine Lake (Ferring 1975; Morgan 1975). Along the West Fork of the Trinity River and its tributaries, intensive investigations have occurred at Mountain Creek Lake (Peter and McGregor 1988). Investigations in the Brazos River basin as it passes through the southwestern part of the Fort Worth District include those at Lake Granbury (Skinner 1971) and Possum Kingdom Lake (Brayshaw 1970; Hughes 1942; Krieger 1946).

Much of the information generated by the reservoir investigations has yet to be synthesized. The following discussion of the prehistory of north-central Texas draws on the few synthetic and summary sources available, especially those by Prikryl (1990, 1993). Story's (1990) summary of archeology on the east Texas Gulf coastal plain also draws on some of the work done in the upper Trinity basin, and Lynott's (1981) discussion of prehistoric adaptations in the Cross Timbers, Grand Prairie, and Rolling Plains provides connections to an overview by Hofman et al. (1989) of southern Great Plains archeology.

\section{Paleoindian Period}

As with many other areas of Texas, Paleoindian materials in north-central Texas often are found in surface contexts or mixed with later materials. The generally low density of Paleoindian artifacts and sites and the tendency for projectile points to be made from nonlocal lithics have led investigators to characterize these populations as highly mobile with low regional densities (Lynott 1981:100-101). Megafauna fossil finds within the region have 
led some investigators to conclude that subsistence practices of Paleoindian peoples were linked to mammoth and bison. But no kill or butchering sites similar to those identified for the Southern Plains have ever been discovered (Prikryl 1990, 1993).

Generally, the Paleoindian period in northcentral Texas is considered to extend from ca. 10,000 to 6500 B.C. (Prikryl 1993:199). Point types often found that can be associated with the early to late parts of the period include Clovis, Dalton, Folsom, Plainview, San Patrice, and Scottsbluff. The most common types recognized are Dalton and Plainview (Prikryl 1990). Most of the recorded Paleoindian sites cluster in the upper Trinity drainage where the most intensive archeological investigations have taken place, though often these sites consist of no more than one or two points. But the Acton site, in Hood County situated on a $\mathrm{T}_{2}$ terrace of the Brazos River overlooking Lake Granbury, is significant for the number of Plainview and Dalton (Meserve) points it produced $(n=72)$. A variety of other lithic tools such as gouges, scrapers, and burins also were recovered. Unfortunately, the Paleoindian occupation could not be isolated from Archaic-period occupations of the site.

Interestingly, the only two investigated sites in north-central Texas with apparently discrete Paleoindian components are early; both produced Clovis projectile points. These sites are the Lewisville and Aubrey sites situated just east of the northern part of the Fort Worth District. The Lewisville site contained 27 hearth features with an associated Clovis point and other sparse lithics in a near-surface context (Crook and Harris 1957, 1958; Story 1990:182-184), and the Aubrey site contained a Clovis component with cultural features and concentrations of lithics and animal bones buried 7-9 m deep on the Elm Fork floodplain (Ferring 2001). Both sites also contained a variety of faunal remains both large and small, although only small game, the largest being white-tailed deer, can be associated comfortably with the Clovis occupation at the Lewisville site. Bison bones were recovered from Aubrey, but the preponderance of smaller game suggests a more-generalized pattern of foraging as opposed to the reliance on mammoth and bison apparently demonstrated at Clovis sites on the Southern Plains (Hofman et al. 1989:31-32). Such a divergence in subsistence patterns may reflect an inherent adaptability of Clovis tech- nology to changing environmental conditions encountered as early populations spread southeastward into Texas (Ferring and Yates 1997).

\section{Archaic Period}

The Archaic period extends from ca. 6500 B.C. to A.D. 700 , with ca. 2,500-year segments often considered as early, middle and late divisions of the period (Prikryl 1993:199). Diagnostic artifacts are similar to those of adjacent regions, although developing a sound chronological sequence of diagnostic artifacts has proven difficult because many of the investigations have focused on surface manifestations. Prikryl (1990) suggests that Early Archaic projectile points include early split-stemmed varieties and possibly Angostura, and Middle Archaic points include basal-notched forms such as Andice, Bell, and Calf Creek along with Bulverde, Carrollton, Dawson, and Wells. Late Archaic point types reportedly include Castroville, Dallas, Edgewood, Elam, Ellis, Gary, Marshall, Palmillas, Trinity, and Yarbrough (Prikryl 1990). At one time, the Carrollton and Elam foci were defined to refer to the Middle and Late Archaic respectively (Crook and Harris 1952, 1954). But reevaluation of the type-site artifacts showed that the materials were mixed such that perpetuation of these foci provides little interpretive value (Hofman et al. 1989:57; Prikryl 1990:73-74). Some of this mixing and the generally low numbers of Early and Middle Archaic sites may be because of extensive erosion of midHolocene deposits. This type of erosion has been documented for the Brazos drainage immediately west of the Fort Worth District in Young, Stephens, and Throckmorton Counties (Ensor et al. 1992:303).

Though few isolable components have been analyzed for the various divisions of the Archaic period in north-central Texas, slowly increasing populations responding to warmer and drier environmental conditions have been postulated to explain the overall archeological record of the period (Lynott 1981:103-104; Story 1990:212). It is thought that these factors may have led Archaic populations of the Cross Timbers and prairie areas of north-central Texas to develop a diversified hunting and gathering economy based on bottomland resources of the rivers and major creeks, while populations on the Rolling Plains maintained a focus on bison hunting 
(Hofman et al. 1989:57-58). Projectile points were fashioned from local lithic materials suggesting that populations were less mobile than their Paleoindian predecessors. Less mobility also may suggest refinement of the diversified subsistence pattern to include scheduling of resource use within more-restricted areas. Evidence from Late Archaic sites at Mountain Creek Lake (Peter and McGregor 1988) and Ray Roberts Reservoir (Ferring and Yates 1997) indicates repeated site occupation by small groups, which could support the resource scheduling hypothesis. Still, even with refinement of resource use, evidence of dietary stress has been found on Late Archaic human skeletal materials (Ferring and Yates 1997:305; Gill-King 1987:103-104).

Human burials are common in the archeological record of the Late Archaic and Late Prehistoric periods of at least the eastern part of north-central Texas (Prikryl 1993). Some of these burials are associated with Wylie pit features, which are large man-made depressions measuring ca. $16 \mathrm{~m}$ in diameter and $2-4 \mathrm{~m}$ in depth. These features were first identified at a series of sites along the East Fork of the Trinity River and were considered an important trait of the Wylie focus (Harris and Suhm 1963; Stephenson 1952; Wilson 1946). Radiocarbon assays from pits at the Upper Rockwall and Sister Grove Creek sites in the area of Lavon Lake suggest that the pits and the Wylie focus were associated with the Late Prehistoric period (Lynott 1975:117; Ross 1966). Lynott (1977) widened the temporal span by incorporating a Late Archaic phase into the focus definition. Subsequent work on Wylie pits at Richland-Chambers Reservoir to the south confirmed their Late Archaic age (Bruseth and Martin 1987:165). But the wide range of artifact types associated with them and the long span of time represented made it clear that the Wylie focus was not a useful construct. Bruseth and Martin (1987:280-284), although discarding the focus as unusable, further supported Lynott's (1975) original interpretation of the pits as being associated with large-scale food processing. Their interpretation likens the pits to the burned rock middens of central Texas, with both representing group aggregations.

\section{Late Prehistoric Period}

Group aggregation and large-scale manipulation of subsistence resources, as represented by the Wylie pits and the human burials they contain, may indicate societal changes that continued through the Late Prehistoric period. Habitation structures indicating increased sedentism, at least in certain places and at certain times, have been found in some Late Prehistoric sites, along with cultigens such as corn and arrow points and ceramics indicating important technological changes. Also, there may be evidence of differential mortuary practices that could reflect a shift toward a hierarchical social structure (e.g., the distinction between burials placed inside and outside Wylie pits), although this evidence is nowhere near as strong as that for the Caddoan area of northeast Texas. Prikryl $(1990,1993)$ defines two chronological periods for the Late Prehistoric in north-central Texas, which he links to particular projectile point and ceramic types.

Prikryl's (1990, 1993) Late Prehistoric I period (A.D. 700-1200) is marked by the arrow point types Alba, Bonham, Catahoula, Scallorn, and Steiner. Ceramic vessels are mostly grog tempered and undecorated, but there is some evidence of influences from other regions because some locally manufactured wares display designs similar to those associated with east Texas Caddo ceramic types. Evidence for corn and structures has been found at sites at Mountain Creek Lake southwest of Dallas, as well as to the north in Cooke County at Hubert Moss Lake near the Red River (Lorrain 1969; Martin 1994; Peter and McGregor 1988). Farther west, cultural changes also were taking place on the Rolling Plains, though this area held onto its Archaic lifestyle even after technological innovations such as the bow and arrow were accepted (Lynott 1981:106).

During the Late Prehistoric II period (A.D. 1200-1700), influences from the Southern Plains became pronounced in the Cross Timbers and prairie areas. These influences coincided with an increase in bison herd size in north-central Texas (Lynott 1981:106; Prikryl 1990:80). Bison were important to subsistence (Harris and Harris 1970; Morris and Morris 1970), but shrinking procurement territory sizes because of population increases continued the trend toward horticulture and settled village life. In terms of technology, a Plains Indian tool assemblage was common (Prikryl 1990:80). Items associated with this assemblage include calcareous-tempered ceramic vessels, some of 
which fit the description for the type Nocona Plain (shell tempered), and unstemmed triangular arrow points such as Fresno, Harrell, Maud, and Washita, as well as Perdiz points. Tools specific to bison processing include snubnosed or thumbnail scrapers and edge-beveled Harahey knives. Bison scapula hoes, which also are common in Plains Indian sites, have been recovered from sites in the Lewisville Lake and Lavon Lake areas of Denton and Collin Counties (Barber 1969:118-119; Harris 1945).

The Plains Indian influences associated with settled village life were used to define the Henrietta complex of north-central Texas. This complex, based on Krieger's (1946) more-expansive Henrietta focus, extends from the Red River south along the headwaters of the Trinity and Brazos Rivers. The type site, M. D. Harrell, is situated along the Brazos River in Young County just northwest of Palo Pinto County in the drainage basin for Possum Kingdom Reservoir (Krieger 1946). The Harrell site and other associated sites contain middens, house structures, rock hearths, storage pits, and burials, and they most often are found on sandy knolls or terraces overlooking river valleys (Brooks 1989:85-86; Forrester 1994:249-266). Excavated sites attributed to the Henrietta complex include the Coyote and Glass sites on the Red River in Montague County (Lorrain 1967:24-44; Woodall 1967a), and it is clear that sites such as Dillard in Cooke County are related as well (Martin 1994).

The Henrietta complex as an interpretive tool can be limiting because its loose definition tends to obscure local differences. More-recent investigations in the upper Trinity River drainage have tended to highlight the local differences. For instance, at Ray Roberts Reservoir Ferring and Yates (1997:305) see local trends emerging independent of extraregional influences. They cite the lack of evidence for extensive maize horticulture and the preponderance of short-term logistical camps as the basis of their hypothesis. Similarly, Peter and McGregor (1988:367) demonstrated that occupation of the Mountain Creek drainage was less intensive in the Late Prehistoric II period than before and that maize horticulture, if practiced at all, was limited. Yet sites in both of these parts of the Trinity drainage have produced items characteristic of Plains Indian sites, such as shell-tempered ceramics and diagnostic lithic tools.

\section{Historic Period}

By the eighteenth century, immigrant Plains Indian groups had moved into and beyond northcentral Texas, and their documentation by traders and explorers marks the start of the historic period. Documentary sources suggest that the Apache, Caddo, Comanche, Delaware, Kickapoo, Kitsai, Tonkawa, Wichita, and Yojaune traversed the region at various times during the period (Campbell 1983; Newcomb 1961; Newcomb and Campbell 1982). But archeological sites that can be associated definitely with historic groups are few. The Wichita are known to have moved into Texas from Oklahoma and Kansas in the early 1700 s. Sites attributable to the historic Witchita have been identified at the edges of north-central Texas. Among these are the Stansbury site in Hill County, now inundated by Lake Whitney (Stephenson 1970). Excavations at the site produced burials, house structures, storage pits, and a variety of aboriginal artifacts, along with European ceramics, glass beads, metal arrow points, and flintlock musket parts. A cluster of Wichita sites also occurs to the north along the Red River in Montague County. These sites are known collectively as Spanish Fort and occur on both the Oklahoma and Texas sides of the river. Woodall (1967b) excavated one of these sites, named the Upper Tucker site, which produced artifacts and features similar to those discovered at the Stansbury site. Wichita sites both on the Brazos and Red Rivers were situated atop high terraces that overlook the rivers.

\section{CENTRAL ROLLING PLAINS}

\section{Previous Research}

The central Rolling Plains region includes the 13 counties in TxDOT's Abilene District plus the two northernmost counties (Stephens and Eastland) in the Brownwood District. The Rolling Plains, also known as the Lower Plains, Redbed Plains, or Rolling Mesquite Plains, is one of the least-defined archeological regions in Texas (Brown et al. 1982; Wulfkuhle 1986). Thoroughly investigated sites are few within the study area, and many lack reliable dates. As a result, the prehistoric chronology for the central Rolling Plains relies almost entirely on diagnostic artifacts recovered during surveys and the cultural chronologies from surrounding regions. 
Although most of the central Rolling Plains study area is characterized by erosion-exposed redbeds (Triassic and Permian deposits), two prominent physiographic features are noteworthy. The two westernmost counties, Borden and Howard, extend up onto the High Plains and encompass portions of the Caprock Escarpment and the Llano Estacado flatlands underlain by the Ogallala Formation. The other feature is a series of extensive limestone plateaus-essentially erosional remnants of the greater Edwards Plateau - that run in a band just south of Interstate Highway 20 from west to east across Howard, Mitchell, Nolan, Taylor, Callahan, and Eastland Counties. These plateaus collectively are called the Callahan Divide, and they rise as much as $250 \mathrm{~m}$ above the surrounding landscape and constitute the drainage divide between the Brazos and Colorado Rivers. Thus, although most of the study area can be characterized as archeologically homogenous, the cultural remains associated with the Llano Estacado and Callahan Divide are distinctive from those of the Rolling Plains. Perhaps most significant, the Cretaceous limestones of the Callahan Divide constitute the northernmost exposures of Edwards Group formations in Texas and are rich in high-quality cherts (Frederick and Ringstaff 1994). Primary chert outcrops are encountered on and around the margins of the divide, and secondary gravel deposits (upland lag and stream channel gravels) are found for some distance all around the isolated Cretaceous plateaus.

Not only does the Callahan Divide represent the northermost Cretaceous limestone outcrops in Texas, but the divide also constitutes the northernmost occurrence of classic burned rock middens in the state. Creel's (1986:Figure 6) dissertation shows that burned rock middens are found in Jones, Taylor, and Callahan Counties, and subsequent researchers have located additional middens (e.g., Katz and Katz 2002). There are different theories as to how and why limestone rocks were used in cooking processes that resulted in the formation of middens, but there is little doubt that many of the archeological sites in the Callahan Divide area, especially the burned rock middens, were closely tied to central Texas during some cultural periods.

Some of the earliest archeological work in the state was done in and around Abilene by
Cyrus N. Ray, a trained osteopath and avocational archeologist who also was one of the founders of the Texas Archeological Society in 1928. His primary interest was in the antiquity of humans in North America. Specifically, Ray (1934:107) sought evidence for "...Pleistocene man in Texas, if any such existed." Ray, along with E. B. Sayles and Dr. Otto Watts, began conducting surveys along the Clear Fork of the Brazos River and Big Elm Creek (Wulfkuhle 1986), ultimately documenting sites scattered over 12 counties. Ray thought that many of the sites he investigated were ancient because cultural remains were deeply buried in alluvial terraces. He was correct in a few cases but was incorrect more often than not. Without the aid of radiocarbon dating to accurately date the deposits, neither Ray nor his contemporaries realized the complex and dynamic nature of the river systems in the Rolling Plains or understood the significance of paleoclimatic changes on the archeological record.

Beyond his early man studies, Ray defined several cultural groups from later times, but most of these designations have long since been discarded or modified. Wulfkuhle (1986:Figure 16) and Creel (1990:13-22) provide good summaries of the various cultural classification schemes that have been applied to the central Rolling Plains.

A few large area surveys have been completed within or close to the study area (see Boyd 1997:Table 6 and Figure 13). These include Boyd et al. (1989), Brown and Anthony (1992), Cliff et al. (1991), Etchieson et al. (1979), Jelks (1952), Lintz et al. (1991), Lynott (1979), Saunders et al. (1992), Shafer (1971), Staley and Evaskovich (1993), Thurmond et al. (1981), Tunnell (1960), and Wulfkuhle (1986). Moreintensive investigations, especially large-scale excavations, have been rather limited. In general, the archeological data for the central Rolling Plains are insufficient to support detailed temporal, spatial, and functional comparisons of sites for various prehistoric time periods. With some exceptions, much of the cultural chronology sequence for the central Rolling Plains must be extrapolated from other nearby areas, specifically the Panhandle-Plains region, central Texas, or north-central Texas. For this discussion, a blend of the cultural chronologies proposed for central Texas by Collins (1995:Table 2) and the Caprock Canyonlands 
by Boyd (1997:Figure 26) is used: Paleoindian (11,500 to 8800 B.P.); Early Archaic (8800 to 6000 B.P.); Middle Archaic (6000 to 4000 B.P.); Late Archaic (4000 to 1500 B.P., or 2000 B.C. to A.D. 500); Late Prehistoric I (A.D. 500 to 1100 or 1200); Late Prehistoric II (A.D. 1100 or 1200 to 1541); and Historic (A.D. 1541 to 1875).

\section{Paleoindian Period}

Paleoindian artifacts in the central Rolling Plains are generally surface finds in isolated contexts. Identified point types include Clovis, Folsom, Plainview, Scottsbluff, and Angostura (Meltzer 1986; Meltzer and Bever 1995; Prewitt 1995). The bulk of the information available for the Paleoindian period is based on documented surface collections and surveys conducted in the first half of the twentieth century, like those of Ray $(1929,1934,1938,1940)$. He correctly recognized some deeply buried sediments, which he named the "Durst soils," as being ancient deposits (Ray 1930:45-46; Ray and Bryan 1938; Sellards 1952:36; Suhm et al. 1954:99).

Based on the scarcity of sites and the presence of nonlocal materials, some researchers have concluded that Paleoindian groups were highly mobile with low-density populations (Hoffman 1989:25). The environment during the Paleoindian period was most likely much wetter and cooler than today (Collins 1995; Holliday 1997; Wendorf and Hester 1975). In terms of subsistence strategies, researchers have long thought that Paleoindians relied primarily on big-game hunting, a rather specialized lifestyle evidenced by killing and butchering tools found in association with extinct forms of bison (Hoffman 1989:25). Although kill sites are common for this period, small seasonal campsites and secondary processing sites also are known (Harrison and Killen 1978:87; Johnson 1977) but are more difficult to identify. Recent finds are challenging the strict notion of nomadic biggame hunters and suggest Paleoindians had a broader hunting-gathering strategy (Collins 1995:381-383; Collins et al. 1989).

Several Paleoindian sites are reported in the study area, but even the most significant sites are known only through excavations more than 30 years ago. The Lone Wolf site near Colorado City (Mitchell County) is not a particularly famous site, but the 1925 finding of distinctive lanceolate projectile points (now typed as Milnesand and Plainview or Firstview) in association with extinct bison at this locality predated the nowfamous investigations at the Folsom site that began in 1926 (Holliday 1997:161, 166; Wormington 1957:110).

The Office of the State Archeologist conducted excavations at the Adair-Steadman site (41FS2) in Fisher county in the 1970s. It is a Folsom campsite situated on a high terrace above the Clear Fork of the Brazos. The work has yet to be reported, but Tunnell (1975) examined the stone artifacts and reported on the lithic technology associated with Folsom point production using local Edwards cherts.

Mallouf (1989) reported on investigations at the Yellow Hawk site, a Clovis lithic workshop on the Callahan Divide. This Taylor County site contains rare evidence of a discrete Clovis point production episode at an upland chert locality in a nondepositional setting. The time of this event could not be established through independent dating.

Other significant Paleoindian sites in the study area that have been investigated, albeit minimally, include the McLean site (Wulfkuhle 1986:66) in Taylor County, Gibson site (Ray 1940) in Shackelford County, and the Biedleman Ranch site in Stonewall County (Wulfkuhle 1986:69).

\section{Archaic Period}

As originally defined, the Archaic period spans many thousands of years, from 8800 to 1500 B.P. Compared with the preceding Paleoindian period, Archaic life was significantly different, reflecting a long period of relative cultural stability (Collins 1995:383). Subsistence patterns appear to have been more diverse, with evidence for greater exploitation of local environments (Hofman et al. 1989:45). There is evidence for an increase in the dietary importance of smaller game animals, fish, and wild plant foods (Cliff et al. 1991:15). A hunting and gathering lifestyle prevailed, with seasonal travelling to use different food resources in various localities but a marked decrease in group mobility (Hofman et al. 1989:58; Weir 1976).

The Rolling Plains Archaic often has been divided into Early, Middle, and Late subperiods (e.g., Etchieson et al. 1979; Kelley 1947a; Prewitt 1981, 1985; Story 1985a; Suhm et al. 1954; Weir 1976). Distinctions between these periods are 
based in large part on changes in projectile point styles, but the transitions between periods may well coincide with climatic shifts (Boyd 1997:226-231; Collins 1995:Tables 1 and 2). Collins (1995:383) notes for central Texas that there were distinctive cultural changes within the broad Archaic tradition, but that the nature and timing of those shifts are poorly understood. It is clear, however, that the appearance and proliferation of burned rock middens in Archaic times (Collins 1995:384) is one of the most significant prehistoric cultural events in this part of Texas.

The Early Archaic period (8800 to 6000 B.P.) is not well represented in the Rolling Plains, and most of the finds come from mixed contexts. Some archeologists have suggested a transitional stage between the Paleoindian and Archaic cultures that exhibits similarities to both periods (Hoffman et al. 1989; McKinney 1981; Sollberger and Hester 1972). The transition from late Paleoindian to Early Archaic was a time of considerable environmental change, with a cooler, wetter climate giving way to much warmer, drier conditions (Collins 1995). In fact, most paleoenvironmental evidence suggests that a major period of aridity, originally called the Altithermal period by Antevs (1955), occurred over central Texas in early to middle Holocene times from about 8000 to 4000 B.P. (Collins 1995:Table 2, 378-380). In the central Rolling Plains, the Early Archaic is seen as a period of increasing aridity that led to fullblown drought conditions during the Middle Archaic. Over much of Texas, these climatic conditions had profound effects on human populations and on the cultural remains that survive, or failed to survive, in the archeological record.

In the study area, representative Early Archaic dart points include stemmed, cornernotched with expanding stems, triangular, and heavily barbed forms, including Angostura, Gower, Martindale, Uvalde, and Wells (Collins 1995:Table 2; Turner and Hester 1999). In addition, Clear Fork gouges, burins, circular scrapers, a variety of bifaces, and grinding implements are also present. Only a small number of sites dating to the Early Archaic have been reported for the central Rolling Plains Region, and no major excavations associated with this period have been reported. The relative paucity of sites from this time period appears to be a result of a severe erosional episode (or episodes) in the Southern Plains during Middle Archaic times. Widespread erosional scouring is thought to have removed significant amounts of early Holocene deposits and Early Archaic archeological remains (Boyd 1997:226-231). Given the limited information available for this time period, it is difficult to elucidate human adaptive strategies and lifeways. But data from central Texas suggests diffuse economic systems with people exploiting an array of resources and alternating between various subsistence activities (Story 1985a:39). It is safe to say that the overall hunter and gatherer population density was low during this period.

The Middle Archaic, from 6000 to 4000 B.P., is poorly represented in the study area but may include Ray's (1945) Clear Fork complex originally assigned to the Paleoindian-Archaic transition (Cliff et al. 1991:15). In the central Texas archeological record, there appears to have been a population increase during the Middle Archaic and development of regionally distinct cultural patterns along with changes in settlement patterns, economic and social systems, and technology (Collins 1995:384). If these changes occurred in the Rolling Plains, evidence is extremely limited because of geomorphic reasons. A considerable body of paleoclimatic evidence suggests that extremely xeric conditions (i.e., the latter half of the Altithermal) and erosional scouring were prevalent in the Southern Plains from ca. 6500 to 4600 B.P. (Boyd 1997:226-228; Hughes 1991:19-20). With a combination of low human population density because of droughts and concurrent erosional scouring, it is not surprising that Middle Archaic archeological sites are rare.

Although human populations may have been increasing in central Texas during the Middle Archaic, there appears to have been minimal human activity on the Llano Estacado and Rolling Plains (Boyd 1997:52; Hughes 1991:20). In the central Rolling Plains, Middle Archaic sites are usually represented by surface scatters, and no substantive investigations of buried components have been made. Collins (1995:Table 2) lists Andice, Bell, Taylor, Nolan, and Travis points as definitive Middle Archaic points in central Texas, but these types are rare in the central Rolling Plains. Prewitt (1995) shows only a few Nolan points occurring within the study area.

In central Texas, burned rock middens be- 
came common during the Middle and Late Archaic periods (Black et al. 1997:273-280; Collins 1995:384). The ages of many of the burned rock middens known in Callahan, Jones, Mitchell, Shackelford, and Taylor Counties are unknown (Creel 1986; Mauldin and Nickels 2003), but some of them may well be Middle to Late Archaic in age.

The Late Archaic saw the development of an array of new cultural patterns and a proliferation of projectile point styles (Collins 1995:Table 1; Story 1985a:45). Subsistence patterns in the central Rolling Plains changed as people became more reliant on bison hunting, with herds becoming more common after long periods of bison absence or scarcity during part of the Early Archaic and all of the Middle Archaic (Dillehay 1974). The Late Archaic period in the study area is most commonly represented by open campsites and isolated burials, but bison kill and processing sites are common farther north in the Rolling Plains (Boyd 1997:Table 59, Figure 78).

Sites in the study area contain a variety of Late Archaic dart point styles-Castroville, Darl, Edgewood, Elam, Ensor, Fairland, Frio, Marcos, Marshall, Nolan - that are often associated with central Texas (Boyd 1997:Table 60; Collins 1995:Figure 1), along with some styles common in north-central Texas such as Eliasville, Ellis, and Godley (Cliff et al. 1991:16). Late Archaic components investigated at Lake Alan Henry in Kent and Garza Counties produced Castroville, Marcos, and Marshall dart points (Boyd 1997:249-250). Mack (1994) reports on an intensive surface collection of the Van York site (41BD8) in Borden County that yielded Edgewood and Ellis points. In the 1980s, the Texas Department of Highways and Public Transportation conducted a limited testing project at 41KT32 on the floodplain of the Brazos River in Kent County. Small expanding-stem dart points indicated Late Archaic occupations (Denton 1983).

Late Archaic burials from Kent (Holden 1929) and Mitchell (Ray 1936) Counties contain unusual lunate stones made of exotic rocks as grave offerings. The Mitchell County find was a cremated burial that had Fairland, Marcos, and Shumla points associated with it. The cultural significance of lunate stones and cremation as mortuary traits are not fully understood (Boyd 1997:253-257).

\section{Late Prehistoric Period}

The Late Prehistoric period (1200-450 B.P.) was a time of rapid and significant changes among prehistoric cultures. Technological changes, including the emergence of the bow and arrow, the use of ceramics, and the adoption of horticulture, occurred at different times in different locations. For whatever reasons, people in some regions adopted the bow and arrow later than others, and some people never adopted agriculture, but others did. In the study area, some Late Prehistoric sites and assemblages continue to show similarities to central Texas, but there were distinctive cultural influences in the Rolling Plains that are not evident in central Texas. Across much of central Texas, there is evidence of increasing relationships with Caddoan peoples to the east, but the Rolling Plains region has stronger evidence of influences from Plains Woodland and Plains Village peoples to the north and Puebloan peoples to the west, as well as limited Caddoan influence (Boyd 1997:491-496; Cliff et al. 1991:16).

In Late Prehistoric I times, which lasted from about A.D. 500 to 1100 or 1200 , two cultural complexes are recognized in the study area. There were probably more than two groups within the central Rolling Plains at this time, but only the Palo Duro and Blow Out Mountain complexes are recognized as definable archeological entities.

The core area of the Palo Duro complex is situated along the Caprock Escarpment and mainly to the north of the study area (Boyd 1997:Figure 84), but the southern end of the culture area extends into the Rolling Plains. At least two sites in the study area-the Big Spring site in Howard County and the South Sage Creek site in Kent County-are attributed to the Palo Duro complex (Boyd 1997:Figure 85 and Table 66 ). One of the most significant sites of the Palo Duro complex is the Sam Wahl site (41GR292) in Garza County, immediately west of the study area. The discovery of a circular pithouse, large subterranean storage pits, and baking pits there led to a comparative study and redefinition of the Palo Duro complex (Boyd 1995, 1997). The complex is considered to represent foraging peoples who primarily occupied the canyonlands along the Caprock Escarpment but also ventured onto the High Plains and Rolling Plains, probably seasonally. Deadman's arrow points are the 
distinctive style for the complex, but Scallorn and stemmed Alba or Alba-like arrow points also are found. These people do not appear to have made any pottery, but they imported plain brownware pots from the Jornada Mogollon region to the west. Bison were of little importance, presumably because they were so scarce from around A.D. 500 to 1000 , but hunting deer and smaller animals was important. Paleoclimatic evidence suggests cooler and wetter conditions during this time, and Palo Duro peoples harvested a range of wild plant foods, including mesquite beans and shin oak acorns. They used a variety of grinding tools and baking pits to process these and other plants. Although no cultigen remains have been found at any Palo Duro complex sites, the possibility that the people practiced limited horticulture cannot be ruled out.

The recent finding of corn at the Bear Branch site (41CA13) in Callahan County sheds new light on agriculture in the Callahan Divide area. A charred corn kernal (Zea mays) was recovered from a cooking pit associated with a burned rock midden (Katz and Katz 2002), and a bulk sediment radiocarbon date of A.D. 1160 to 1290 (calibrated, two-sigma) is associated. To the authors' knowledge, this is the only documented occurrence of prehistoric corn in the Rolling Plains region and the westernmost reported occurrence in northern Texas, excluding the Panhandle (see Henrietta complex below). The cultural affiliation of this site is not certain. Katz and Katz (2002) suggest the Bear Branch site belongs to the Blow Out Mountain complex (see below), but the cultural affiliation is complicated by a fairly long span of occupation (estimated to be from A.D. 600 to 1600) and a variety of diagnostic points. Along with a few dart points, the Bear Branch assemblage includes early-style arrow points such as Scallorn and Alba and latestyle arrow points such as Fresno, Perdiz, and Washita. The site definitely has multiple use episodes, and it could represent occupations by different groups over time or perhaps contemporaneous use by multiple groups. Some of the occupations could be associated with the Henrietta or Palo Duro complexes. The Scallorn and Alba points in particular suggest an affiliation with the late Palo Duro complex, despite the absence of imported Mogollon brownware pottery. Regardless of who the occupants were around A.D. 1200, the corn likely indicates that people were farming at or close to the Bear Branch site during the transition time from Late Prehistoric I to II.

Creel (1990:15-18) defined the Blow Out Mountain complex based on his work at the East Levee site, and this culture area encompasses much of the central Rolling Plains (see Boyd 1997:280-281). The complex is transitional between Late Prehistoric I and II and presumably dates from about A.D. 800 to 1300 . As it is currently defined, the Blow Out Mountain complex subsumes Cyrus Ray's (1929) Sand Dune Culture and Sayles and Ray's Brazos River Culture (Sayles 1935; see Ray and Sayles 1941). Blow Out Mountain also includes many cairn burial sites and "rock-covered mounds" excavated in the study area during the 1930s and 1940s. Evidence in many of these graves suggests that intercultural violence was prevalent in the Rolling Plains during Late Prehistoric times (see Boyd 1997:280-281, 491-496; Brooks 1994).

The Blow Out Mountain strata at the East Levee site, in contrast to the Late Archaic strata below and the Toyah phase strata above, contained no bison remains. The stone-lined hearths, faunal remains, and stone tool assemblage all indicate generalized hunter-gatherers. No ceramics are associated with the complex. Typical arrow points fall into one of four categories: stemmed points often typed as Alba or Bonham; Chadbourne points (Turner and Hester 1999:207) that appear to be smaller versions of Darl or Zephyr dart points; contracting-stem Cliffton-like points; and side-notched Washita points. Of particular note, many of the Alba-like points are longer and have serrated blades, and this form is most commonly associated with human burials. These were named Moran points by Forrester (1987), and many specimens found in burials appear to be arrow tips that caused death (Boyd 1997:280-281).

There are some interpretive problems with the Blow Out Mountain complex because of the limited sample of excavated components and the lack of chronological control. It may be that Blow Out Mountain represents a single culture undergoing rapid changes during a critical time from A.D. 800 to 1300 . Or, it may be that the complex needs to be split into two or more cultural groups as more data come to light.

The transition from the Late Prehistoric I to Late Prehistoric II periods, occurring sometime around A.D. 1100 to 1200 , was a time of sig- 
nificant cultural changes across the American Southwest and Southern Plains. In the Southern Plains, it is generally linked with a shift from cooler, wetter conditions to a warmer, drier climate. These drier conditions are presumed to have been more favorable for grasslands and bison. It is at about this time that bison populations seem to have exploded in the Southern Plains, and most cultures shifted subsistence strategies to intensify bison hunting pursuits (Dillehay 1974). Many cultures also intensified their agricultural pursuits at this time, apparently shifting from simple horticultural practices to more substantial farming primarily involving corn (Brooks 1989; Hoffman et al. 1989). The extent to which this Plains Woodland to Plains Village transition occurred, or did not occur, in the central Rolling Plains is uncertain because of the lack of substantive archeological excavations.

During the Late Prehistoric II period, local cultures may have modified their subsistence base to incorporate or intensify bison hunting while other groups moved into the Southern Plains from surrounding areas to exploit the expanded bison range. But some climatic fluctuations within the Late Prehistoric II period may have been significant, and there is evidence of two major drought periods: one around A.D. 1275 to 1300 and another around A.D. 1550 to 1600 (Woodhouse and Overpeck 1998). These periods certainly would have affected animal and human populations and may have served as catalysts for cultural changes.

At least three different cultural groups are thought to have inhabited part or all of the study area during the Late Prehistoric II period and into Historic times. These groups were associated with the Garza complex, Henrietta complex, and Toyah phase. All three cultures seem to be present in the study area (see Boyd 1997:Figure 96), and the central Rolling Plains is within a "shared area" identified by Johnson (1994:Figure 105) as a place where several cultural groups lived and interacted. Because of the dynamic cultural nature of this shared area during Late Prehistoric II times, the archeological remains are diverse, intriguing, and confusing.

The Garza complex (Boyd 1997:495) is represented by bison kill and processing sites, shortterm hunting camps, rockshelters, and residential base camps with evidence of tipi-like dwellings. Isolated burials also are associated.
Material culture includes a triad of bison hunting and skinning tools-the distinctive Garza and Lott points, Plains-style end scrapers, and beveled knives. Stone tool assemblages are strictly functional at most Garza sites, particularly those related to bison hunting and processing, and striated pottery sherds from plainware pots are often associated. In contrast, at residential bases where more-intensive occupations occurred, a range of imported Puebloan items is usually found. Obsidian, turquoise, and Olivella shell beads are sometimes present, and decorated Puebloan pottery is abundant at some sites. Further evidence of Puebloan trade is found at seventeenth-century sites in the form of historic-age materials (e.g., majolica pottery, gunflints and lead, cow and horse bones) that were obtained from Spanish colonial settlement or mission pueblos like Pecos.

The Garza complex extends into the northwestern counties of the study area, and the Longhorn and Headstream sites in Kent County (41KT53 and 41KT51) are two Garza complex sites that have been intensively investigated (Boyd 1997:380-381). Garza peoples were major players in the Southern PlainsPueblo interaction during the middle to late 1600 s and appear to have processed large numbers of bison hides for the Pueblo trade. The intensity of Plains-Puebloan trading increased through time, and it is notable that prehistoric Garza sites (i.e., those before A.D. 1541) may look very different from protohistoric Garza sites dating after about 1650 .

Krieger (1946) defined the Henrietta complex based primarily on late 1930s excavations at the Harrell site (Hughes 1942) to the east of the study area in Young County. Most of the sites attributed to this complex are east of the central Rolling Plains study area (see the culture history section for North-Central Texas), but the westernmost extent of this culture area appears to include Callahan, Eastland, Shackelford, and Stephens Counties. The Henrietta complex represents the southernmost Plains Village manifestation in Texas (Boyd 1997:360-361; Brooks 1989:85-86). It is characterized by small circular to oval houses (with walls lined with posts and having three or four interior posts), storage pits, a variety of arrow points (Fresno, Harrell, Scallorn, and Washita being most common; Alba, Bonham, Eddy, and Perdiz being less common), and Nocona Plain pottery tempered with 
limestone or shell. Henrietta peoples did some farming. Charred corn has been recovered from sites in Young and Cooke Counties, and bison scapula hoes were used as gardening tools. Henrietta peoples were tied into interregional exchange networks, with trade to the west and northwest as indicated by obsidian, Alibates flint, and Puebloan pottery, and trade to the east as indicated by celts and Caddoan pottery.

The Henrietta complex is somewhat confusing because of the low number of investigated sites and the lack of chronological control. It shows similarities to the Blow Out Mountain complex to the west and to the Sanders and Wylie phases to the east (Boyd 1997:361; Brooks $1989: 85-86)$. One thing that is clear, however, is that there is a high frequency of violence in burials, and warfare seems to have been prevalent in this culture (Boyd 1997:360-361).

The Toyah phase was first proposed by Kelley (1947b) and later revised by Jelks (1962). More recently, Toyah culture was redefined by Johnson (1994) based on his work at the Buckhollow site in Kimbell County. He defined what he called a Classic Toyah culture area that extends northward up into the Rolling Plains region and to the southern edge of the study area. He also defines a shared culture area that encompasses the study area (Johnson 1994:Figure 105). Classic Toyah culture is identified by Perdiz arrow points, Plains-style end scrapers, beveled knives, and bone-tempered plainware pottery (often called Leon Plain).

Toyah phase artifacts are found outside the Classic Toyah area, particularly to the north and northwest, but they seem to be mixed with traits and materials from other cultures. Evidence that Toyah people ventured into the Rolling Plains includes Perdiz-associated bison-processing sites to the south of the study area (e.g., the Elm Creek site in Concho County and the Rush site in Tom Green County), but Perdiz arrow points are found as far north as the southern Llano Estacado (Boyd 1997:82). One particularly interesting find in the study area is the WeaverRamage cache in Kent County (Tunnell 1978), containing more than 800 items of high-quality Edwards chert, including a Perdiz point. It is thought to be a cache made by Toyah people. Within the shared area of the Rolling Plains,
Perdiz points are found alongside other distinctive arrow point styles (such as Cliffton, Garza, Harrell, Lott, and Washita) and with a wide range of ceramic types. As noted with the Henrietta complex above, violence in Toyah phase burials indicates that the groups in the shared area were not always friendly toward each other (Boyd 1997:364; Prewitt 1981:83).

\section{Historic Period}

The Historic period begins with Coronado's entrada in A.D. 1541 and ends in 1875. The central Rolling Plains study area was undoubtedly occupied at various times by Apaches, Jumanos, Comanches, and other Native American groups, but recognizing the archeological remains of these historic cultures is difficult at best.

When Coronado entered the northern part of Texas in 1541, he met two different groupsQuerechos and Teyas-and they were enemies (Boyd 2001). Most researchers agree that the Querechos were Apache peoples, and an Apache presence in the Southern Plains seems certain in the latter 1500 s and 1600 s. There is less certainty as to the identity of the Teyas, but the most prominent theory is that they represent Jumano peoples described in Spanish accounts from the seventeenth and eighteenth centuries (Boyd 2001; Kenmotsu 2001). The Jumano culture area probably extended up into the Rolling Plains, but its precise boundaries are not well documented (Hickerson 1994:Map 6; Kenmostsu 2001:Figure 1). No sites in the study area are attributed to the historic Apache or Jumano.

The cultural dynamics in the Southern Plains changed radically once again between 1700 and 1725 when the Comanches suddenly appeared (Wallace and Hoebel 1986:6-8). To combat the Comanche threat, it appears that the Jumano and Apache may have become allies in the early 1700s (Kenmotsu 2001:33), but these and other groups were ultimately displaced by the more-powerful Comanche bands. They remained the dominant force in the Southern Plains until the 1870s, when the U.S. Army launched several campaigns and finally removed the Comanches and their allies from the region (Newcomb 1961:155-157). 


\section{SUMMARY OF IMPACT EVALUATIONS AND SURVEYS}

\section{3}

Seventy-seven projects distributed across the Abilene, Fort Worth, and Waco Districts were completed (Figure 4). Though included in the contract area, no work authorizations for projects in the Brownwood District were issued. These consisted of 25 Impact Evaluations and 52 Surveys. Combined, these work authorizations entailed efforts at 52 bridge replacements, 14 road realignment or widening projects (many also involving bridge replacements), 1 new road construction project, 1 hike-and-bike trail construction project, 5 projects involving upgrading or replacing existing culverts, 1 project involving construction of drainage improvements, 2 unspecified road maintenance or improvement projects, and 1 project involving replacement of an interstate highway interchange. During completion of these work authorizations, 10 newly discovered or previously recorded archeological sites were investigated. This section begins with an outline of the methods used in accomplishing the work authorizations. Next, the work efforts are summarized in terms of distribution and setting, followed by a discussion of the existing disturbances observed as they relate to the potential for archeological remains in good context at these locations and descriptions of the sites investigated. The section closes with a discussion of the utility of the fieldwork done under these work authorizations.

\section{METHODS}

Each work authorization done under this contract began with acquisition of the appropriate USGS map(s), a file search at the Texas Archeological Research Laboratory or the online Texas Archeological Sites Atlas for known sites in and near the project area, review of geologic and soils maps, and review of project plans to identify impact areas. The field methods employed varied depending on the type of project.

For Impact Evaluations, fieldwork typically consisted of on-the-ground examination of existing and proposed right of way on both sides of the road along the full length of the project area. Where right of entry had not been obtained for known or potential impact areas beyond the existing right of way, these areas were inspected visually across fence lines. The ground surface and any disturbed areas (e.g., road cuts, the backdirt of recently placed fiber optic or telephone lines, plowed fields, and so on) within and adjoining the existing right of way were examined for evidence of archeological remains. The primary thrust, however, was to record the kinds and extent of disturbance and determine the likelihood of archeological remains in undisturbed contexts. In most cases, this entailed examining visible stream cut banks and overall landscape geometry to form an opinion about the thickness and extent of Holocene alluvium that could host buried archeological deposits. Typically, shovel tests were not dug because cutbanks provided adequate information on sediment thickness.

For each bridge replacement or other Transportation Activity, a standardized Impact Evaluation form was completed recording anticipated impacts; location and extent of disturbances (e.g., ditches, fill sections, underground utilities, gullying and erosion, and other); location and extent of undisturbed right of way; surface visibility; subsurface exposures; geologic-geomorphic setting; nature, thickness, and origin of sediments; archeological remains observed; recommendations; land use; vegetation; personnel; and time spent. Each project area also was 


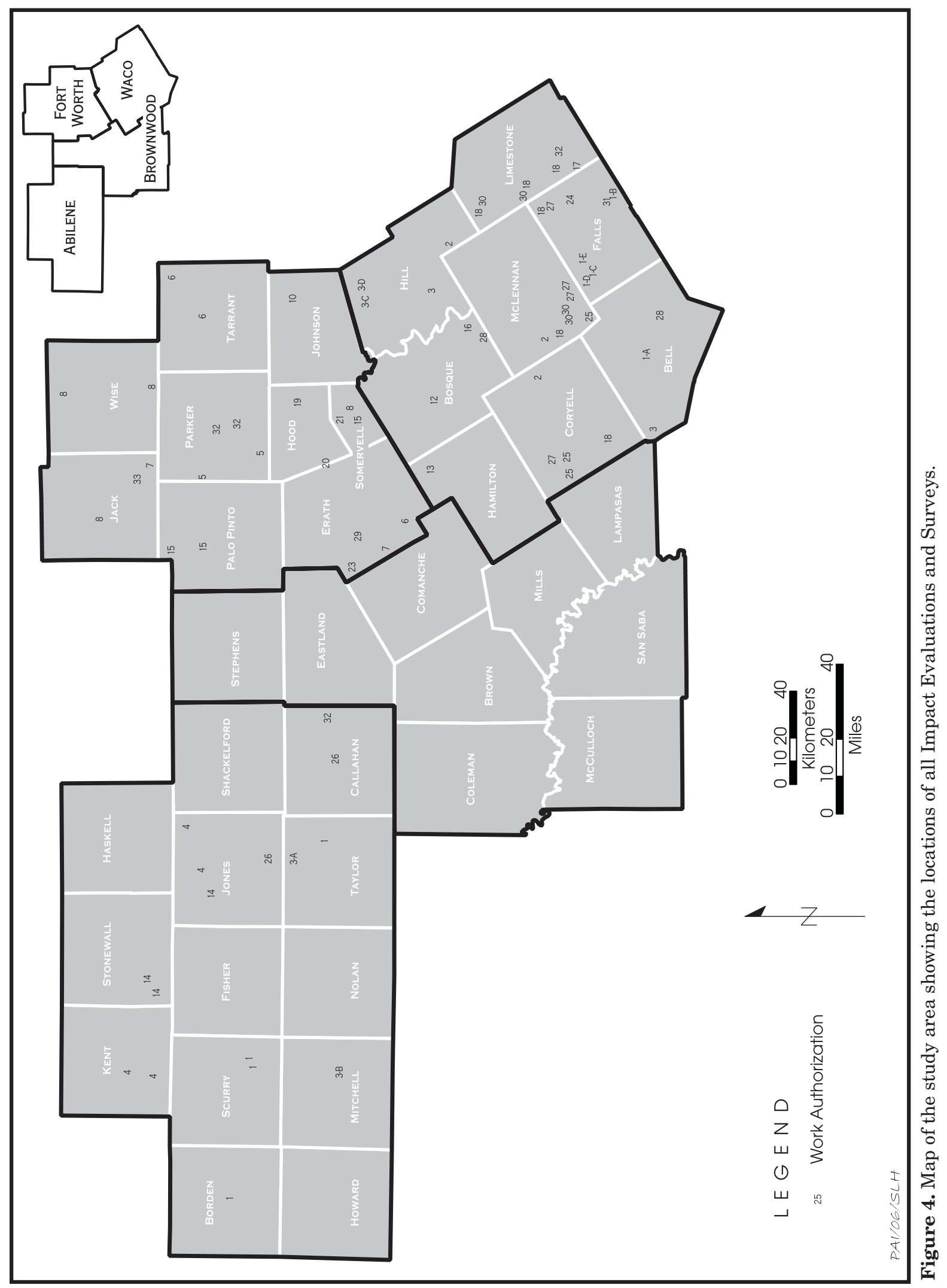


documented with color photographs. One or two people did Impact Evaluations, with the typical bridge replacement requiring 1-2 hours. Each of the Impact Evaluations that involved long stretches of highway was carried out as a series of on-the-ground inspections (i.e., at each stream crossing) following the methods outlined above, with the intervening upland areas generally subjected to windshield inspection.

For Surveys, fieldwork included excavating enough backhoe or Gradall trenches, or shovel tests, to constitute a good-faith effort toward determining whether archeological sites are present. As listed in Table 1, 295 trenches were excavated in 48 of the 52 survey areas, ranging from as few as 1 trench to as many as 24 . On 5 surveys, 23 shovel tests were dug in addition to trenches (range $=2-9$ tests). On 4 other surveys, only shovel tests $(\mathrm{n}=29)$ were dug because there are no deep Holocene deposits requiring trenching or because dense vegetation prevented backhoe access. On 2 surveys, 18 test pits $(1 \mathrm{x} 1 \mathrm{~m})$ were dug in addition to trenches. Twenty-seven of the surveys were restricted to existing rights of way; substantial parts of these survey areas (often half or more) were disturbed by existing roads and bridges. These 27 surveys involved excavating 143 trenches, 11 shovel tests, and 18 test pits. Twenty-five surveys were in relatively undisturbed proposed new rights of way or construction or drainage easements varying from 0.1 to 100 acres in size (median $=0.6-0.8$ acres). In surveying these areas, 152 trenches and 41 shovel tests were excavated. Trenches and shovel tests usually were placed according to the size and shape of each survey area, distributions of landforms, accessibility, and the locations of known sites rather than at specific intervals.

The trenches were at least $5 \mathrm{~m}$ long and $0.75 \mathrm{~m}$ wide and were usually at least $1.5 \mathrm{~m}$ deep (i.e., the anticipated maximum depth of substantial disturbance). After excavation, their walls were cleaned and examined for cultural materials. Stratigraphic descriptions were prepared for selected trenches to characterize the sediments. Shovel tests averaged $30 \mathrm{~cm}$ in diameter and were dug to varying depths depending on depth to bedrock, clay content, and water content. Test pits were $1 \mathrm{x} 1 \mathrm{~m}$ and were dug in $10-\mathrm{cm}$ levels to an average depth of $0.48 \mathrm{~m}$. The sediments removed from shovel tests and test pits were screened through 1/4-inch-mesh hardware cloth. A standardized Survey Summary Form was com- pleted describing the areas subjected to surface survey; noting visibility; indicating the number, depth, and placement of shovel tests, test pits, and trenches; listing the cultural materials observed and sites recorded; providing assessments and recommendations; and noting the personnel and time needed for the survey. Other documentation consisted of color photographs, Temporary Site Forms (for eventual submittal to the Texas Archeological Research Laboratory in TexSite format), stratigraphic profile descriptions, and project plans showing the locations of all excavations and sites. Surveys usually were done by two-person crews. The time required to complete the surveys varied depending on their size, the number of trenches and shovel tests or test pits excavated, and what was found. The range was 1.5-272 person-hours, with the median being 10 person-hours (excludes time spent by TxDOT personnel, including backhoe and Gradall operators).

\section{SYNOPSIS OF WORK AUTHORIZATIONS}

As listed in Table 1, 16 of the 77 projects involving fieldwork were in the Abilene District (Borden, Callahan, Jones, Kent, Mitchell, Scurry, Stonewall, and Taylor Counties), 23 were in the Fort Worth District (Erath, Hood, Jack, Johnson, Palo Pinto, Parker, Somervell, Tarrant, and Wise Counties), and 38 were in the Waco District (Bell, Bosque, Coryell, Falls, Hamilton, Hill, Limestone, and McLennan Counties). No fieldwork was conducted in the Brownwood District.

The projects in the Abilene District consisted of 6 Impact Evaluations and 10 Surveys for replacing 12 bridges, upgrading or replacing 2 existing culverts, reconfiguring 1 highway intersection, and constructing new drainage improvements in 1 project area. In the Fort Worth District, the work authorizations were for 6 Impact Evaluations and 17 Surveys on 14 bridge replacements, 6 road realignment or widening projects, 1 project involving new road construction, 1 culvert replacement, and 1 project involving unspecified road improvements. The projects in the Waco District consisted of $13 \mathrm{Im}$ pact Evaluations and 25 Surveys for 26 bridge replacements, upgrading of 2 culverts, 8 road realignments or widening efforts, 1 project involving unspecified road maintenance activities, and 1 hike-and-bike trail project. 


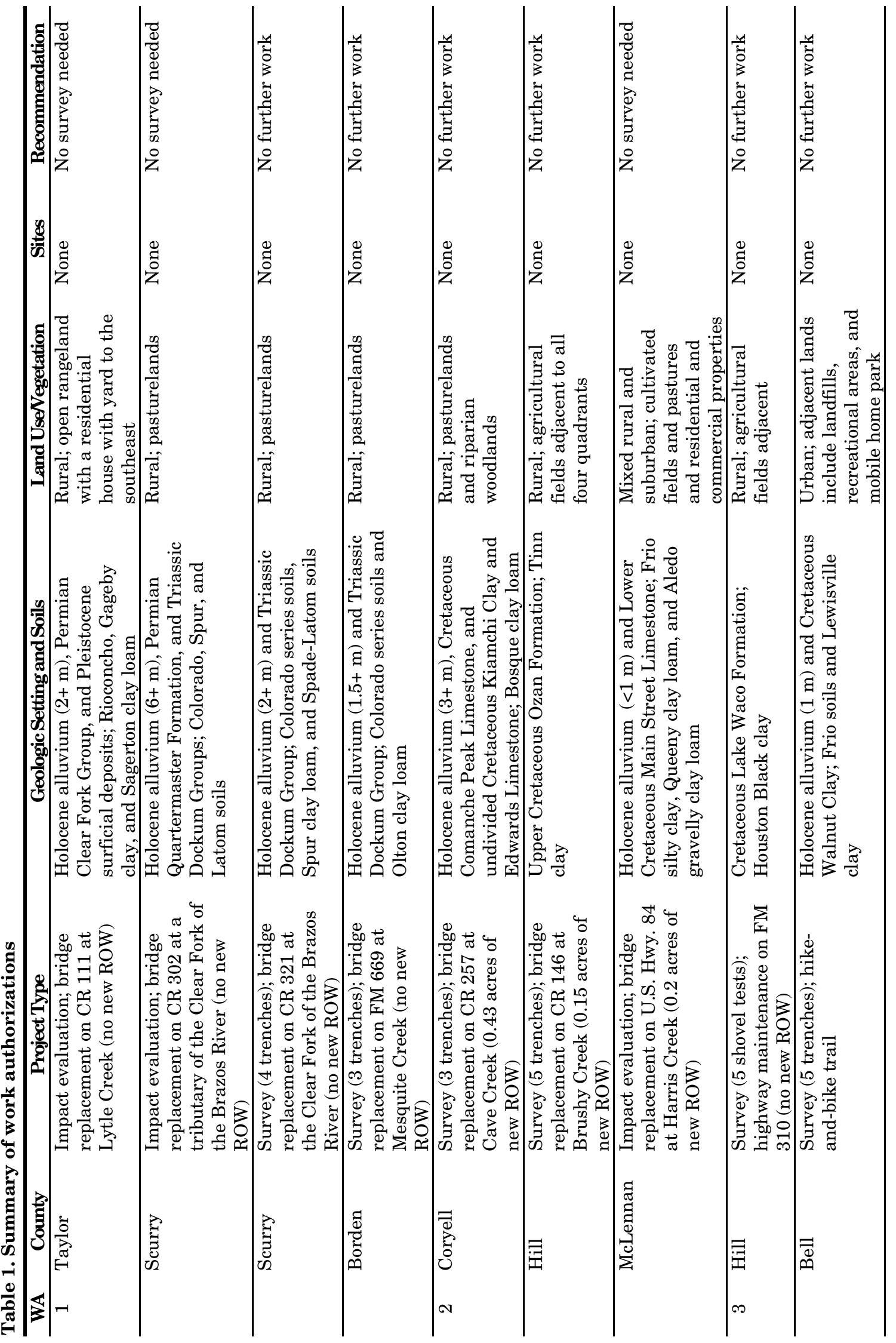




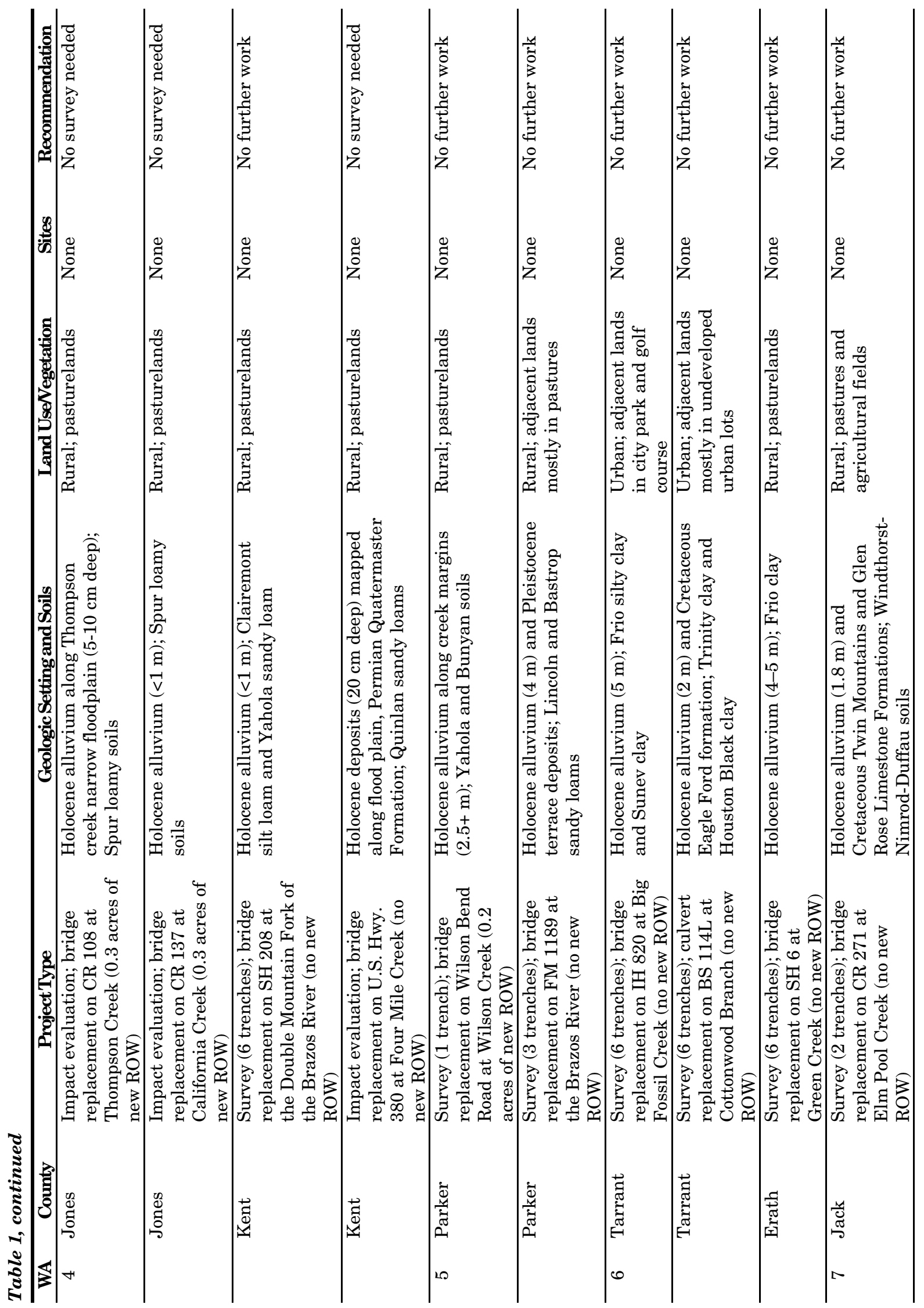




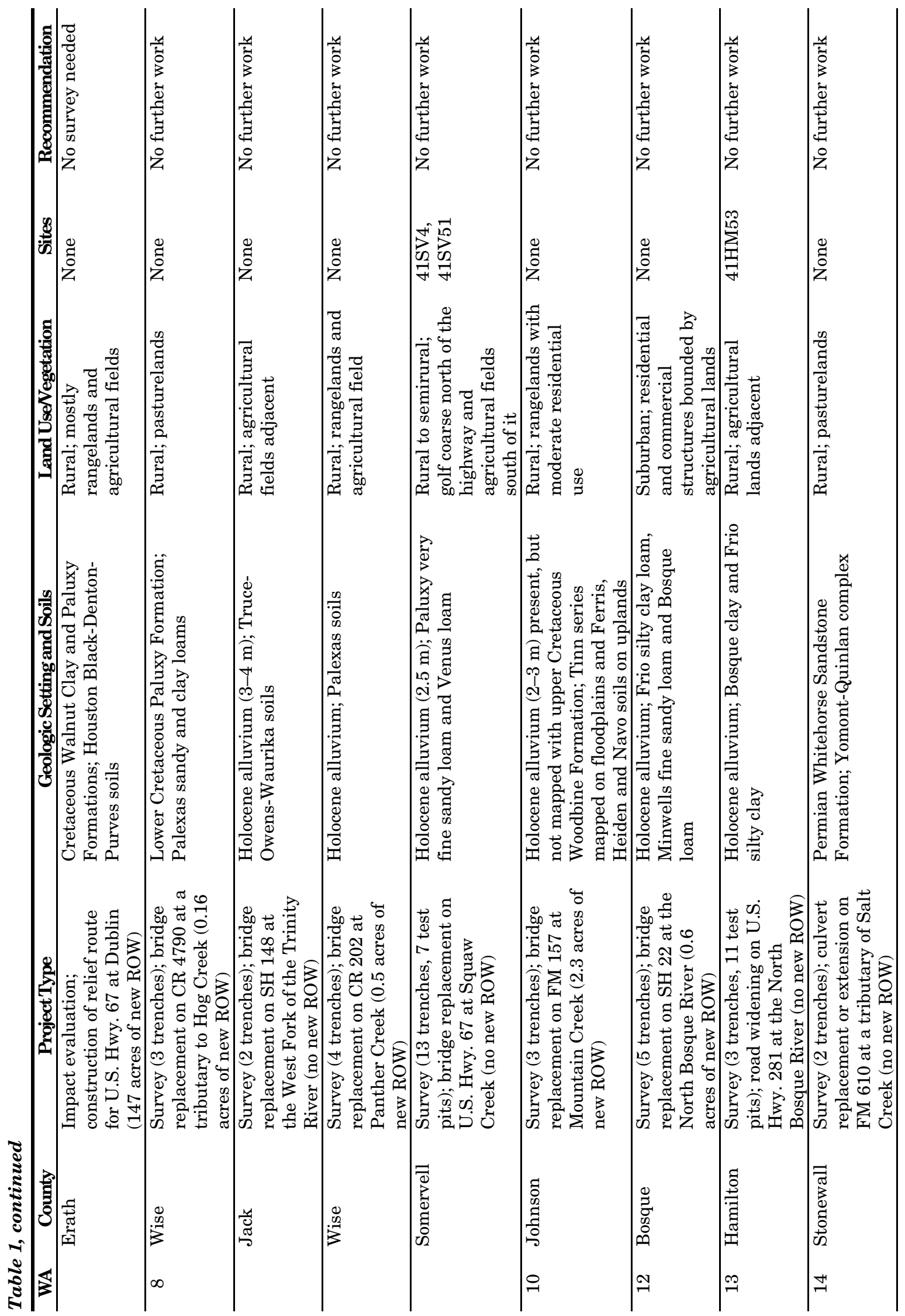




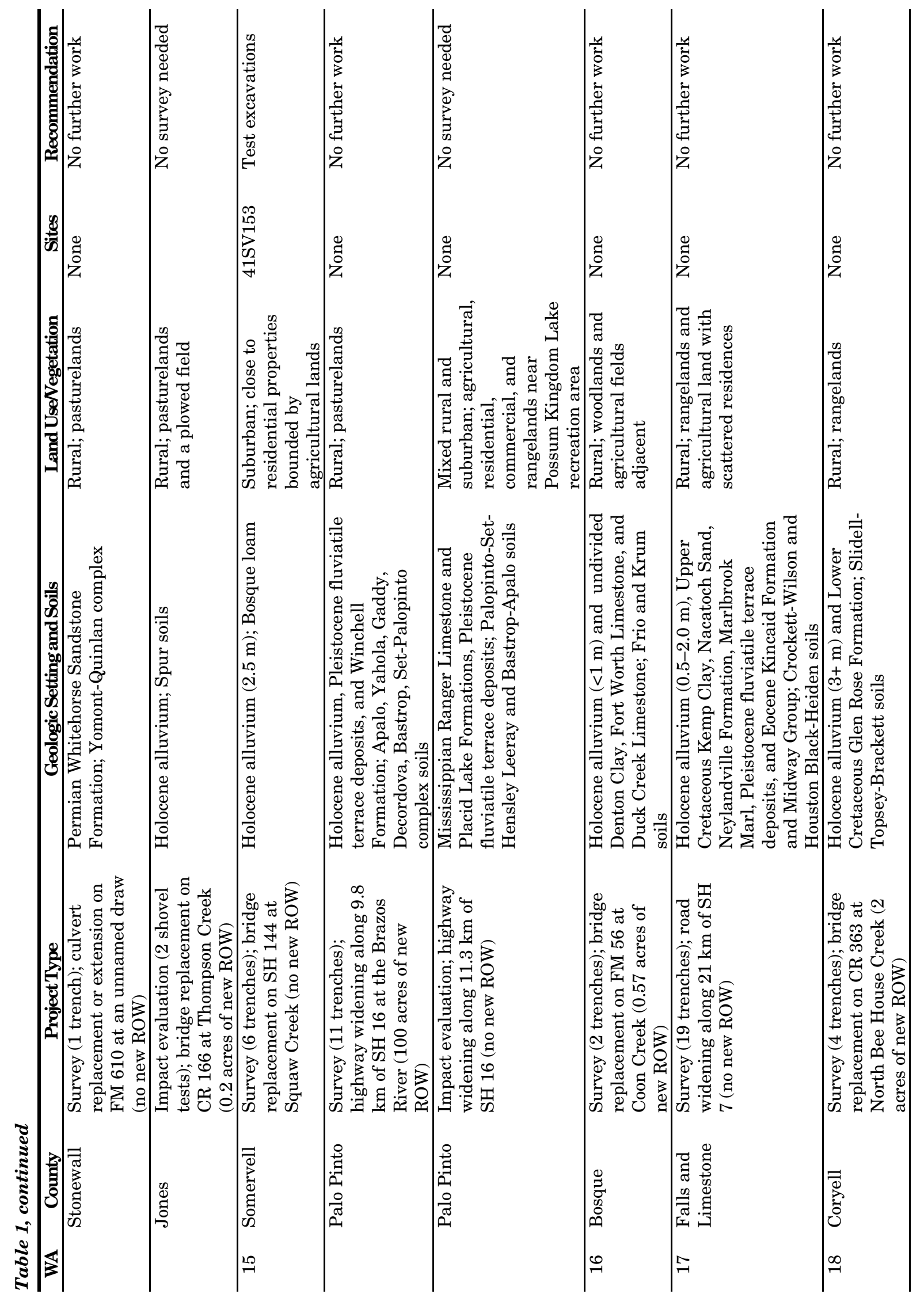




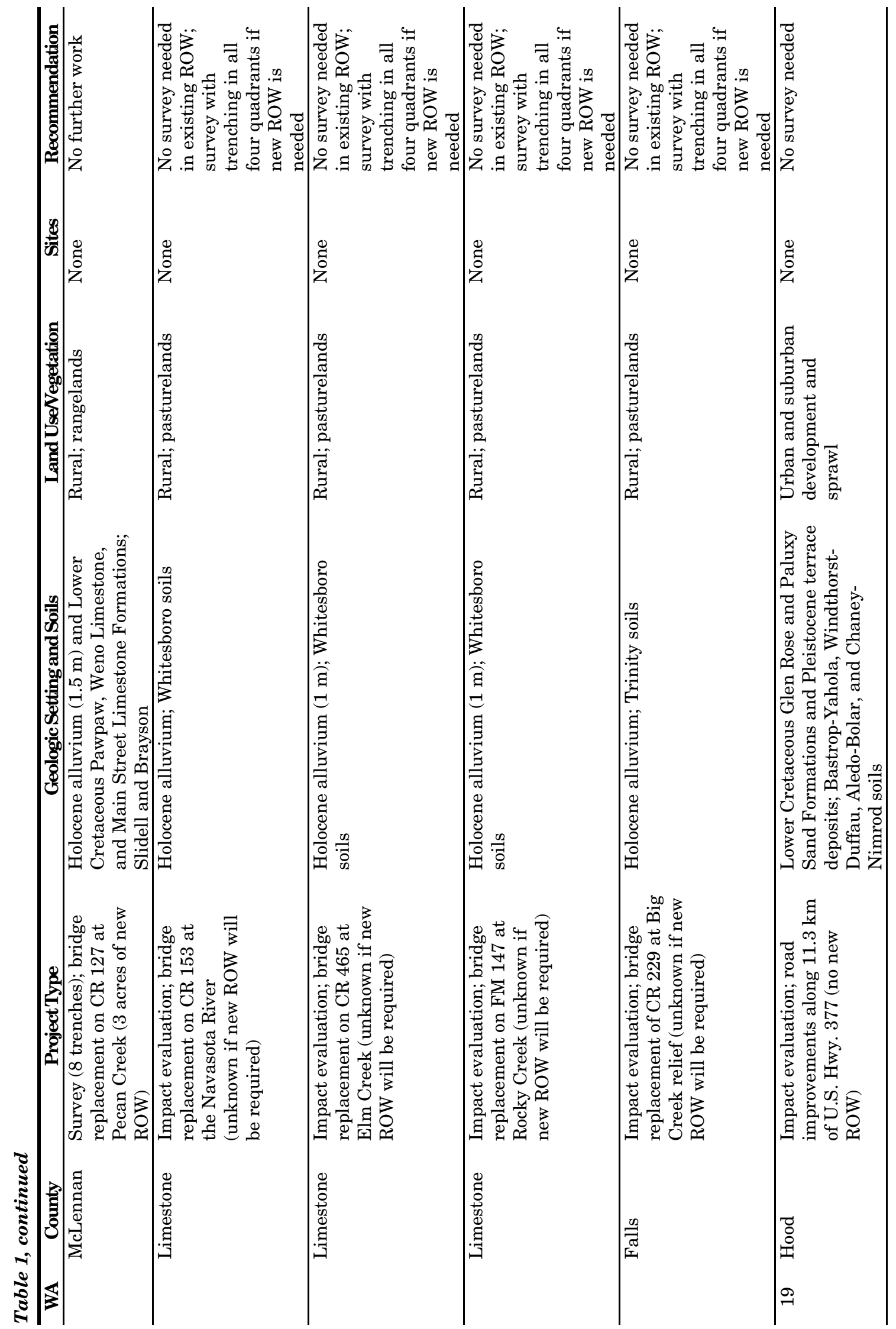




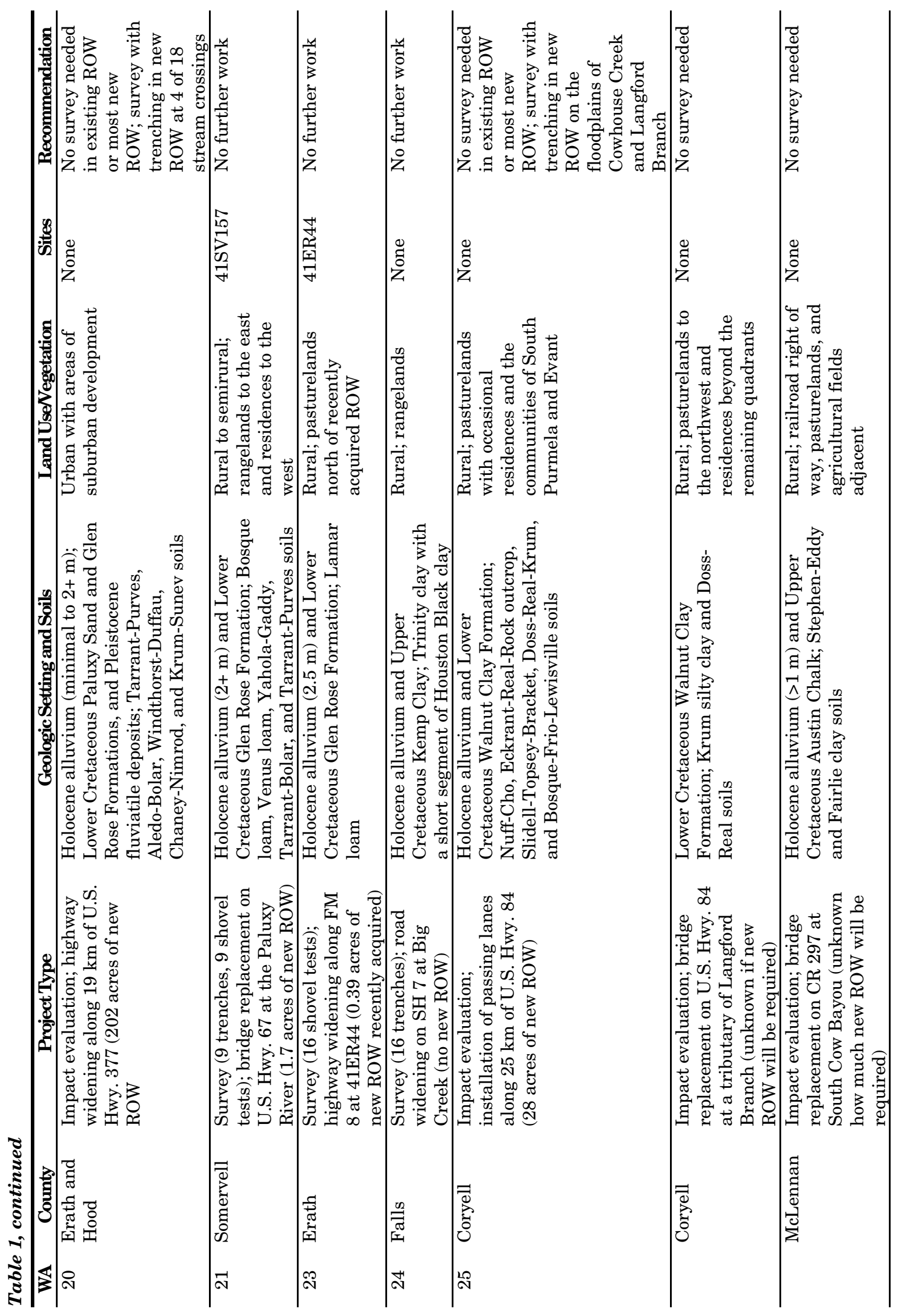




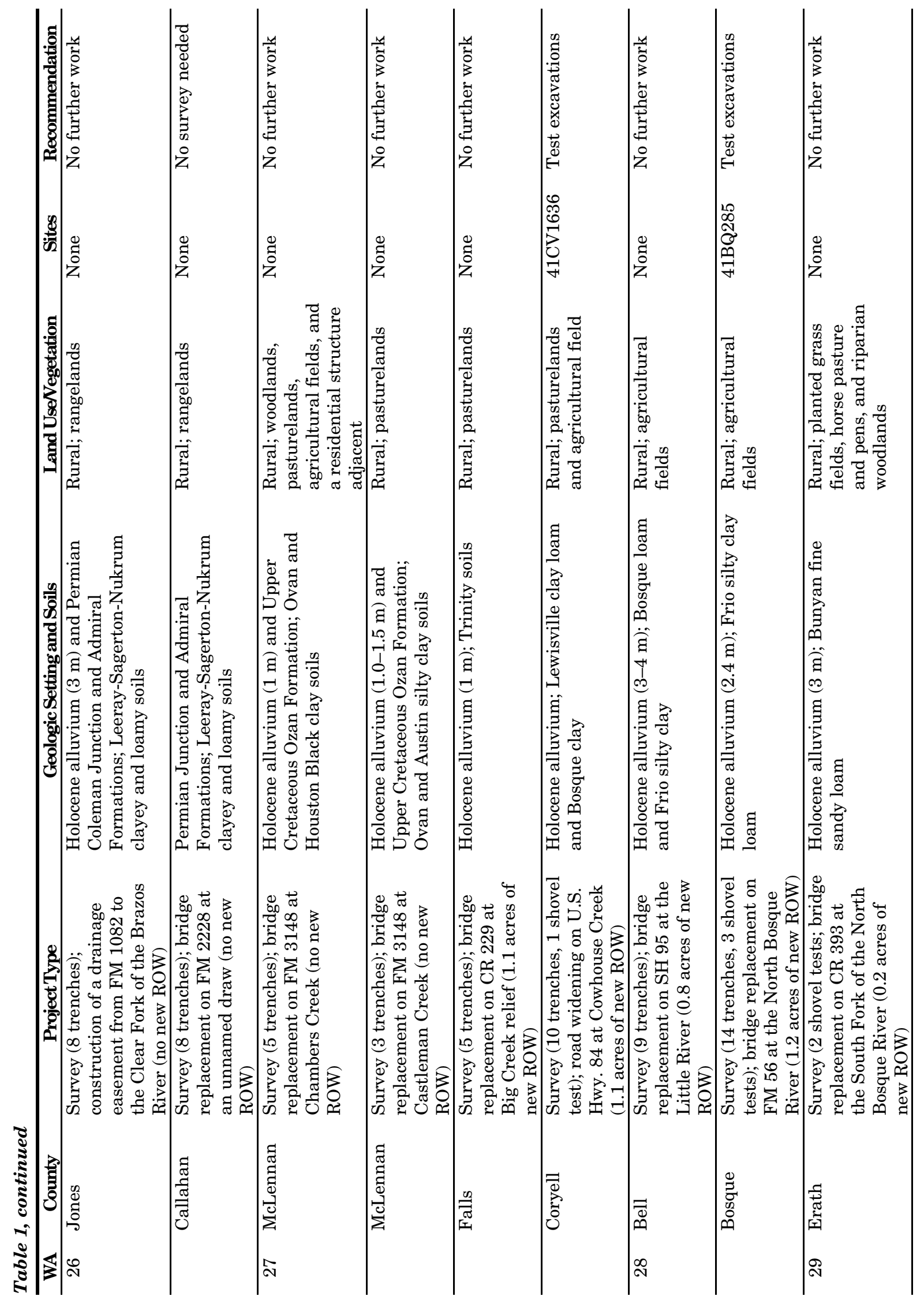




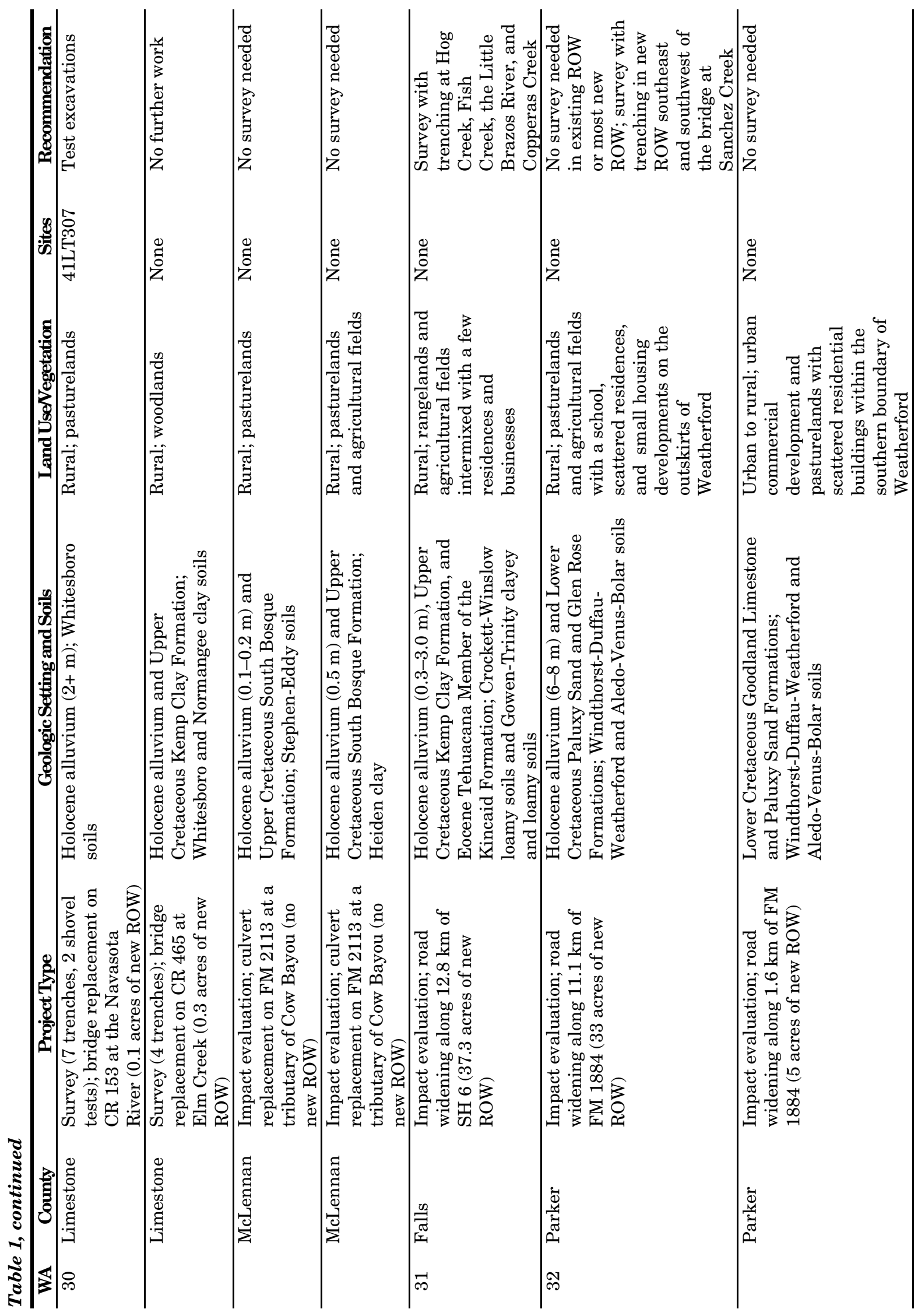




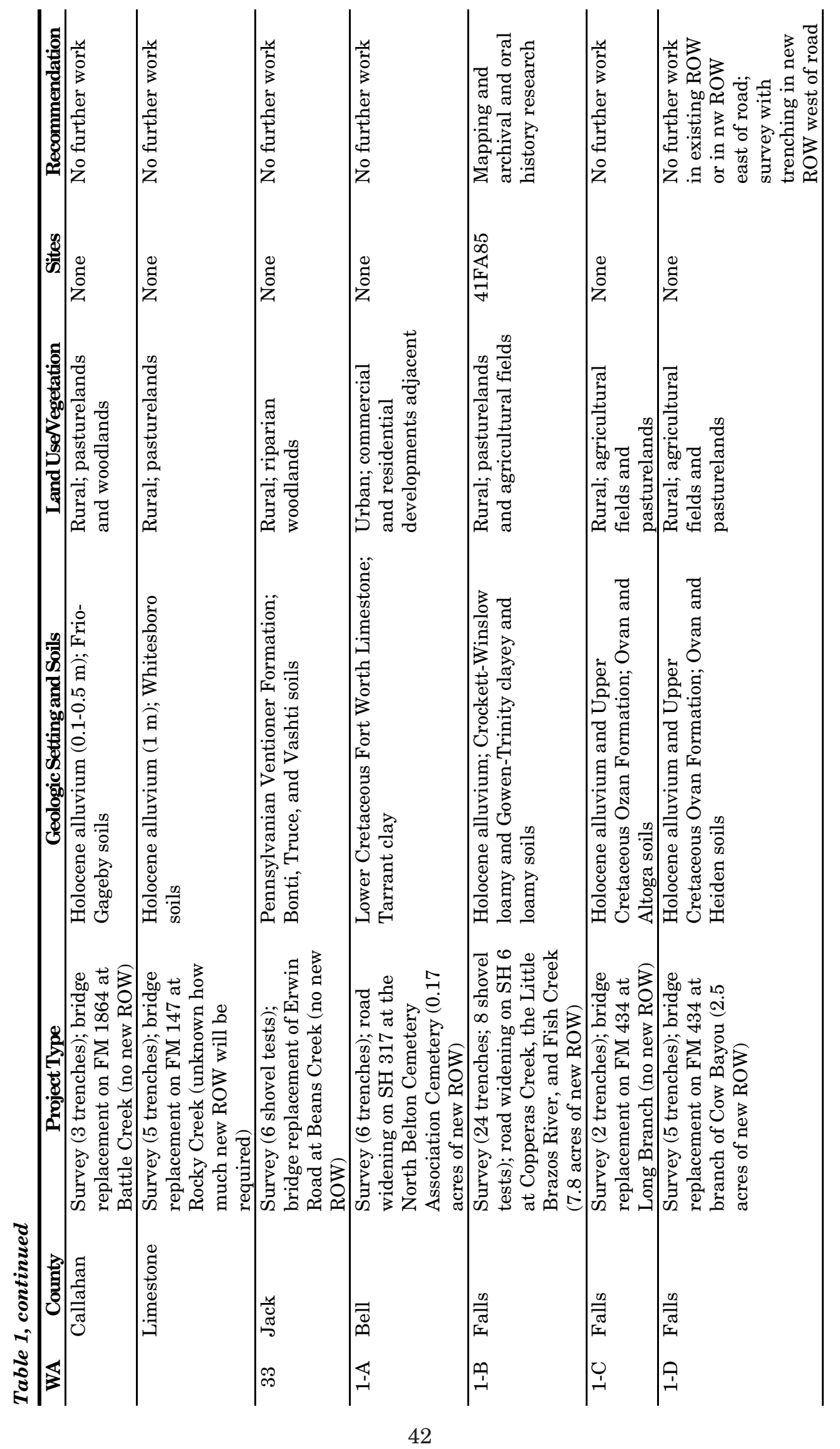




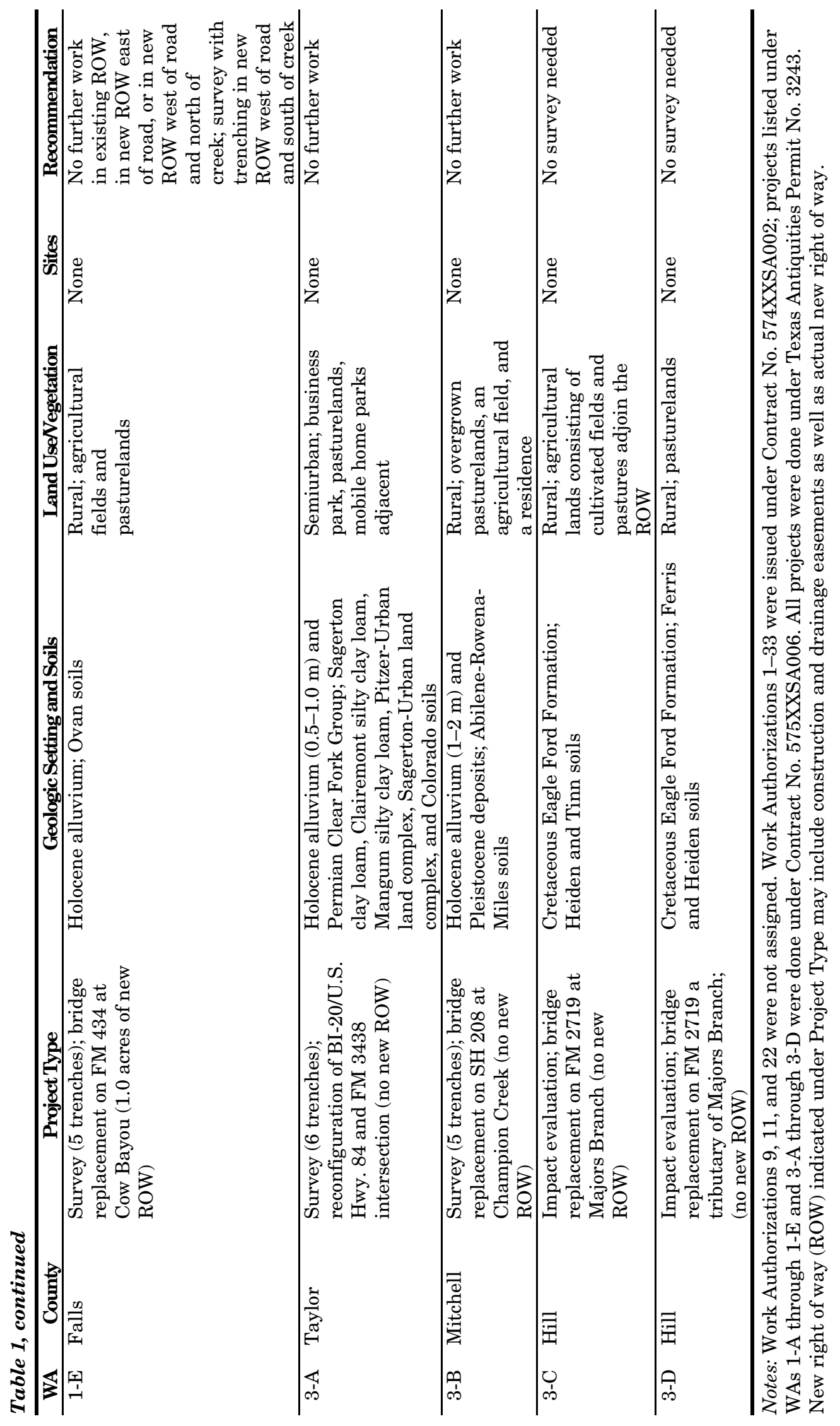


Five of the projects, most involving bridge replacements, were restricted to settings mapped as Holocene alluvium (see Table 1). Another 23 Impact Evaluations and Surveys encompassed upland margins as well as Holocene alluvium, with the uplands mapped as a variety of Mississipian (Ranger Limestone and Placid Lake), Pennsylvanian (Canyon Group, Ventioner, and Winchell), Permian (Clear Fork, Quartermaster, and Whitehorse Sandstone), Triassic (Dockum Group), Cretaceous (Comanche Peak, Eagle Ford, Edwards Limestone, Glen Rose, Kemp Clay, Kiamchi Clay, Main Street, Malbrook Marl, Nacatoch Sand, Neyland, Ozan, Paluxy, and Woodbine), and Eocene (Kincaid, Midway Group, Tehuacana, and Wills Point) deposits, as well as Pleistocene fluviatile terrace deposits. The 49 projects that were mostly in upland areas crossed the Pennsylvanian Cedarton Shale, Strawn Group, and Winchell Limestone Formations; Permian Admiral and Coleman Junction Formations; Lower Cretaceous Denton Clay, Duck Creek Limestone, Fort Worth Limestone, Glen Rose, Goodland Limestone, Paluxy Sand, Pawpaw, Walnut Clay, and Weno Formations; Upper Cretaceous Austin Chalk, Eagle Ford, Lake Waco, Kemp Clay, and South Bosque Formations; Eocene Kincaid Formation; and Pleistocene Quaternary deposits.

A variety of soils are mapped for the project areas, ranging from sandy to clayey, sometimes stony, often shallow soils in the western part of the study area to dark, calcareous, clayey soils of the Blackland Prairie. Mapped Holocene alluvial soil series in the areas examined during these work authorizations include Bastrop, Bosque, Branyon, Bunyan, Cho, Clairemont, Colorado, Decordova, Frio, Gageby, Gowen, Lincoln, Minwells, Nukrum, Olton, Ovan, Paluxy, Pulexas, Rioconcho, Sagerton, Spur, Tinn, Trinity, Venus, Whitesboro, Yahola, and Yomont (see Table 1). Upland and old terrace soils in these areas include Abilene, Aledo, Altoga, Austin, Bolar, Brackett, Crockett, Denton, Doss, Duffau, Eckrant, Eddy, Fairly, Ferris, Gaddy, Heiden, Houston Black, Krum, Latom, Leeray, Lewisville, Miles, Navo, Nimrod, Nuff, Owens, Purves, Queeny, Quinlan, Real, Rowena, Slidell, Stephen, Sunev, Tarrant, Topsey, Truce, Waurika, Weatherford, and Windthorst.

Most of the Impact Evaluations and Surveys $(\mathrm{n}=63)$ were in rural areas where adjoining lands were undeveloped and usually in pastures, agricultural fields, or woods (see Table 1). Four projects were in settings that can be classified as semirural (i.e., largely undeveloped but near low-density residential or commercial areas) or mixed rural and suburban. Two projects were in settings described as suburban (recent largescale housing developments mixed with largescale commercial development). Eight project areas were in urban or semiurban settings (i.e., the communities of Abilene, Belton, Fort Worth, Granbury, Grapevine, Killeen, Tolar, and Weatherford).

\section{IMPACTS AND SITE POTENTIAL}

A primary thrust of the Surveys and especially the Impact Evaluations performed under this contract was documentation of existing disturbances that would affect the potential of each project area to contain archeological sites with sufficient integrity to be eligible for listing in the National Register of Historic Places or designation as State Archeological Landmarks. In general, four kinds of disturbances were observed consistently within existing rights of way: fill sections, ditches, gullies, and underground utilities (Figure 5).

Fill sections to elevate the approaches to bridges above the adjoining floodplains were present at 63 , or 82 percent, of the areas investigated (Table 2). These fill sections ranged from $0.2 \mathrm{~m}$ thick to as much as $10 \mathrm{~m}$. Horizontally, they extended as little as a few meters from each end of a bridge to as much as several hundred meters, depending on the size of the valley and the kind of road. The higher and longer fill sections tended to be associated with the larger roads and larger streams. Typically, fill sections extended at least several meters beyond the edges of the pavement, in some cases occupying almost all of the existing right of way. It is difficult to quantify how much disturbance is associated with the placement of fill sections, but it is assumed that at least the upper $0.5 \mathrm{~m}$ of sediment beneath and beside fill sections is disturbed by heavy machinery during construction and later by compaction. Presumably, the larger the fill section, the deeper the disturbance.

In most cases, fill sections were bordered on both sides by shallow drainage ditches (see Table 2). These were found at 71 percent of the project areas. They usually were less than $1 \mathrm{~m}$ deep, 


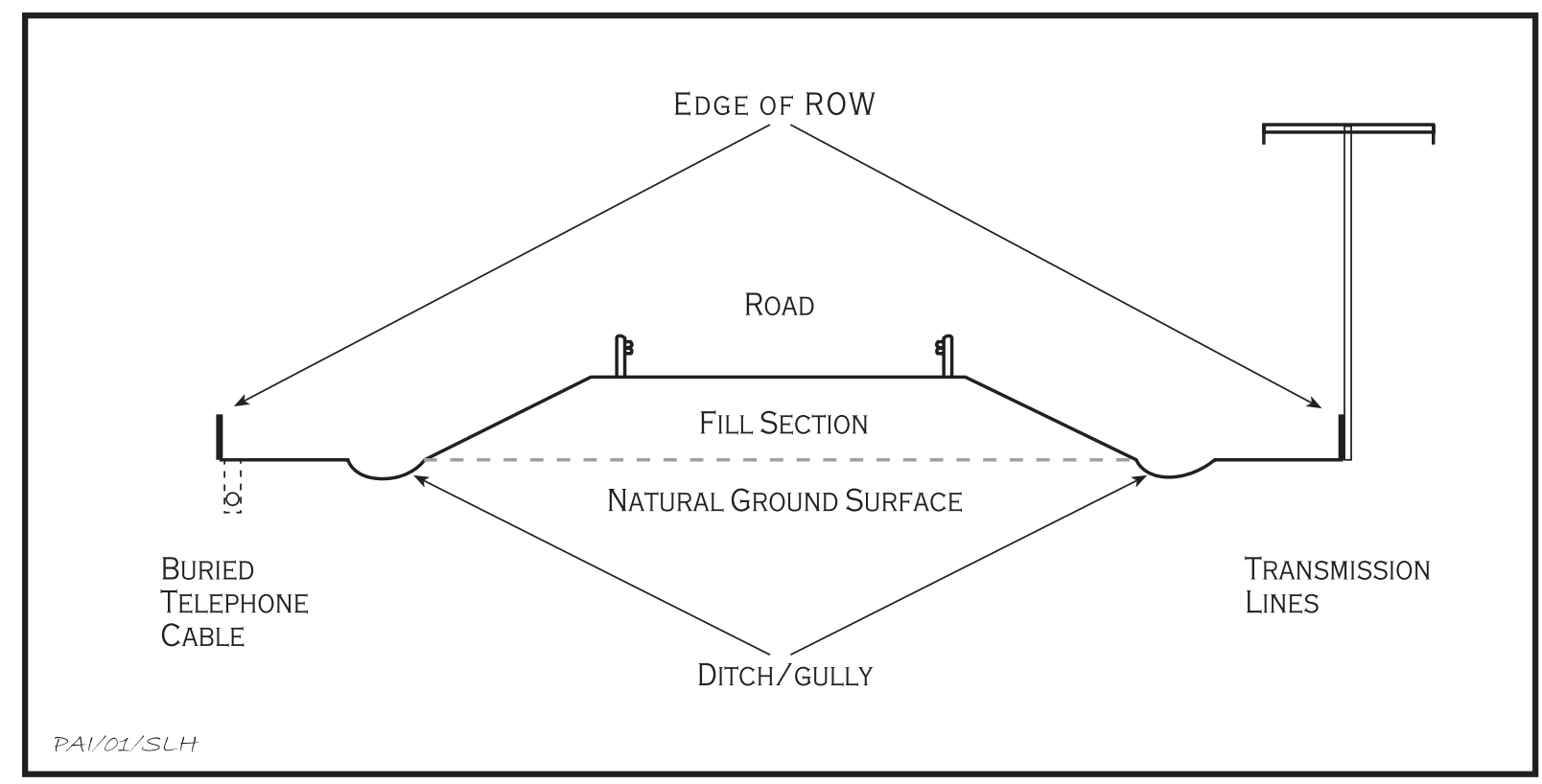

Figure 5. Schematic cross section of a bridge approach showing common disturbance factors.

and often less than $0.5 \mathrm{~m}$, and they were up to several meters wide. Vegetation covered many of them, and thus they did not offer much subsurface visibility, but some that recently had been maintained exposed subsurface deposits. In some of the more-developed areas, the ditches were lined with concrete. Better exposures sometimes were provided by gully erosion, which occurred in 45 percent of the project areas. Gullying was observed often in the bottoms of ditches running along the edges of fill sections and breaching the creek banks. In many cases, such gullies were present at one or more corners of a bridge, often extending to depths of $1 \mathrm{~m}$ or more (see Table 2).

The fourth kind of disturbance observed consistently was underground utilities. These were present in at least 71 percent of the project areas, with the most common kind being buried telephone or fiber optic lines (see Table 2). These almost always were at one or both edges of the existing right of way and were marked by signs or areas of recent disturbance from placement of the lines. Based on the extent of the recent disturbance, it appears that trenching for these lines usually had disrupted an area $0.5 \mathrm{~m}$ or less in width, although vegetation grubbing and wheel rutting often had disturbed wider areas. Presumably, they vary in depth, with most probably being no deeper than $1 \mathrm{~m}$. More-extensive disturbance probably is associated with other kinds of underground utilities, including water lines, sewer lines, gas lines, and petroleum pipelines. These were not as ubiquitous as telephone and fiber optic lines, although some (especially water lines) may not be marked with signs as consistently as telephone and fiber optic lines.

A variety of other disturbances were noted less frequently (see Table 2). These included the following: road cuts; abandoned road beds; extensive cut bank erosion; gravel quarrying; flood scouring; adjacent railroad beds (existing and abandoned); two-track roads; plowing; terracing; construction of berms; earthmoving; brush and tree clearing; adjacent commercial and residential development; construction of stock tanks; creek channelization; flood basin construction; extensive sheet erosion; fill placement; and gully filling. Sixty-one percent of the project areas had one or more of these kinds of disturbances. Overhead transmission and telephone lines, which were observed along the edges of the rights of way at many locations, occurred more frequently but caused little disturbance.

\section{SITES INVESTIGATED}

Ten archeological sites were investigated during nine work authorizations. In 4 of the 10 cases, work was restricted to existing rights of way. Descriptions of these sites, drawn from the original reports included on CD-ROM in Appendix B, are 


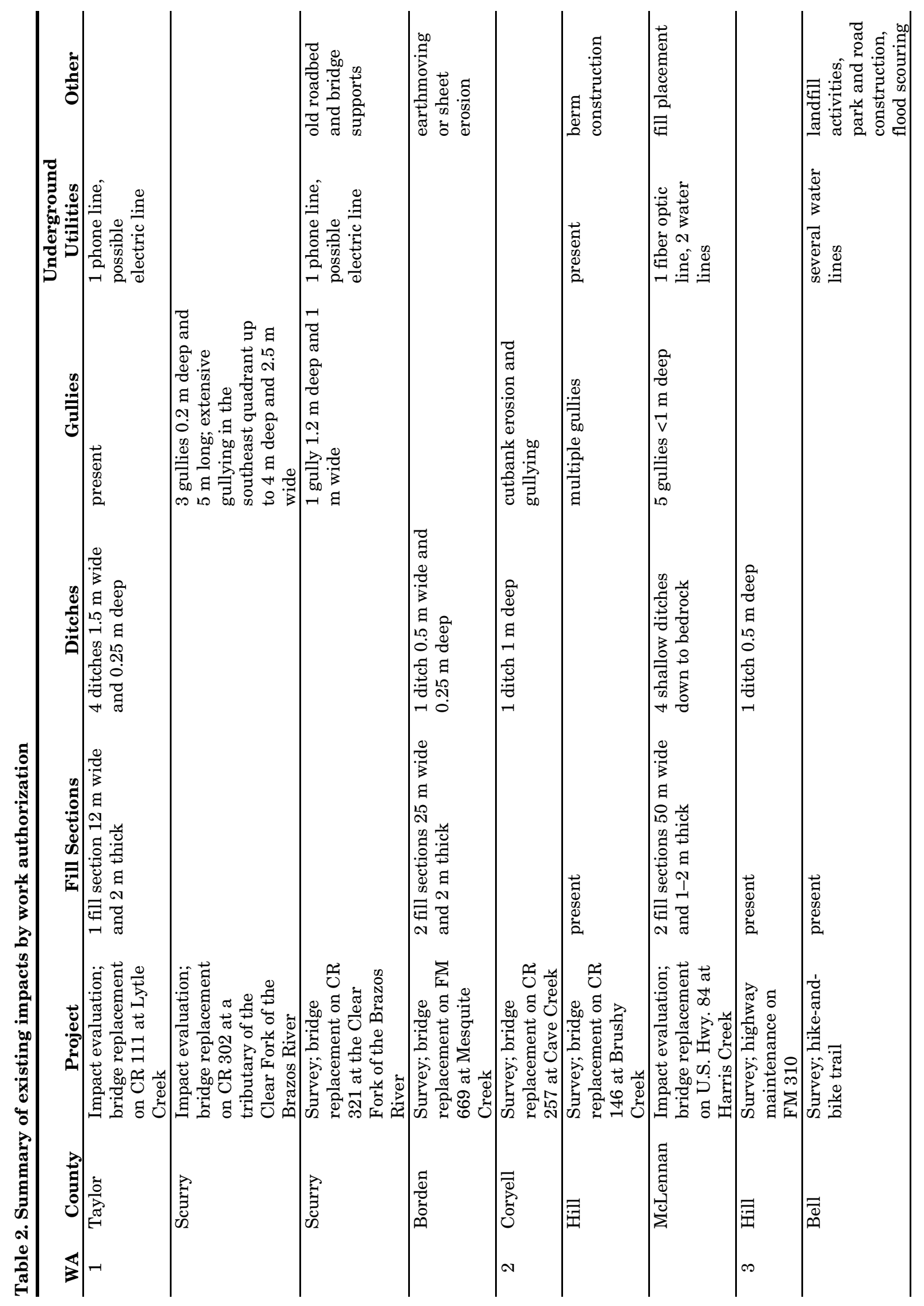




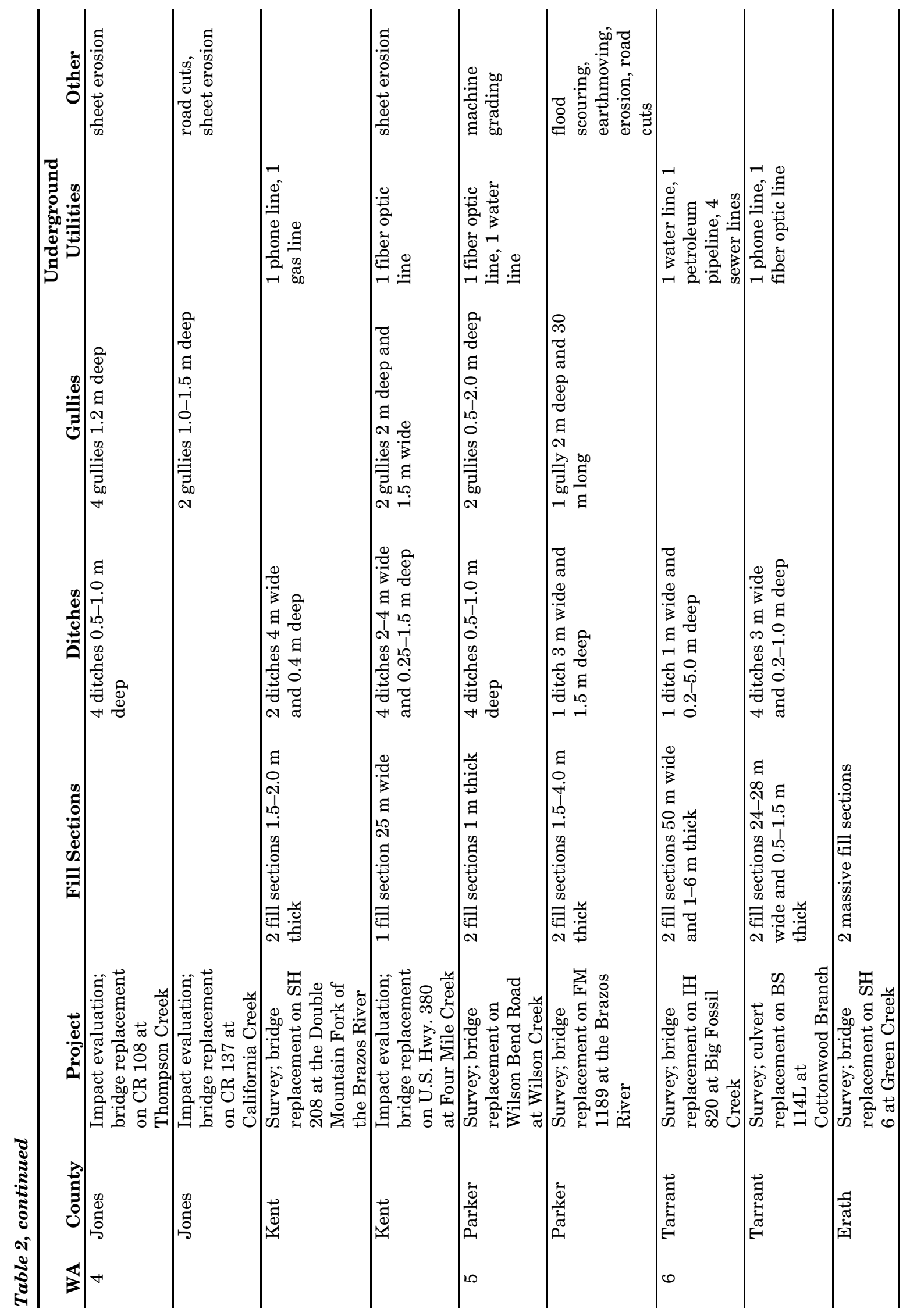




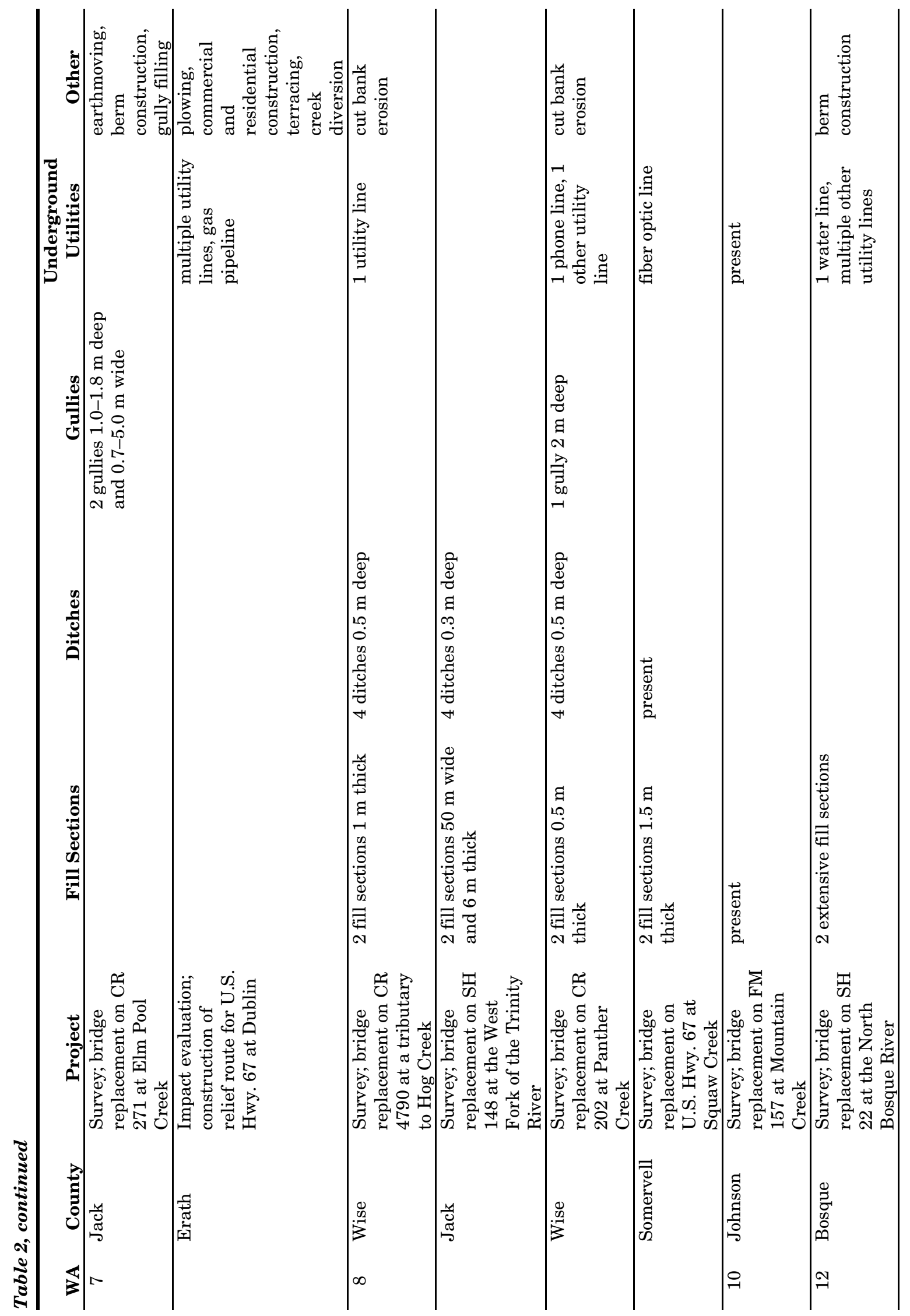




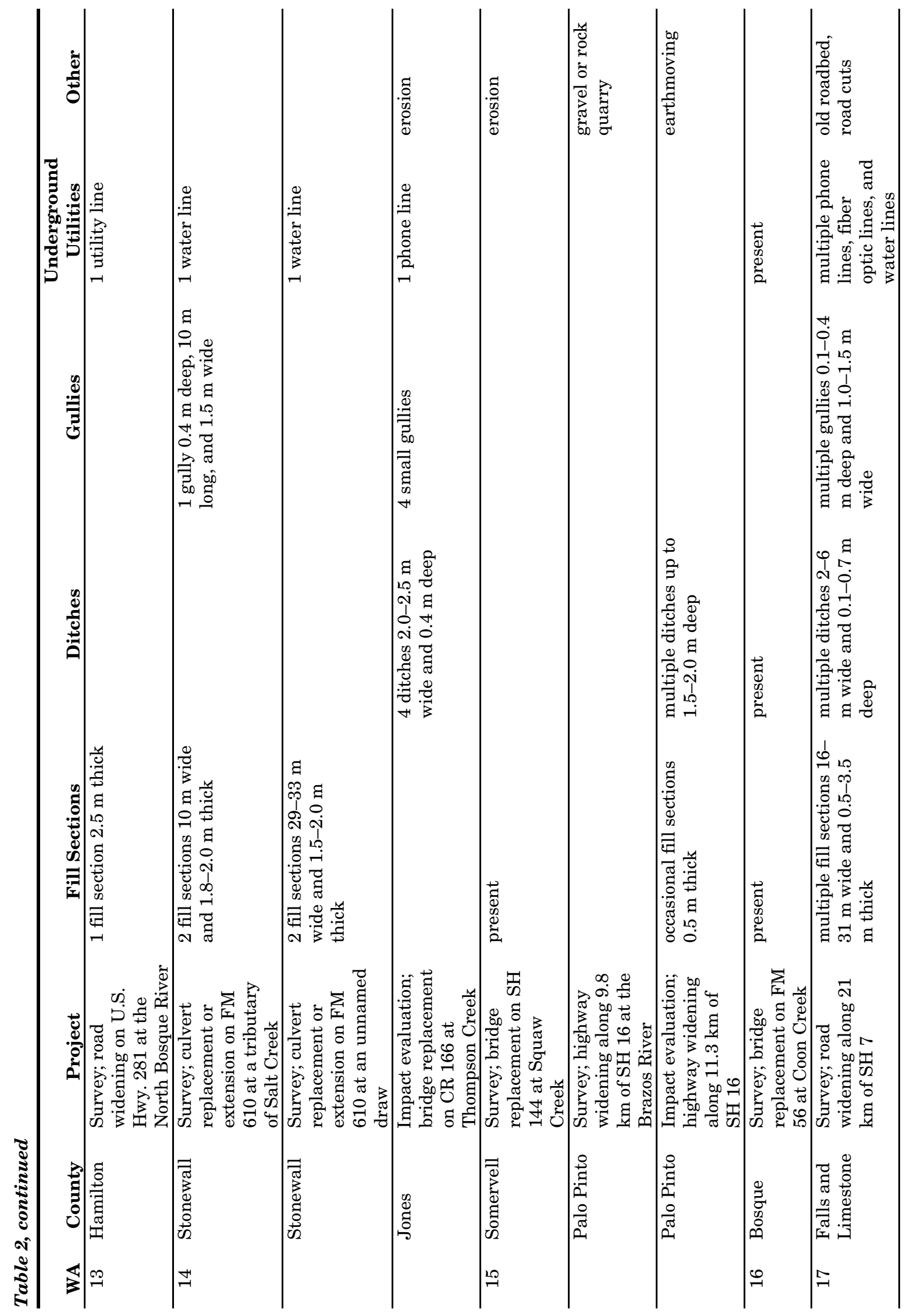




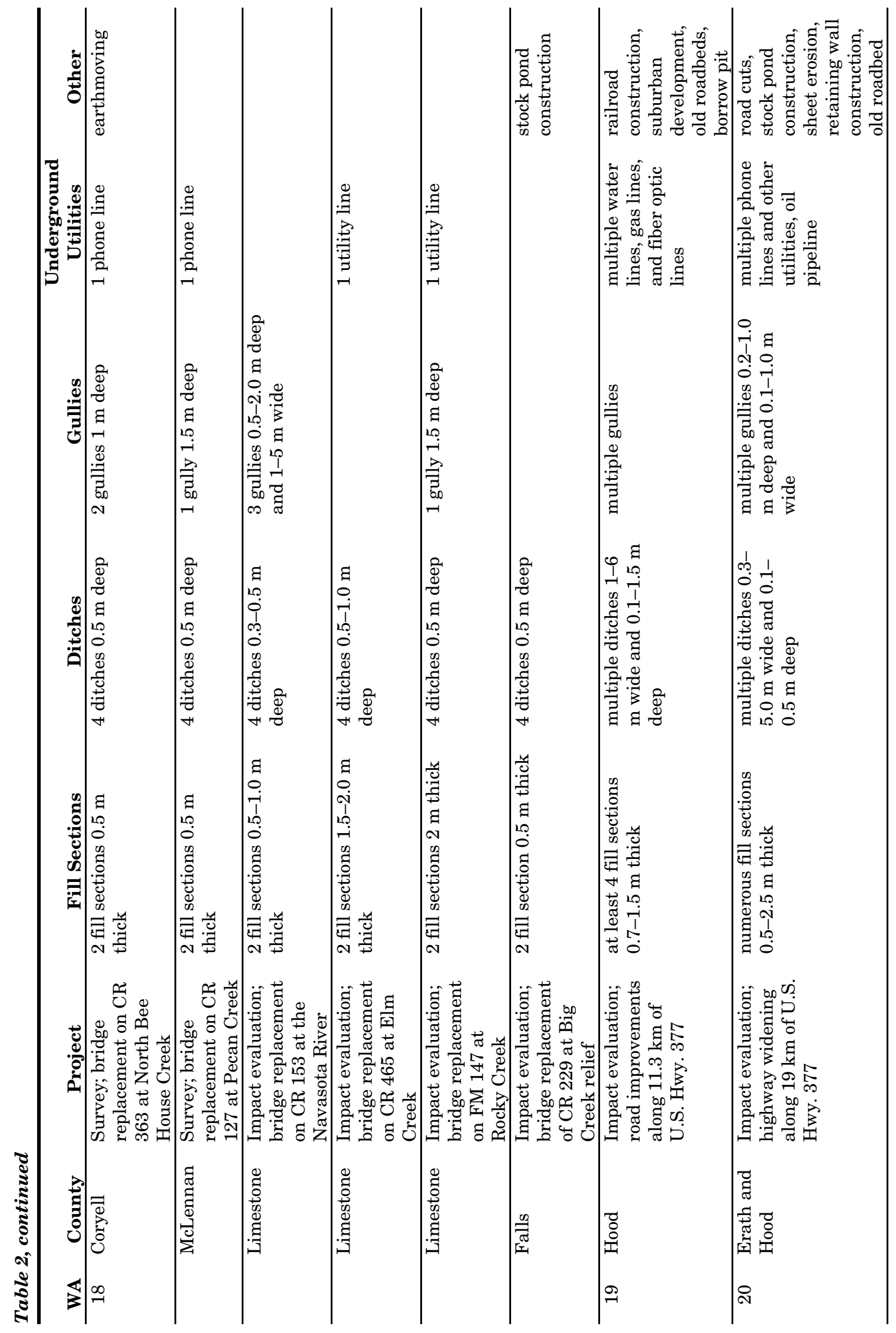


Chapter 3: Summary of Impact Evaluations and Surveys

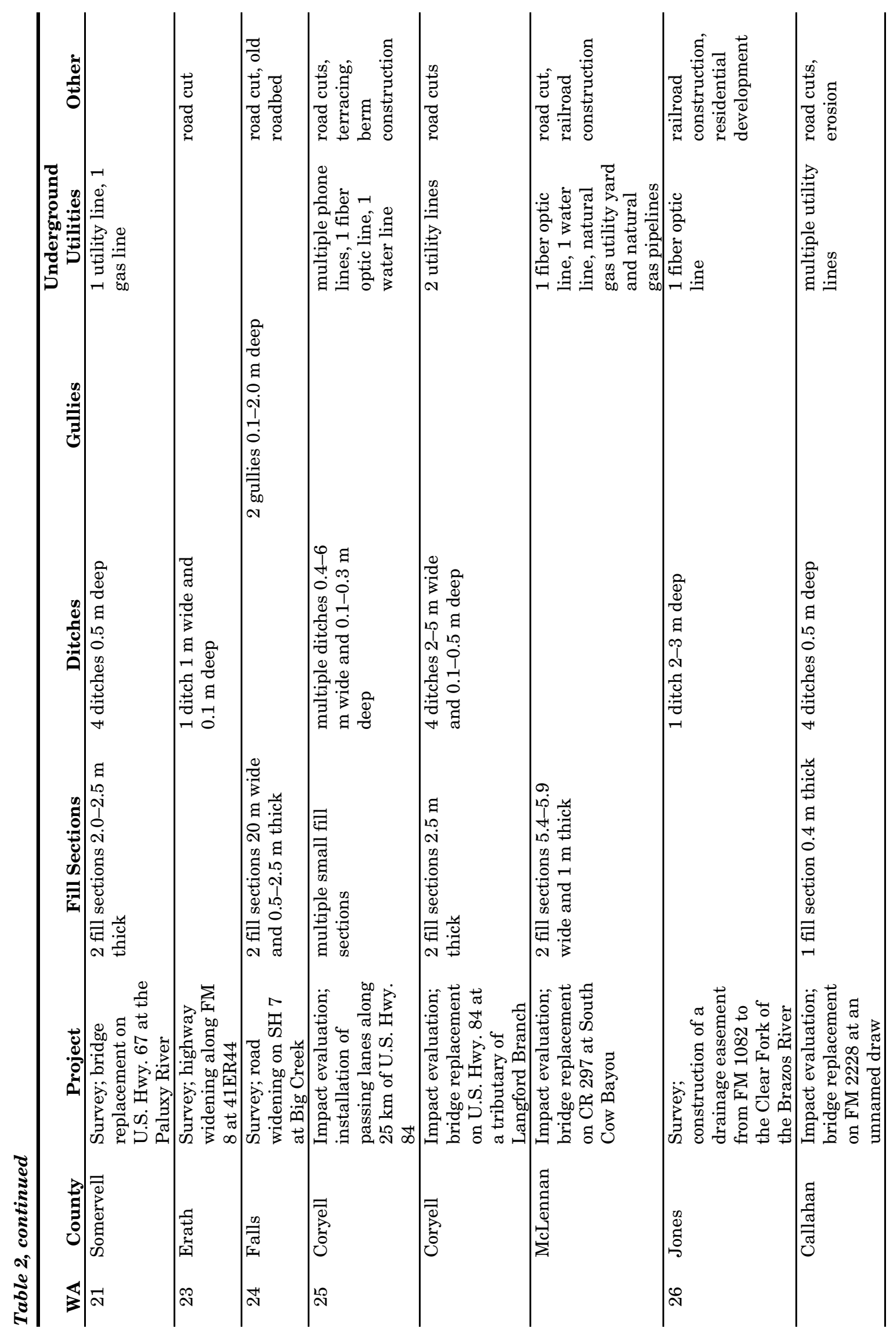




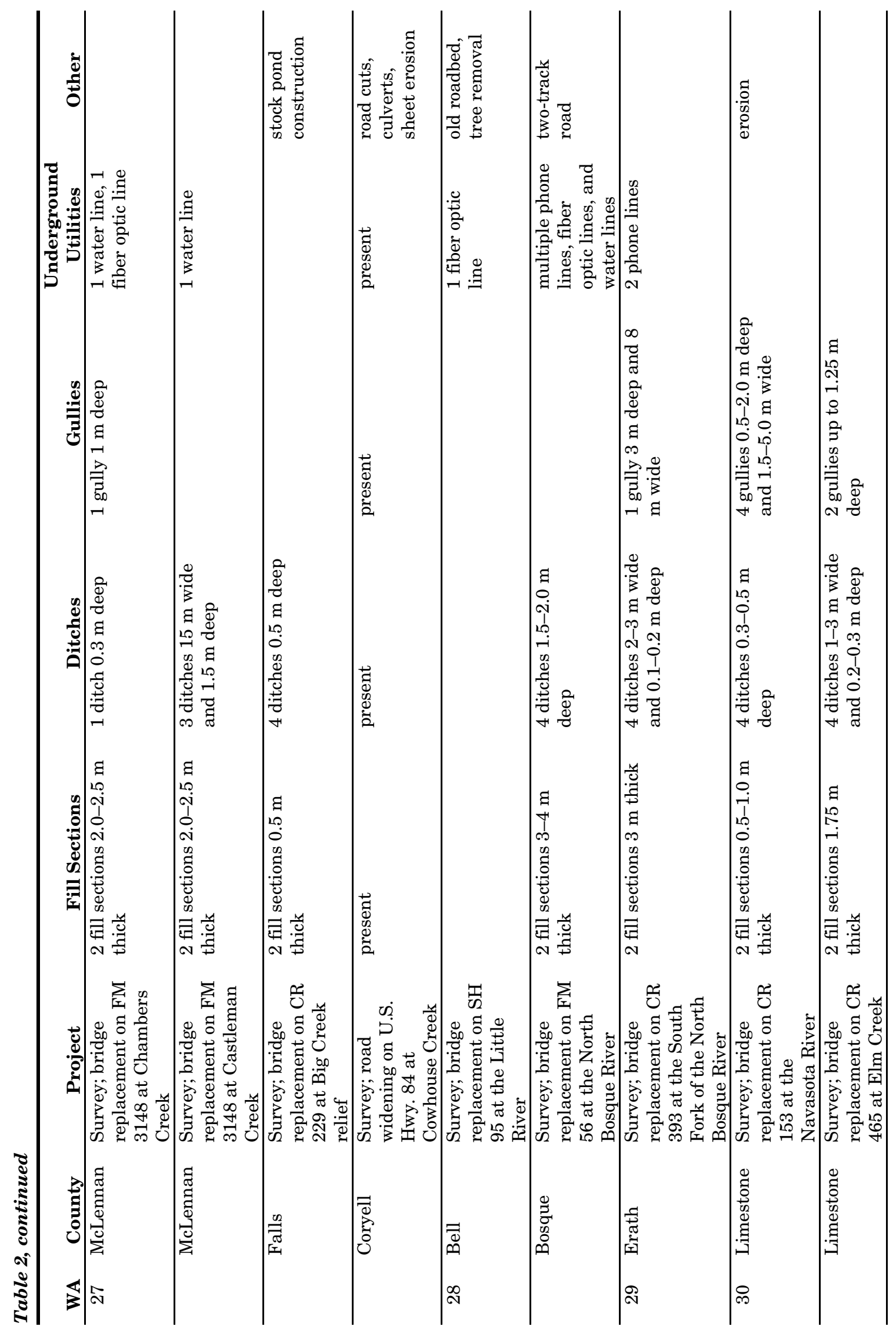


Chapter 3: Summary of Impact Evaluations and Surveys

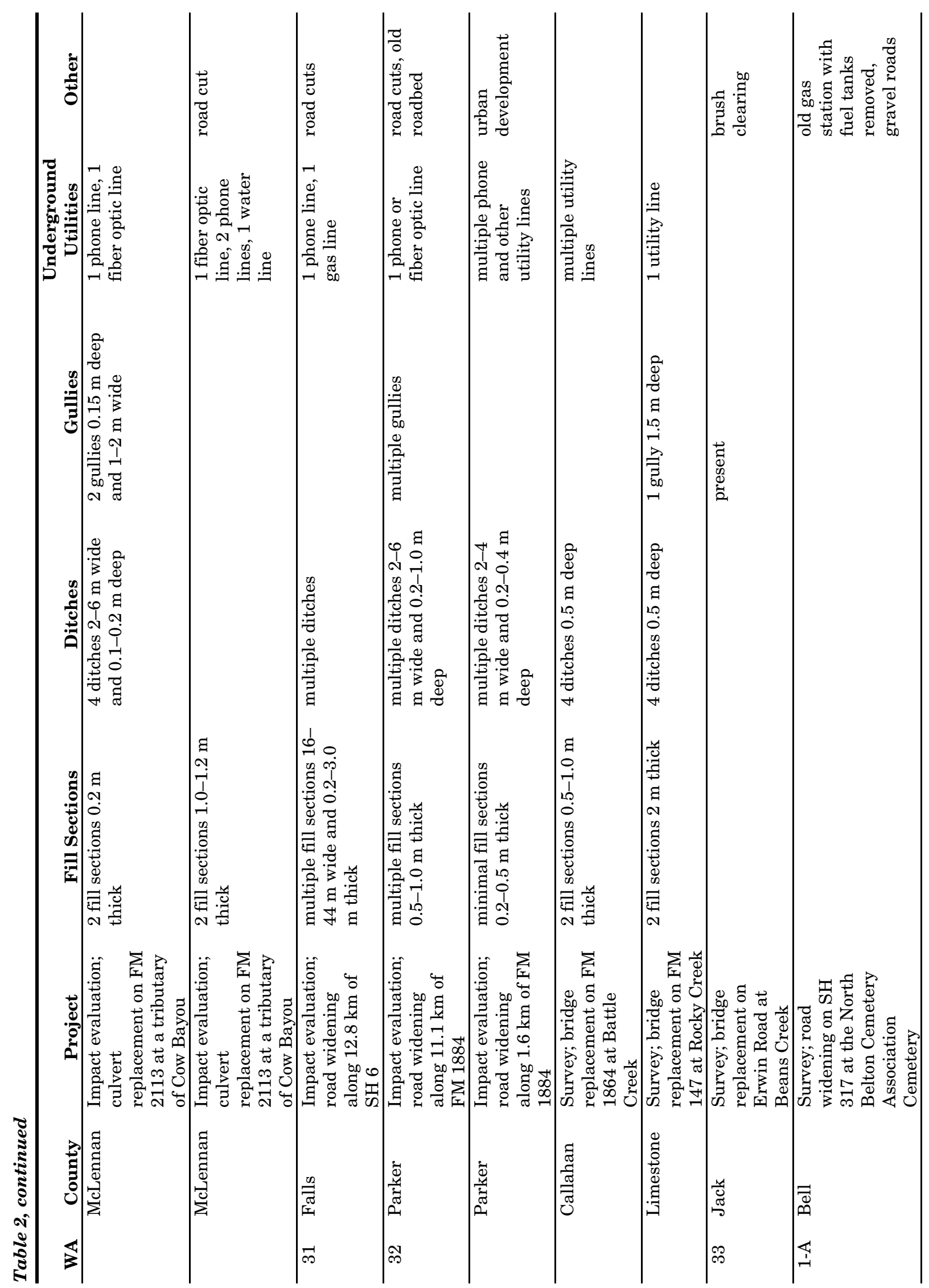




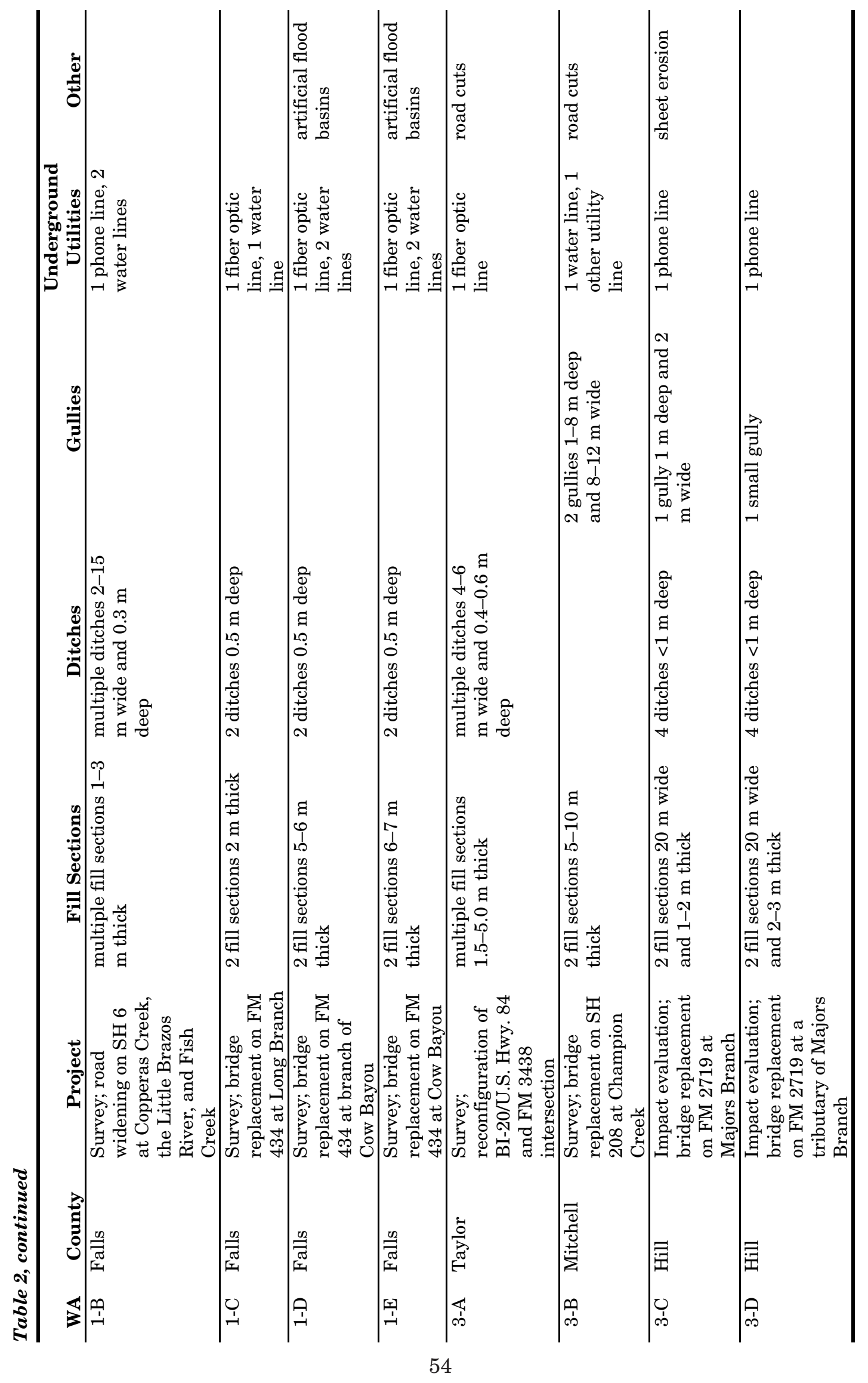


presented below. Table 3 summarizes the materials observed and recommendations made.

\section{BQ285, Work Authorization 28}

One buried prehistoric site (41BQ285) was recorded in the new right of way during a survey for a bridge replacement on FM 56 at the North Bosque River in southern Bosque County. The newly recorded site was identified along the northern side of FM 56 on the western terrace of the North Bosque River. Survey consisted of visual inspection of the surface and deep cut banks along the river channel accompanied by the excavation of 14 backhoe trenches and 3 shovel tests. Trenches 1-4 were placed in the new and existing right of way on the floodplain in the southwest and southeast quadrants of the project area with negative results. Backhoe Trenches 5-13 and Shovel Tests 1-3 were placed in the northwest quadrant on private land inside the new right of way on an upper terrace. Trenches 5-7 and 12 and all 3 shovel tests contained cultural materials and revealed similar stratigraphic profiles and sediments. The upper $10-25 \mathrm{~cm}$ consisted of a sandy silty clay topsoil. This zone contained no cultural materials. Zone 2 between 25 and $80 \mathrm{~cm}$ consisted of a silty clay loam (10YR 3/4) and contained dense burned rocks, mussel shells, debitage, animal bones, and charcoal concentrated between 28 and $68 \mathrm{~cm}$. A 40x40-cm burned rock hearth feature was uncovered at ca. $60 \mathrm{~cm}$ in the north end of Trench 12. A light scatter of mussel shells and burned rocks was located between 75 and $80 \mathrm{~cm}$.

Shovel Tests 1-3 were placed on the walls of Trenches 5, 6, and 12 to better document the artifact densities and distributions. Shovel Test 1 was dug to $140 \mathrm{~cm}$ and contained 20 burned rocks, 10 pieces of debitage, 9 mussel shell fragments, 3 pieces of bone, and charcoal at 20-40 $\mathrm{cm}$. Next, between 40 and $60 \mathrm{~cm}, 4$ mussel shells, 6 pieces of debitage, 3 bone fragments, and 1 prehistoric ceramic sherd were recovered. Between 60 and $80 \mathrm{~cm}, 2$ pieces of debitage, 1 mussel shell, and 1 burned rock were found. One piece of chert with cortex and 1 bone fragment were recovered at $80-100 \mathrm{~cm}$. No cultural materials were encountered between 100 and $140 \mathrm{~cm}$.

Table 3. Summary of archeological sites investigated

\begin{tabular}{|c|c|c|c|c|}
\hline Site & WA & Materials Observed & $\begin{array}{l}\text { Potential for } \\
\text { Intact Buried } \\
\text { Deposits* }\end{array}$ & Recommendation \\
\hline $41 \mathrm{BQ} 285$ & 28 & $\begin{array}{l}\text { Debitage, burned rock, mussel shell, animal } \\
\text { bone, charcoal, ceramic sherd }\end{array}$ & High & Test excavations \\
\hline $41 \mathrm{CV} 1636$ & 27 & $\begin{array}{l}\text { Debitage, fire-cracked rock, dart points } \\
\text { (Pedernales and Bulverde), mussel shells, } \\
\text { burned rock clusters }\end{array}$ & High & Test excavations \\
\hline $41 \mathrm{ER} 44$ & 23 & $\begin{array}{l}\text { Patinated glass (bottle, window, and chimney), } \\
\text { whiteware, earthenware, metal farm pieces, } \\
\text { brick fragments }\end{array}$ & Low & No further work \\
\hline 41FA85 & $1-\mathrm{B}$ & $\begin{array}{l}\text { Window glass, undecorated whiteware, brick } \\
\text { fragments, cut nails, metal fragments }\end{array}$ & Moderate & $\begin{array}{l}\text { Archival and } \\
\text { oral history } \\
\text { research }\end{array}$ \\
\hline 41HM53 & 13 & $\begin{array}{l}\text { Debitage, untyped dart points, unidentified } \\
\text { bone, mussel shell fragments, two burned rock } \\
\text { features }\end{array}$ & High & No further work \\
\hline 41LT307 & 30 & Debitage, Darl dart point, burned rock & High & Test excavations \\
\hline $41 \mathrm{SV} 4$ & 8 & $\begin{array}{l}\text { Debitage, Axtell dart point, tested cobble, } \\
\text { ground stone, hammerstone, bone, burned } \\
\text { rock, burned rock accumulations, rock-lined } \\
\text { basin }\end{array}$ & Moderate & $\begin{array}{l}\text { No survey } \\
\text { needed }\end{array}$ \\
\hline 41SV51 & 8 & Limited material including burned rocks & Low & $\begin{array}{l}\text { No survey } \\
\text { needed }\end{array}$ \\
\hline 41SV153 & 15 & Debitage, burned rock, charcoal & High & Test excavations \\
\hline 41SV157 & 21 & Debitage, mussel shell, burned rock & Low & No further work \\
\hline
\end{tabular}


Shovel Test 2 was placed on the wall of Trench 6 and dug to $140 \mathrm{~cm}$. The upper $20 \mathrm{~cm}$ contained no cultural materials. Level 2, between 20 and $40 \mathrm{~cm}$, contained 3 burned rocks, 1 piece of bone, and 1 mussel shell. One burned rock, 1 small bone fragment, and 1 mussel shell were found at $40-60 \mathrm{~cm}$. Next, between 60 and $80 \mathrm{~cm}$, only 1 mussel shell fragment and 1 small burned rock were encountered. No cultural materials were observed between 80 and $140 \mathrm{~cm}$. Shovel Test 3 was placed on the wall of Trench 12 and was dug to $140 \mathrm{~cm}$. No cultural materials were encountered between 0 and $40 \mathrm{~cm}$. Between 40 and $60 \mathrm{~cm}, 4$ pieces of debitage, 2 mussel shells, 1 piece of ochre, and 10 bone fragments were recovered. Next, between 60 and $80 \mathrm{~cm}$, only 1 burned rock was recorded. No cultural materials were observed between 80 and $140 \mathrm{~cm}$.

Trench 13 was placed ca. $5 \mathrm{~m}$ north of the river channel and ca. $25 \mathrm{~m}$ south of Trench 12 inside the new right of way. At ca. $40-50 \mathrm{~cm}$ an unmarked abandoned utility line was struck. Excavation of the trench was then terminated. No cultural materials were encountered in this trench, and 41BQ285 appears not to extend this far south. Trenches 8-11 were all placed north of 41BQ285 inside the new right of way. These trenches ranged between 170 and $182 \mathrm{~cm}$ deep. They all exposed silty clays and silty clay loams. No cultural materials were encountered in any of them. Finally, Trench 14 was placed in the northeast quadrant of the project area. No cultural materials were encountered.

In summary, Site 41BQ285 consists a dense accumulation of cultural materials between 28 and $60 \mathrm{~cm}$ and a sparser scatter between 60 and $80 \mathrm{~cm}$. Cultural materials consisting of burned rocks, mussel shells, bones, debitage, a ceramic sherd, and charcoal were recorded. The sherd and the fact that the site is shallowly buried suggest that the cultural materials date to the Late Prehistoric period, and the presence of charcoal indicates that the deposits are datable. An intact hearth feature located in Trench 12 containing burned rocks, bones, and charcoal suggests that the site contains undisturbed deposits. Its full dimensions are not known, since it almost certainly extends westward beyond the boundaries of the current project area. Within the proposed new right of way, the site measures ca. $50 \mathrm{~m}$ north-south and is restricted to the higher terrace. The site appears to have the potential to contribute important information, and thus it may be eligible for listing in the National Register of Historic Places under Criterion D (36 CFR 60.4) and designation as a State Archeological Landmark (Chapter 26.8, Rules of Practice and Procedure for the Antiquities Code of Texas). Archeological testing to determine this was recommended.

\section{CV1636, Work Authorization 27}

Site 41CV1636 was identified during survey of proposed new right of way for widening of U.S. Highway 84 on the margin of the Cowhouse Creek floodplain in western Coryell County. Ten trenches were excavated on private land in the 762-m-long stretch in this area. Two stratigraphic zones were generally identified. Zone 1 was a dark gray or grayish brown to black clay to silty clay with many calcium carbonate veins and small nodules with a diffuse lower boundary. Zone 2 was a brown to dark gray compact clay with small to larger nodules of calcium carbonate.

Trenches 1 and 2 were placed at the eastern end of the survey area where the new right of way first reaches its maximum width of $3 \mathrm{~m}$. One piece of stream-rolled chert was recovered from the backdirt of Trench 1 but did not appear to be culturally modified. Two pieces of fire-cracked rock were found in Trench 2-isolated within the upper $30 \mathrm{~cm}$ of the south wall-and one Rabdotus shell was found at $25-30 \mathrm{~cm}$, also in the south wall.

Trench 3 was placed $100 \mathrm{~m}$ west of Trench 2. Burned rocks were common throughout the trench, and concentrations were noted. Rabdotus shells were also observed. Zone 1 extended from 0 to $60 \mathrm{~cm}$, and Zone 2 extended to the bottom of the trench at $170 \mathrm{~cm}$. A Pedernales dart point and a Bulverde-like dart point were recovered from the backdirt pile along with $30+$ flakes, 1 blade, and 2 crude bifaces; all appeared to have come from the upper, darker matrix. The dart points were collected, and the nondiagnostic materials were returned to the backdirt after being photographed. Shovel Test 1 was excavated off the southern wall of the trench, near the eastern end. The test recovered artifacts from Levels 2-4 $(20-80 \mathrm{~cm})$, but artifacts were concentrated at $40-80 \mathrm{~cm}$. Level $2(20-40 \mathrm{~cm})$ produced 7 flakes and 4 fire-cracked rocks. Level $3(40-60 \mathrm{~cm})$ produced 56 flakes, 1 biface frag- 
ment, 1 Pedernales dart point, and 3 fire-cracked rocks. Nineteen flakes and 2 burned rocks were recovered from Level $4(60-80 \mathrm{~cm})$, and 4 flakes and 3 fire-cracked rocks were recovered from Level $5(80-100 \mathrm{~cm})$. The trench was extended $6 \mathrm{~m}$ to the east to determine how far the burned rocks continue eastward. Fire-cracked rock concentrations were noted at $40-90 \mathrm{~cm}$ along with Rabdotus and mussel shells. Lithic materials observed in the extension of the Trench 3 include 1 core, 30-40 flakes, and a third Pedernales dart point; debitage appeared to be less dense than in the western end of the trench. Scatters and concentrations of burned rock stretched ca. $12 \mathrm{~m}$ long in Trench 3, becoming less dense at the eastern end. The largest concentrations of burned rocks were ca. 1.3-3.7 m east of the western end of the trench.

Trench 6 was placed 25 m east of Trench 3 to determine if additional scatters of burned rocks stretch to the east. While excavating, two small chunks of fire-cracked rock were observed in the upper $30 \mathrm{~cm}$, three at $100-130 \mathrm{~cm}$, and two at $140 \mathrm{~cm}$. In the walls, two fire-cracked rocks were observed at $50 \mathrm{~cm}$, four at $120 \mathrm{~cm}$, and two at $153-160 \mathrm{~cm}$. Zone 1 reached to 153 $\mathrm{cm}$, and Zone 2 followed down to $1.9 \mathrm{~m}$. No cultural materials other than small burned rocks were identified in the trench walls or in the backdirt pile. Trenches 4-5 and 7-10 stretched to the west of Trench 3 within the proposed new right of way. Scattered fire-cracked rocks were observed from 20 to $120 \mathrm{~cm}$ in Trenches 4, 5, and 7. No lithic artifacts were observed despite careful cleaning of the trench walls and inspection of the backdirt.

Four dart points - three Pedernales and one Bulverde-like-were recovered from the Trench 3. Based on dart point chronology, the site appears to date to the Late Archaic period, with Pedernales points dating from 2400 to 3250 B.P. and Bulverde points being slightly older at 3250 4000 B.P. (Collins 1995).

Based on the fact that the site is buried in Holocene alluvium and has abundant cultural materials that may be isolable into discrete components, it appears to have the potential to contain important information and hence be eligible for listing in the National Register of Historic Places under Criterion D (36 CFR 60.4) and designation as a State Archeological Landmark (Chapter 26.8, Rules of Practice and Procedure for the Antiquities Code of Texas). Testing was recommended to determine this.

\section{ER44, Work Authorization 23}

Site 41ER44, a previously recorded historic site, was discovered after bulldozer clearing for installation of a fence along the edge of the new right of way for widening of FM 8 near Flat Creek in far western Erath County. Personnel from Big Country Archeology originally recorded 41ER44 for the private landowner after a historic well was exposed (Godwin 2004). Godwin recorded an artifact scatter, excavated shovel tests, and conducted archival research. Artifacts collected from the surface and shovel testing include flaked glass, an ovate unifacial scraper of aqua bottle glass, a second scraper, two utilized flakes, whiteware, crockery or earthenware sherds, bottle and window glass fragments, cut nails, a metal strap, a toothed clock gear, a handforged iron axe head, and a hand-forged hinge. Archival research and analysis of the artifact collection suggested that the site may have had a complex history relating to early frontier settlement and interaction with Native Americans. Godwin suggested that 41ER44 was potentially eligible for listing in the National Register of Historic Places and for designation as a State Archeological Landmark.

Personnel from Prewitt and Associates relocated 41ER44 and conducted an impact evaluation. Based on disturbances found within the existing right of way, it was determined that there is no potential for intact archeological deposits in the original right of way and that survey should focus on the recently acquired new right of way. Artifacts were readily visible scattered across the site within the new right of way and included over 20 pieces of highly patinated glass (brown, very dark blackish brown, clear or aqua, and oxidized), a piece of whiteware with part of a common coat of arms maker's mark, a cast iron machine piece, and a metal gate hinge. The artifact scatter stretched $20 \mathrm{~m}$ west of the well to $36 \mathrm{~m}$ east of it within the recently acquired right of way.

Sixteen shovel tests were excavated on stateowned lands within the recently acquired right of way on the north side of FM 8 adjacent to the previously recorded part of 41ER44. Shovel Tests 1-13 were placed in a zigzag pattern about $10 \mathrm{~m}$ apart between the new right of way fence line 
and the edge of the old right of way. Shovel testing began ca. $48 \mathrm{~m}$ west of the original site boundary and ended ca. $24 \mathrm{~m}$ east of it. Shovel Tests 14-16 were placed around the test that yielded the most artifacts. The tests reached depths of 5 to $46 \mathrm{~cm}$ before terminating at bedrock. Eight shovel tests were positive. Artifacts were counted and recorded by level and then returned to the shovel tests. Artifacts exposed in the shovel tests included a small fragment of red cement or brick, a piece of whiteware, two cut nails, a large earthenware base fragment, a clinker, and rusted metal. In addition, numerous pieces of highly patinated glass were exposed including a piece of very dark brown glass bottle neck, one aqua or clear highly patinated bottle base, other clear or aqua glass, brown glass, thin window glass, clear patinated chimney glass, and four very fragmentary pieces of clear glass that were rounded and appeared to have been weathered or sanded down.

Over 24 artifacts were observed scattered across the site surface within the recently acquired right of way. Shovel tests produced 37 historic artifacts, 34 of which are thought to possibly date to the nineteenth century. Historic artifacts are scattered over an area of 65 m east to west with a concentration in the center in Shovel Tests 7 and 14. Artifacts were more frequently found on the surface and in the upper $20 \mathrm{~cm}$ but also were common at $20-40 \mathrm{~cm}$; only 1 fragmentary piece of glass was found at 40-60 $\mathrm{cm}$. The revised site boundaries extend beyond those suggested by Godwin's 2004 investigations to include the new right of way and now measure $85 \mathrm{~m}$ northeast-southwest by $70 \mathrm{~m}$ northwest-southeast.

Most of the site lies outside the FM 8 right of way, although a small part extends into the 9$\mathrm{m}$-wide recently acquired right of way. The northern portion of the site contains at least one intact feature, a well that has been altered recently by bulldozing. Additional subsurface features, such as building foundations and pits, could also remain intact. However, the southern portion of the site in the recently acquired right of way does not appear to have intact features. Artifacts are scattered throughout this area, and although most of the artifacts probably date to the late nineteenth century, artifacts such as the gate hinge, a piece of red cement or brick, modern nails, and modern glass complicate the assemblage chronologically. The fact that the site lies on a well-traveled road makes it especially susceptible to the introduction of post-occupation materials. Finally, the site surface has been recently disturbed by bulldozing, and the sediments are generally shallow, reaching only 50 $\mathrm{cm}$ at most, and are therefore not conducive to subsurface feature preservation. Therefore, the southern part of 41ER44 south of the new right of way fence line and constituting the existing project area holds little research value. Because it does not contain important information, it is considered ineligible for listing in the National Register of Historic Places under Criterion D (36 CFR 60.4) or designation as a State Archeological Landmark (Chapter 26.8, Rules of Practice and Procedure for the Antiquities Code of Texas). No further work was recommended.

\section{FA85, Work Authorization 1-B}

Historic site 41FA85 was recorded during a survey for widening of SH 6 at Fish Creek in southeastern Falls County. A dilapidated house, a well, and the remains of a windmill were recorded on private land at the edge of the northern terrace of Fish Creek west of SH 6.

The house, which appears on the 1936 Falls County highway map, is a board-and-batten, pier-and-beam structure with a side gable and was originally a small one-room house and a back porch. A second, smaller room was added later based on a change in the board-and-batten styles on the exterior walls. Although most of the windows are broken, two remain partially intact, both on the south (front) side of the house. The original room has one remaining $6 / 6$ window which suggests an 1880 s-1890s date of construction. The second room has a 4/4 window suggesting a slightly later date of construction. The porch has fallen off of the piers and has almost completely collapsed. A chimney once stood on the east side of the original room but has fallen; a brick pile on the east side of the house represents the remains of the chimney. Additional brick fragments lie scattered across the site.

A brick-lined well is ca. $8 \mathrm{~m}$ east of the southeast corner of the house. The well is open, but a cylindrical concrete pipe has been placed vertically on top of the well's rim. Water is pooled at the bottom of the well. Two L-shaped metal posts flank the northern side of the well but have been 
cut or broken off and may be the remains of a windmill frame. Small, thin sheets of tin are scattered in the vicinity of the well and are probably the remains of the blades. The area around the well and to the west and south of it is very disturbed, possibly by an uprooted tree, feral hog rooting, or removal of a tank for water collection. Two round metal posts once stood near the western edge of the site spanning a distance of ca. $5 \mathrm{~m}$. The posts are broken off near the ground surface. Based on the size of the remains of the posts and their distance from one another, these may be the remains of a laundry line.

Six shovel tests were excavated around the structure and well. Artifacts were recovered from four of the six shovel tests. The tests exposed an upper light brown silty clay loam reaching 18$40 \mathrm{~cm}$ deep over a compact strong brown clay. Shovel Test 1 was $5 \mathrm{~m}$ west of the house in line with a door to the side room. It reached strong brown clay at $18 \mathrm{~cm}$. Four pieces of window glass and one undecorated whiteware sherd were recovered from the upper $20 \mathrm{~cm}$. Shovel Test 2 was $7 \mathrm{~m}$ south of the front of the house. It was negative and reached the subsoil at $24 \mathrm{~cm}$. Shovel Test 3 was $2 \mathrm{~m}$ southeast of the well and reached the subsoil at $40 \mathrm{~cm}$. Four window glass fragments, several small brick fragments, one fragment of unidentifiable metal scrap, and one whiteware sherd were recovered from the upper $20 \mathrm{~cm}$. The whiteware sherd has the upper portion of a royal coat of arms insignia. This style of maker's mark is extremely common, and no exact date can be ascertained. One small brick fragment was recovered from Level $2(20-40 \mathrm{~cm})$. Shovel Test 4 was $4 \mathrm{~m}$ northeast of the northeast corner of the house off of the back porch. The subsoil was reached at $24 \mathrm{~cm}$. Four pieces of window glass were recovered within the upper $20 \mathrm{~cm}$. Shovel Test 5 was $4 \mathrm{~m}$ northwest of the inside corner of the back porch and the room addition. It reached the subsoil at $22 \mathrm{~cm}$, and no cultural material was recovered. Finally, Shovel Test 6 was $3 \mathrm{~m}$ southeast of the front door. It reached the subsoil at $30 \mathrm{~cm}$ and exposed six pieces of window glass and one piece of metal scrap in Level $1(0-20 \mathrm{~cm})$.

The site measures $34 \mathrm{~m}$ north-south by $20 \mathrm{~m}$ east-west based on the structure and other features and the four positive shovel tests. It appears to date mostly to the first half of the twentieth century, although initial construction in the late nineteenth century is possible. Given the possibility of nineteenth-century construction and the presence of artifacts and features, it was recommended that information regarding the history and associations of the site needs to be gathered to aid in assessing its eligibility for listing in the National Register of Historic Places (36 CFR 60.4) and designation as a State Archeological Landmark (Chapter 26.8, Rules of Practice and Procedure for the Antiquities Code of Texas). Archival research involving deed, tax, and census records was recommended, along with oral history research.

\section{HM53, Work Authorization 13}

Site 41HM53, a buried prehistoric occupation site, was investigated on state-owned lands within existing right of way in northern Hamilton County. The site was originally recorded by personnel from Blanton and Associates, Inc., while conducting an archeological survey for the U.S. Highway 281 widening and bridge replacement project on the North Bosque River. At that time, the cultural deposit was identified at 100 to $140 \mathrm{~cm}$ below the ground surface in three backhoe trenches east of U.S. Highway 281 . These investigations resulted in a recommendation for further testing to investigate the site's potential for listing in the National Register of Historic Places and designation as a State Archeological Landmark. Personnel with Prewitt and Associates conducted more-intensive investigation focused on the three positive trenches followed by the manual excavation of eleven $1 \mathrm{x} 1-\mathrm{m}$ test units. The existing right of way at the site is narrow and contains a 2.5-m-thick fill section in addition to a buried utility line. These conditions allowed for only a narrow strip of undisturbed portions of 41HM53 to be investigated within the existing right of way.

Trenches 1 and 2 were located north of a slough on the North Bosque River floodplain, and Trench 3 was located south of the slough. Placement of test units was predicated on locating possible features in the floors of trenches or in areas deemed probable for containing cultural materials or features. Approximately $1 \mathrm{~m}$ of overburden was removed from each trench so that manual excavations could focus on the cultural zone previously identified at ca. $100-140 \mathrm{~cm}$ below the ground surface. The 11 test units were excavated in 10-cm levels, and the volume of 
sediment manually excavated and screened totaled $4.27 \mathrm{~m}^{3}$. Test Units $1-4$ were placed within Trench 2 to investigate Feature 1 . Test Units 5 , 6,9 , and 10 were placed within Trench 1 to investigate Feature 2 . Test Units 7, 8, and 11 were placed within Trench 3 to investigate the location of a third feature identified during the initial survey.

The deposits at 41HM53 display a C-AC-AbBwb soil profile. The $\mathrm{C}$ horizon $(0-50 \mathrm{~cm})$ is a brown (10YR 4/3) silty clay loam. The AC horizon $(50-72 \mathrm{~cm})$ is a dark grayish brown (10YR 4/2) silty clay. Both horizons represent recent alluvial deposition. A buried soil imprinted on these sediments consists of an Ab-Bwb profile. The Ab horizon (72-90 cm) is a very dark grayish brown (10YR 3/2) clay loam, while the Bwb horizon $(90-125+\mathrm{cm})$ is dark grayish brown (10YR 4/2) clay loam. Both soil horizons exhibit moderate medium blocky angular structure and encapsulate cultural materials. The Trench 2 profile displays an A-Bw soil. The A horizon (0$44 \mathrm{~cm})$ is a dark grayish brown (10YR 4/2) silty clay loam with moderate medium blocky structure. The $\mathrm{Bw}$ horizon $(44-100+\mathrm{cm})$ is a dark grayish brown (10YR 4/2) clay loam with moderate medium blocky structure.

The prehistoric cultural materials recovered in screening the sediments from the test units consist of 2 untyped dart points, 34 pieces of debitage, 4 edge-modified flakes, 5 pieces of unidentified bone, 145 fragments of mussel shell, and $26.8 \mathrm{~kg}$ of burned rocks found. Four pieces of debitage, 50 fragments of mussel shell, 14 fragments of bone, and $72 \mathrm{~g}$ of burned rocks were recovered from the heavy fractions of matrix samples collected from features for flotation. The highest number of mussel shells, 34 fragments, came from Test Unit 5. Test Unit 10 contained 2 edge-modified flakes, while Test Units 2 and 4 each contained 1 . Bone was sparse with 3 pieces coming from Test Unit 7 and 2 pieces from Test Unit 9. Burned rocks represent the greatest number of cultural materials recovered. Although scattered throughout the test units, Test Unit 2 produced 36 and Test Unit 4 produced 34 , by far the greatest numbers of burned rocks recovered from individual test units.

Two features were exposed and excavated. Feature 1 was in Test Unit 5 in Trench 2. It consisted of an amorphous concentration of burned rocks and mussel shells. Feature 2 was found in Trench 1 covering much of Test Unit 2 and into
Test Unit 1 . The feature consisted of a semicircular concentration of burned tabular limestone cobbles measuring roughly $80 \times 54 \mathrm{~cm}$. No cultural materials were observed during the excavation of Feature 2. Flotation of feature matrix from both features did not produce any charcoal or identifiable organic materials.

The distributions of the cultural materials and features suggest that the deposits associated with $41 \mathrm{HM} 53$ are no more than ca. $40 \mathrm{~cm}$ thick. No charcoal or other organic materials for dating were recovered. All three of the projectile points recorded at the site are similar to Provisional Type 1 points from Fort Hood, suggesting that the site may date to the Early to Middle Archaic period, but the lack of accompanying radiocarbon dates makes it impossible to confirm this.

Investigation of 41HM53 yielded only small amounts of cultural materials and two features. Though the part of 41HM53 inside the U.S. Highway 281 right of way appears to represent a reasonably discrete prehistoric occupation buried in late Holocene alluvium, cultural materials are so sparse that it is doubtful that interpretable samples of artifacts and other materials-including charcoal suitable for dating - could be recovered. The site does not appear have the capacity to contribute important information for understanding the prehistory of the area, and hence it was recommended that 41HM53 be judged ineligible for listing in the National Register of Historic Places under Criterion D (36 CFR 60.4) and designation as a State Archeological Landmark (Chapter 26.8, Rules of Practice and Procedure for the Antiquities Code of Texas).

\section{LT307, Work Authorization 30}

Prehistoric site 41LT307 was recorded on private land in the proposed new right of way during a survey for a bridge replacement on CR 153 at the Navasota River in northern Limestone County. Seven Gradall trenches and two shovel tests were excavated in addition to inspection of deep subsurface deposits in cut banks of the river channel and several erosional gullies. Trenches 1 and 2 were placed outside the existing right of way in the southwest quadrant of the project area and Trenches 3 and 7 were placed in proposed new right of way in the southeast and northwest quadrants, all with negative results. 
Trenches 4-6 and Shovel Tests 1 and 2 were placed in the northeast quadrant, with Trench 4 and Shovel Test 2 being in the proposed new right of way and the other trenches and shovel test being beyond the new right of way to the east. Visual inspection of this quadrant revealed two short erosional gullies in the new right of way and the area just to the east extending from the cut banks of the river northward ca. $5 \mathrm{~m}$. Several burned rock fragments and pieces of chert debitage were encountered eroding from the cut banks ca. $70-100 \mathrm{~cm}$ below the original ground surface. Further inspection revealed a Darl projectile point eroding out of the gully cut bank ca. $73 \mathrm{~cm}$ below the ground surface. Additional cultural materials were found in Trenches 4 and 5 and both shovel tests in this area. The cultural materials were recorded as 41LT307. Trench 4 at the east edge of the new right of way and Trench 5 ca. $13 \mathrm{~m}$ farther east revealed similar stratigraphic profiles, although Trench 4 was in an area where the upper ca. $40 \mathrm{~cm}$ of the floodplain deposits had been removed by erosion. The upper $20 \mathrm{~cm}$ consisted of a sandy silty loam (10YR 4/2) that appeared not to contain cultural materials. Zone 2 between 20 and 90-105 cm consisted of a silty clay loam (5YR 3/4 to 10YR 3/4) and contained a few burned rocks and pieces of chert debitage concentrated between 60 and $100 \mathrm{~cm}$. Dense clay was located below Zone 2 down to $225 \mathrm{~cm}$. No cultural materials were encountered in the clay deposit.

Shovel Tests 1 and 2 were placed on the walls of Trenches 5 and 4, respectively, to better document the artifact densities and distributions. Shovel Test 1 was dug to $120 \mathrm{~cm}$ and contained one chert flake between 60 and $80 \mathrm{~cm}$. Shovel Test 2 also was dug to $120 \mathrm{~cm}$. The upper $20 \mathrm{~cm}$ (ca. 40-60 cm below the original surface) contained six burned rocks and three pieces of chert debitage. Next, between 20 and $40 \mathrm{~cm}(60-80 \mathrm{~cm}$ below the original surface), only two burned rocks were encountered. No other cultural materials were found in this shovel test.

Trench 6 was placed ca. $10 \mathrm{~m}$ north of Trenches 4 and 5 , outside the proposed new right of way. No cultural materials were encountered in Trench 6. Apparently, 41LT307 does not extend this far north. Based on the information from Trenches 4 and 5, 41LT307 appears to be a light accumulation of cultural materials between 40 and $100 \mathrm{~cm}$ beneath the original ground surface. Its full dimensions are not known, since it most certainly extends eastward beyond Trench 5 . Within the current project area, however, it probably extends ca. $10 \mathrm{~m}$ west from Trench 4 back to CR 153 and no more than $20 \mathrm{~m}$ north from the river bank. The lack of artifacts in Trench 7 suggests that it does not extend west of CR 153. Based on the recovery of the single Darl point, it dates at least partly to the Late Archaic period, which is consistent with its shallow burial in late Holocene alluvium. The concentration of cultural materials between 40 and $100 \mathrm{~cm}$ suggests that the site may contain undisturbed deposits. If so, it may contain important information about Native American use of the Navasota River floodplain and hence be eligible for listing in the National Register of Historic Places under Criterion D (36 CFR 60.4) and designation as a State Archeological Landmark (Chapter 26.8, Rules of Practice and Procedure for the Antiquities Code of Texas). Archeological testing to determine this was recommended.

\section{SV4 and 41SV51, Work Authorization 8}

Two previously recorded prehistoric sites (41SV4 and 41SV51) were investigated during a survey of a bridge replacement on U.S. Highway 67 at Squaw Creek in eastern Somervell County. The work was conducted in two phases. Phase 1 of the survey consisted of visual inspection accompanied by the excavation of 12 backhoe trenches on state-owned land inside the existing right of way. The trench profiles revealed Holocene alluvium consisting of a thick, dense clay exhibiting little pedogenesis. Typically, the soil profiles consisted of a 30-40-cm-thick dark brown sandy silty clay and an underlying 150 250 -cm-thick dense brown clay. Cultural materials were encountered in four trenches on the west side of Squaw Creek. Trench 3 contained two chert flakes ca. $30 \mathrm{~cm}$ below the surface, and Trenches 5 and 6 each contained only a few pieces of lithic debitage above $40 \mathrm{~cm}$. Most of the cultural materials were encountered in Trench 4 in the northwest quadrant of the project area and consisted of sparse debitage, one Axtell projectile point, and scattered burned rocks. These materials were present between 30 and $76 \mathrm{~cm}$ below the ground surface. In addition, four possible features were encountered in the walls and floor of Trench 4. Based on these findings, it was concluded that potentially 
intact deposits associated with previously recorded site 41SV4 just north of the existing right of way could extend into the current project area, with the area of Trench 4 having the greatest potential for such deposits. The sparser cultural materials in Trenches 3,5 , and 6 appeared to represent parts of 41SV4 that were too disturbed to contribute important information. Hence, more-intensive survey focusing on the immediate vicinity of Trench 4 was recommended.

Limited cultural materials were encountered (but not collected) in trenching the existing right of way east of Squaw Creek. These consisted of a few burned rocks found between 160 and $180 \mathrm{~cm}$ in Trench 7 in the northeast quadrant and two burned rocks found at $89 \mathrm{~cm}$ in Trench 10 in the southeast quadrant. These materials could be associated with 41SV51 recorded to the north and northeast beyond the existing right of way, or they could have been washed in from 41SV4, 41SV51, or other sites upstream by flooding of Squaw Creek. The cultural materials in the trenches east of Squaw Creek were considered to be too sparse to contribute important information and thus were judged to be ineligible for listing in the National Register of Historic Places or designation as a State Archeological Landmark, and further work was not warranted there.

The second phase of the survey consisted of reopening Trench 4, excavating a ca. 5-m-long new trench a few meters southwest of Trench 4 , and manually excavating seven $1 \times 1-m$ test units, all on state-owned land within the existing right of way. Test Units 1 and 2 were placed within and beneath Trench 4 to investigate Feature 6 found there during the initial survey work, and Test Units 3-5 were placed next to the walls of Trench 4 . Test Units 6 and 7 adjoined the new trench. About $30 \mathrm{~cm}$ of sterile overburden was removed from the test units so that manual excavation could focus on the cultural zone identified at $30-76 \mathrm{~cm}$ in Trench 4 . Placement of all units was predicated on locating possible cultural features in the walls or floors of the trenches. The volume of sediment removed from the seven test units totaled $4.35 \mathrm{~m}^{3}$. Because the sediments were clayey, water screening was implemented. The matrix of four of the six features encountered was collected in bulk for flotation. Flotation was initiated in an effort to locate charcoal and other organic materials in addition to small cultural materials associated with features. Flotation produced only a small amount of cultural material and sparse unidentifiable organic material but no charcoal, however, and thus the light fractions were not submitted for analysis. Excavation of each test unit was terminated just below the base of the features encountered or at levels where cultural material recovery was extremely low.

The prehistoric cultural materials recovered during survey at 41SV4 consist of 1 Axtell projectile point found during the initial trenching; 525 pieces of lithic debitage, 7 edge-modified flakes, 1 tested cobble, 1 ground stone, 1 hammerstone, 5 pieces of bone, and $24.8 \mathrm{~kg}$ of burned rocks found in screening the sediments from the test units; and 48 pieces of debitage, 8 bone fragments, and 1,459.2 $\mathrm{g}$ of burned rocks from the heavy fractions of matrix collected from features for flotation. The bulk of the debitage consists of secondary and tertiary flakes with a few small primary flakes present. The seven edge-modified flakes consist of secondary flakes containing small amounts of retouch on one side. The tested cobble is a small chert cobble with three flake scars on one side. The ground stone consists of a fractured fragment with evidence of grinding on one side. All bone fragments recovered are small and unidentifiable.

Six features were exposed and excavated. Features 1-5 were small burned rock accumulations, possibly disarticulated hearths. Feature 6 consisted of a $130 \times 100-\mathrm{cm}$ rock-lined basin hearth. Over 75 mostly tabular to subangular burned rocks were removed from the feature as well as 10 fragments of unidentifiable bone, 6 pieces of debitage, and 1 hammerstone. Two charcoal samples were collected from beneath burned rocks in the feature and yielded uncorrected ages of $4340 \pm 70$ B.P. (UGA-14035; corrected age $=4350 \pm 70$ B.P.; calibrated two-sigma date range $=3350-2750$ B.C.) and $3470 \pm 60$ B.P. (UGA-14036; corrected age $=3560 \pm 60$ B.P.; calibrated two-sigma date range $=2120-2090 / 2040$ 1730 B.C.). The calibrated date range of the second sample indicates that some of the activity associated with the feature took place during the Middle Archaic period, and this is consistent with the presumed age of the Axtell point found with Feature 6 during the first phase of survey. The earlier date of the first sample suggests that the feature or portions of the site also were used during the late part of the Early Archaic period, possibly hinting at a 
long period of activity at the site.

Based on the distributions of the artifacts and features, two possible zones of occupation were defined, one between 99.27 and $98.90 \mathrm{~m}$ in elevation and one between 98.80 and $98.50 \mathrm{~m}$. The upper zone contains the highest artifact densities. Features are also more abundant in the upper zone, however, they appear small and disturbed. Features $1-5$ were all associated with this zone. No charcoal or other organic materials for dating and no temporally diagnostic artifacts were recovered, but the dates associated with the lower zone suggest that this upper zone postdates the middle part of the Middle Archaic period. The lower, apparently more-intact zone contained only one feature (Feature 6) and had moderate artifact densities. The two radiocarbon dates from Feature 6 indicate that this zone dates to the latter part of the Early Archaic period and the early part of the Middle Archaic period.

Survey investigations for the bridge replacement on U.S. Highway 67 at Squaw Creek resulted in locating and sampling an intact portion of 41SV4 in the northwest quadrant within the existing right of way. Trenching in the remaining three quadrants exposed limited cultural materials that appear to represent disturbed parts of 41SV4 and 41SV51, or, in the case of the areas east of the creek, materials redeposited from other nearby sites by creek flooding; the sparse archeological deposits in these three quadrants are not capable of contributing important information and thus are ineligible for National Register (36 CFR 60.4) or State Archeological Landmark (Chapter 26.8, Rules of Practice and Procedure for the Antiquities Code of Texas) listing. The part of 41SV4 in the northwest quadrant of the project area appears to have two superimposed occupation zones buried shallowly in middle to late Holocene alluvium. The upper zone has numerous artifacts and cultural features, but the nature of the features suggests that these deposits are of low integrity. Further, the age or ages of the remains in this zone are unknown, as no diagnostic artifacts or datable materials were recovered. The lower zone appears to have a more-intact Early to Middle Archaic component containing at least one feature, moderate artifact densities, and datable materials. However, a substantial portion of this component located within the existing right of way was removed during these survey investigations, and it is doubtful that the little that remains would contribute additional important information. Hence, the part of the site within the existing right of way is considered ineligible for listing in the National Register of Historic Places under Criterion D (36 CFR 60.4) or designation as a State Archeological Landmark (Chapter 26.8, Rules of Practice and Procedure for the Antiquities Code of Texas). It is uncertain if intact portions of the site extend north of the current project area onto the golf course.

\section{SV153, Work Authorization 15}

Site 41SV153, a buried prehistoric site, was recorded during trenching for a bridge replacement on SH 144 at Squaw Creek in central Somervell County. Six backhoe trenches were placed on private land along the path of a proposed easement needed for a detour both north and south of the creek. Three trenches were excavated in the southern half of the project area. Due to the extensive disturbance both observed and reported along the lower terrace, all subsurface investigation focused on the upper terrace. No cultural materials were found south of the creek.

Three trenches were excavated in the northern half of the project area within 4 m east of the existing SH 144 right of way, and two of these contained cultural materials. Backhoe Trench 5 exposed a thick cap of dark brown silty sandy clay gradually transitioning around $50 \mathrm{~cm}$ to a lighter brown sandy clay with dense gravels and $\mathrm{CaCO}_{3}$ below $70 \mathrm{~cm}$. A discrete lens of burned rocks was exposed between 30 and $50 \mathrm{~cm}$ along the entire length of the trench. The lens was also present in the east wall between 50 and $80 \mathrm{~cm}$, though it became less dense along the southernmost extent of the profile. In both walls, the burned rock lens corresponded closely with the interface between the darker silty sandy clay loam and the lighter sandy gravelly clay, suggesting a possible occupational surface. The northern extent of the lens in the eastern profile extended downward at a sharp angle to near the floor of the trench at $100 \mathrm{~cm}$, implying that the trench may have truncated the edge of a basin or pit feature. Small amounts of charcoal and debitage, but no diagnostic artifacts, were observed in the burned rock lens. 
Backhoe Trench 6 exposed a stratigraphy that compared closely with that of Backhoe Trench 5. A burned rock lens was found between 45 and $60 \mathrm{~cm}$ and was exposed intact across the southern half of the trench floor. Small amounts of debitage and charcoal were observed in this lens and in the trench backdirt.

The prehistoric site identified in Backhoe Trenches 5 and 6 is a buried component of unknown age that could cover all of the proposed temporary easement from Backhoe Trench 6 northward and that probably extends eastward beyond the current project area. Given its setting within Holocene alluvium, 41SV153 was considered to have the potential for discrete occupations, but it could not be fully evaluated based on the data produced at this level of investigation. Thus, test excavations were recommended to determine if the site is eligible for designation as a State Archeological Landmark (Chapter 26.8, Rules of Practice and Procedure for the Antiquities Code of Texas) and listing in the National Register of Historic Places under Criterion D (36 CFR 60.4).

\section{SV157, Work Authorization 21}

A newly recorded buried prehistoric site (41SV157) was recorded in the new and existing rights of way during survey for a bridge replacement on U.S. Highway 67 at the Paluxy River in northern Somervell County. Survey consisted of the excavation of nine backhoe trenches and nine shovel tests. Of these, three trenches and three shovel tests exposed cultural material. Work took place in two phases. The initial phase consisted of the impact evaluation, excavation of Trenches 1-6 and Shovel Tests 1-7, and initial documentation of 41SV157. The discovery of 41SV157 in the existing right of way necessitated a second phase of survey to look at the new right of way in this area. Trenches 7-9 and Shovel Tests 8 and 9 were excavated during the second phase.

Trenches 6-8 and Shovel Tests 8 and 9 contained cultural materials and exposed similar stratigraphic profiles and sediments. Zone 1 ranged between 35 and $45 \mathrm{~cm}$ thick and consisted of a sandy silty clay topsoil. This zone contained a few fragments of burned rock. Zone 2 was located between 35 and $270 \mathrm{~cm}$ and consisted of a sandy very silty clay alluvium with sparsely scattered burned rocks and a few pieces of debitage and mussel shells. The cultural materials were scattered throughout the deposits and did not occur in concentrations or lenses. Shovel Tests 8 and 9 were placed on the walls of Trenches 7 and 8 to better document artifact densities and distributions. Shovel Test 8 was dug to $160 \mathrm{~cm}$ and contained 2 flakes at 40 $60 \mathrm{~cm}, 1$ flake and 3 burned rocks at $80-100 \mathrm{~cm}$, 2 flakes and 5 burned rocks at 100-120 cm, 6 small burned rocks at 120-140 cm, and 7 mussel shell fragments at $140-160 \mathrm{~cm}$. Shovel Test 9 was dug to $140 \mathrm{~cm}$ and contained 1 burned rock and 1 mussel shell at $20-40 \mathrm{~cm}, 1$ burned rock at $40-60 \mathrm{~cm}, 1$ burned rock at $60-80 \mathrm{~cm}, 3$ burned rocks at $80-100 \mathrm{~cm}, 1$ flake and 10 burned rocks at $100-120 \mathrm{~cm}$, and 2 flakes and 8 burned rocks at $120-140 \mathrm{~cm}$. No evidence of cultural features was noted in any of the trenches or shovel tests, and no charcoal or organic materials other than mussel shell fragments were found.

The site consists of a series of floodplain occupations represented by sparse cultural materials that have been disturbed by high-energy flooding associated with the Paluxy River. Its full dimensions were not established, but the site almost certainly extends westward beyond the boundaries of the project area and measures at least $25 \mathrm{~m}$ east-west. The site measures ca. $40 \mathrm{~m}$ north-south and is restricted to a higher relict terrace, which is bounded on the north by a lower alluvial surface. The area south of Trenches 6-8 is covered with a large pile of recently introduced fill that occupies a low, probably truncated part of the terrace. The cultural deposits associated with $41 \mathrm{SV} 157$ are at least $200 \mathrm{~cm}$ thick based on the scattered materials observed throughout the trench walls.

The site consists of sparse burned rocks of various sizes and a few flakes and mussel shell fragment scattered throughout the trenches and shovel tests. The cultural materials do not occur in concentrations or lenses that indicate that discrete components could be isolated. No diagnostic artifacts, cultural features, or charcoal or other datable materials were encountered. These characteristics suggest that the cultural deposits have been disturbed by high-energy flooding of the Paluxy River and that the site has no capacity to contribute important information. Hence, it appears to be ineligible for listing in the National Register of Historic Places under 
Criterion D (36 CFR 60.4) or designation as a State Archeological Landmark (Chapter 26.8, Rules of Practice and Procedure for the Antiquities Code of Texas). No further archeological work was recommended within the current boundaries of 41SV157.

\section{Patterns in Site Distributions}

The 10 archeological sites observed occupy a variety of topographic settings. The two historic-age sites are in upland settings, with one house site (41FA85) on fluviatile terrace deposits in Falls County and one historic scatter associated with a probable farmstead (41ER44) on Cretaceous uplands in Erath County.

All eight prehistoric sites are in Holocene alluvium close to water sources. These sites are spread across two of the four districts included in this project (Fort Worth and Waco). Four of the eight sites are in the Fort Worth District in Somervell County: 41SV153, 41SV4, and 41SV51 on Squaw Creek, and 41SV157 on the Paluxy River. The remaining four sites are in the Waco district: 41BQ285 on the Bosque River in Bosque County, 41CV1636 on Cowhouse Creek in Coryell County, 41HM53 on the North Bosque River in Hamilton County, and 41LT307 on the Navasota River in Limestone County.

\section{UTILITY OF EXISTING METHODS}

The methods employed for Impact Evaluations and Surveys appear to be consistent with a reasonable and good-faith effort to comply with federal and state laws governing identification of archeological sites that are eligible for listing in the National Register of Historic Places or designation as State Archeological Landmarks. The level of effort typically required to complete an Impact Evaluation (e.g., 1-2 hours for a single bridge replacement) seems appropriate given the intent of this type of work and the generally small project areas. When Impact Evaluations can quickly separate those project areas for which survey is truly a good idea from those in which sites are very unlikely or almost surely disturbed, they are an efficient and relatively inexpensive measure to guard against the loss of important archeological data.

The levels of effort spent on Surveys and the amounts of work done (i.e., numbers of trenches and shovel tests) also seem appropriate given the sizes of the project areas, although the amount of work can vary based on factors other than project size (e.g., backhoe accessibility, depth to ground water, landowner permission to trench, extent of disturbance, and number and location of buried utilities that must be avoided during trenching). The work done on these surveys easily meets or exceeds the Texas Historical Commission's archeological survey standards, except in some cases in which only trenches were dug. This was the case in some floodplain settings where shovel testing was considered ineffective and inefficient because of the thickness of the alluvium or because of dense clay soils. In these cases, the much greater subsurface visibility afforded by the backhoe trenches and the fact that the number of trenches well exceeds the minimum required compensates for the lack of shovel testing.

\section{EVALUATION OF THE NEED FOR SURVEY}

This final section deals with the related topics of identifying patterns of existing conditions that affect the need for survey and predicting when field inspections are and are not needed. Based on the work done during this project, these issues can be addressed by looking at how often survey was deemed warranted when an Impact Evaluation was completed and the factors that contributed to these evaluations, as well as how often potentially significant archeological sites were found during surveys.

Of the 25 Impact Evaluations done, 8 led to recommendations that survey could be needed before construction. In 4 cases, the need for survey depended on whether new right of way would be acquired, which was unknown when the Impact Evaluations were done. The other 4 projects involved the acquisition of substantial amounts of new right of way, with the amount varying from 28 to 202 acres. These 4 projects spanned long stretches of highway (ranging from $11.1-25.0 \mathrm{~km}$ ) crossing numerous drainages (ranging from 7 to 42 crossings). On each of those 4 projects, at least one and up to four of the drainages had substantial Holocene alluvium.

The other 17 Impact Evaluations resulted in recommendations that no survey be required before construction based on the limited potential for sites with good integrity. Survey was not 
warranted for the following reasons. Nine of these Transportation Activities will require no new rights of way or easements, with all construction-related disturbances restricted to existing, already-disturbed rights of way. In the other 8 cases, Holocene deposits are thin or absent, and archeological deposits would be minimal if present. Many areas of new right of way also have been disturbed substantially.

The results of this project are consistent with the traditional thought that Transportation Activities that do not involve new right of way, particularly when they are in uplands or areas with thin Holocene deposits, are likely to be poor candidates for productive archeological survey. Beyond this, the frequent inability to predetermine where significant existing disturbances and thin (or no) alluvium might exist in project areas suggests that Impact Evaluations will continue to be the prudent choice on certain kinds of Transportation Activities, particularly those where significant accumulations of Holocene sediments could be present and those that are in settings (e.g., valley margins or proximity to known sites) where sites are likely, whether new right of way is involved or not.

Of the 52 Surveys done under this contract, 9 investigated 6 newly recorded and 4 previously recorded sites; 8 of the sites are prehistoric, and 2 are of historic age. This rate of positive surveys (17 percent) is lower than the results of three of the previous Survey and Impact Evaluation projects done for TxDOT by Prewitt and Associates (25 percent in the Abilene, Austin, Brownwood, Bryan, Fort Worth, Waco, and Yoakum Districts; 42 percent in the Atlanta, Dallas, Fort Worth, Paris, and Waco Districts; and 45 percent in the Austin and Waco Districts) and just barely higher than the other (16 percent in the Bryan, Corpus Christi, San Antonio, and Yoakum Districts). The reason for the lower rate of positive surveys in the current project is not apparent, although it does not appear to relate to a decrease in effort expended on surveys. For example, 295 trenches and 70 shovel tests and test pits were dug during the 52 surveys reported here, for an average of 5.7 trenches and 1.3 shovel tests and test pits per survey. This compares favorably to 4.5 trenches and 3.4 shovel tests per survey in the Abilene, Austin, Brownwood, Bryan, Fort Worth, Waco, and Yoakum Districts; 5.9 trenches and 1.7 shovel tests per survey in the Austin and Waco Districts;
3.9 trenches and 4.2 shovel tests per survey in the Bryan, Corpus Christi, San Antonio, and Yoakum Districts; and 6.0 trenches and 5.4 shovel tests per survey in the Atlanta, Dallas, Fort Worth, Paris, and Waco Districts. In any case, the rate of positive surveys in the current project is sufficient to suggest that conducting surveys in these areas generally was a good idea.

Of the 10 sites investigated during surveys, 4 prehistoric sites were recommended for testing to assess eligibility for listing in the National Register of Historic Places and designation as State Archeological Landmarks, and 1 historic site was recommended for archival and oral history research. Site 41BQ285 was judged to have the potential for important information because it contains a dense accumulation of undisturbed cultural materials between 28 and $60 \mathrm{~cm}$ and a sparser scatter between 60 and $80 \mathrm{~cm}$ in late Holocene alluvium. The presence of charcoal indicates that the deposits are datable. Site 41CV1636 was considered potentially significant because it is buried in Holocene alluvium and has abundant cultural materials that may be isolable into discrete components. Site 41LT307 was considered to have the potential to contain important information because it is buried in Holocene alluvium, and the concentration of cultural materials between 40 and $100 \mathrm{~cm}$ suggests that the site may contain undisturbed deposits. Site 41SV153 was judged potentially significant because it has dense cultural deposits buried between 45 and $80 \mathrm{~cm}$ in Holocene alluvium. Finally, historic site 41FA85 appears to date mostly to the first half of the twentieth century, but initial construction in the late nineteenth century is possible. Given its potentially early date and the presence of artifacts and features, it was recommended that information regarding the history and associations of the site needs to be gathered to aid in assessing it. Archival research involving deed, tax, and census records was recommended, along with oral history research.

Of the five sites (or parts of sites) investigated during surveys and not considered to warrant further work, four prehistoric sites (41HM53, 41SV4, 41SV51, and 41SV157) contain cultural materials buried within Holocene alluvium. Although the contexts of these sites are conducive to the preservation of important information, the archeological remains tend to be so sparse that it is doubtful that interpret- 
able samples representing isolable components could be recovered. Furthermore, some have been disturbed. One site (41ER44) is a historicage artifact scatter that extends into the new right of way and is too disturbed or too recent to yield important information.

In total, 50 percent of the sites investigated during surveys (50 percent of the prehistoric sites) were considered to have the potential to contain important information. Four of the five potentially important sites (41BQ285, 41CV1636, 41LT307, and 41SV153) later were subjected to test excavations by Prewitt and Associates under a separate contract. None of these were found to be eligible for listing in the National Register and designation as State Archeological Landmarks. It can be argued that the percentages mentioned in this paragraph should be higher, if the point is to maximize the effectiveness of the dollars spent on surveys. That is, shouldn't we be finding higher percentages of significant sites? The answer to this question is not so simple, however. There are many variables that contribute to decisions about when surveys are needed, and all sites encountered during surveys must be recorded, regardless of their apparent significance. There is even a competing argument that the percentages should go down as we get better at discriminating sites that are truly important from ones that are not. Ultimately, simple expectations such as these probably will never, or seldom, be met because the need to make sure that public monies are used effectively must be balanced against the need to ensure that important cultural resources are not lost without receiving the proper treatment.

\section{AVENUES OF FUTURE RESEARCH}

In a broad sense, the eight prehistoric sites investigated during this project offer information on the kinds of sites created by Native Americans in streamside and low terrace settings in the northern part of central Texas (Bosque, Coryell, Hamilton, and Somervell Counties) and the central Blackland Prairie (Limestone County). These range from very lowdensity artifact scatters such as 41LT307 and 41SV157, which probably represent lightly occupied extractive or processing localities, to sites such as 41BQ285 and 41CV1636 where abundant cultural materials represent longer occupations or more-frequent reoccupation of selected locales, probably for a broad range of activities. Additional work at the four sites recommended for testing (41BQ285, 41CV1636, 41LT307, and 41SV153) could provide a variety of kinds of information that would help clarify what Native Americans did at these locations, when they did it, and how these sites fit into larger settlement systems. These are the primary avenues of future research that these sites offer.

In terms of the historic sites, potential avenues of future research are limited by the small number of sites $(n=2)$ and the fact that one of them (41ER44) has no intact deposits inside the current project area and has a poorly understood history. Recommended research pertaining to the other site, 41FA85, is likely to yield information about agriculture and rural land use in the Fall County area during the late nineteenth and early to mid twentieth centuries. 



\section{REFERENCES CITED}

Antevs, Ernst

1948 The Great Basin, with Emphasis on Glacial and Postglacial Times. University of Utah Bulletin 38:168-191. Salt Lake City.

1955 Geologic-Climatic Dating in the West. American Antiquity 20:317-335.

Barber, Byron L.

1969 The Hackberry Site. The Record 25(3):1824.

Barnes, V. E., and P. R. Rose

1981 Geologic Atlas of Texas, Llano Sheet. Bureau of Economic Geology, The University of Texas at Austin.

Black, Stephen L.

1989 Central Texas Plateau Prairie. In From the Gulf to the Rio Grande: Human Adaptation in Central, South, and Lower Pecos, Texas, by Thomas R. Hester, Stephen L. Black, D. Gentry Steele, Ben W. Olive, Anne A. Fox, Karl J. Reinhard, and Leland C. Bement, pp. 17-38. Research Series No. 33. Arkansas Archeological Survey, Fayetteville.

Black, Stephen L., Linda W. Ellis, Darrell G. Creel, and Glenn T. Goode

1997 Hot Rock Cooking on the Greater Edwards Plateau: Four Burned Rock Midden Sites in West Central Texas. 2 vols. Studies in Archeology 22. Texas Archeological Research Laboratory, The University of Texas at Austin. Archeology Studies Program Report 2. Environmental Affairs Department, Texas Department of Transportation, Austin.

Black, Stephen L., and A. Joachim McGraw 1985 The Panther Springs Creek Site: Cultural Change and Continuity within the Upper
Salado Creek Watershed, South-Central Texas. Archeological Survey Report No. 100. Center for Archaeological Research, The University of Texas at San Antonio.

Blum, Michael D., and Salvatore Valastro Jr.

1989 Response of the Pedernales River of Central Texas to Late Holocene Climatic Change. Annals of the Association of American Geographers 79(3):435-456.

Bond, Clell L.

1978 Three Archeological Sites at Hoxie Bridge, Williamson County, Texas. Report No. 43. Anthropology Laboratory, Texas A\&M University, College Station.

Bousman, C. Britt

1992 Preliminary Oxygen Isotope Evidence for Late Pleistocene-Early Holocene Climatic Change. Current Research in the Pleistocene 9:78-79.

1994 The Central Texas Pollen Record: A Reinterpretation. Current Research in the Pleistocene 11:79-81.

1998 Paleoenvironmental Change in Central Texas: The Palynological Evidence. Plains Anthropologist 43(164):201-219.

Bousman, C. Britt, Steve A. Tomka, and Gail L. Bailey 1990 Prehistoric Archeology and Paleoenvironments in Hidalgo and Willacy Counties, South Texas: Results of the Phase II Texas Excavations. Reports of Investigations No. 76. Prewitt and Associates, Inc., Austin.

Boyd, Douglas K.

1995 The Palo Duro Complex: Redefining the Early Ceramic Period in the Caprock Canyonlands. Bulletin of the Texas Archeological Society 66:461-518. 
1997 Caprock Canyonlands Archeology: A Synthesis of the Late Prehistory and History of Lake Henry and The Texas PanhandlePlains. 2 vols. Reports of Investigations No. 110. Prewitt and Associates, Inc., Austin.

2001 Querechos and Teyas: Protohistoric Hunters and Gatherers in the Texas PanhandlePlains, A.D. 1540-1700. Bulletin of the Texas Archeological Society 72:5-22.

Boyd, Douglas K., Martha Doty Freeman, Michael D. Blum, Elton R. Prewitt, and J. Michael Quigg

1989 Phase I Cultural Resources Investigations at Justiceburg Reservoir on the Double Mountain Fork of the Brazos River, Garza and Kent Counties, Texas. 2 vols. Reports of Investigations No. 66. Prewitt and Associates, Inc., Austin.

Brayshaw, Thomas C.

1970 Henrietta Focus of the Possum Kingdom Basin. Master's thesis, Department of Anthropology, The University of Texas at Austin.

Broecker, W. S., J. P. Kennett, B. P. Flower, J. T. Teller, S. Trumbore, G. Bonani, and W. Wolfi

1998 Routing of Meltwater from the Laurentide Ice Sheet During the Younger Dryas Cold Episode. Nature 341:381-321.

Brooks, Robert L.

1989 Village Farming Societies. In From Clovis to Comanchero: Archeological Overview of the Southern Great Plains, by Jack L. Hoffman, Robert L. Brooks, Joe S. Hays, Douglas W. Owsley, Richard L. Jantz, Murray K. Marks, and Mary H. Manhein, pp. 71-90. Research Series No. 35. Arkansas Archeological Survey, Fayetteville.

1994 Warfare on the Southern Plains. In Skeletal Biology in the Great Plains: Migration, Warfare, Health, and Subsistence, edited by Douglas W. Owsley and Richard L. Jantz, pp. 317-323. Smithsonian Institution Press, Washington, D.C.

Brown, David O. (compiler)

1987 Archeology at Aquilla Lake, 1978-1982 Investigations. Research Report 81. Texas Archeological Survey, The University of Texas at Austin.

Brown, David O., and Dana Anthony
1992 Archeological Survey of the Proposed Salt Creek II Substation and Electric Transmission Line, Kent County, Texas. Summary Report 10. Hicks and Company, Inc., Austin.

Brown, K. L., and S. A. Lebo

1991 Archaeological Testing of the Lewisville Lake Shoreline, Denton County, Texas. Institute of Applied Sciences, University of North Texas, Denton.

Brown, L. F., Jr., J. L. Goodson, and P. Harwood

1972 Geologic Atlas of Texas, Abilene Sheet. Bureau of Economic Geology, The University of Texas at Austin.

Brown, Theodore M., Kay L. Killen, Helen Simons, and Virginia Wulfkuhle

1982 Resource Protection Planning Process for Texas. Texas Historical Commission, Austin.

Brownlow, Russ

2003 Archeological Investigations at 41WM815, A Blackland Prairie Site, Williamson County, Texas. Studies in Archeology 36. Texas Archeological Research Laboratory, The University of Texas at Austin. Archeological Studies Program Report 23. Environmental Affairs Division, Texas Department of Transportation, Austin.

Bruseth, James E., and William A. Martin (editors)

1987 The Bird Point Island and Adams Ranch Sites: Methodological and Theoretical Contributions to North Central Texas Archaeology. Richland Creek Technical Series, Vol. II. Archaeology Research Program, Institute for the Study of Earth and Man, Southern Methodist University, Dallas.

Bryant, Vaughn M., Jr., and Richard G. Holloway

1985 A Late Quaternary Paleoenvironmental Record of Texas: An Overview of Pollen Evidence. In Pollen Records of Late-Quaternary North American Sediments, edited by Vaughn M. Bryant Jr. and Richard G. Holloway, pp. 39-70. American Association of Stratigraphic Palynologists Foundation, Dallas.

Bryant, Vaughn M., Jr., and Donald A. Larson

1968 Pollen Analysis of the Devil's Mouth Site, Val Verde County, Texas. Appendix in The Devil's Mouth Site: The Third Season1967, by William M. Sorrow, pp. 57-70. Papers of the Texas Archeological Salvage 
Project, No. 14. Texas Archeological Salvage Project, The University of Texas at Austin.

Bryant, Vaughn M., Jr., and Harry J. Shafer

1977 The Late Quaternary Paleoenvironment of Texas: A Model for the Archeologist. Bulletin of the Texas Archeological Society 48:1-25.

Campbell, Thomas N.

1983 Espinosa, Olivares, and the Colorado River Indians, 1709. Sayersville Historical Association Bulletin 3:2-16.

1988 Indians of Southern Texas and Northeastern Mexico: Selected Writings of Thomas Nolan Campbell. Texas Archeological Research Laboratory, with the cooperation of the Department of Anthropology, the College of Liberal Arts, and the Institute of Latin American Studies, The University of Texas at Austin.

Cliff, Maynard B., Richard Martynec, Sharlene N. Allday, and Duane E. Peter

1991 Cultural Resources Sample of the Elm Creek Detention and Channelization Area, Abilene, Taylor County, Texas. Miscellaneous Report of Investigations No. 21. GeoMarine, Inc., Plano.

Collins, Michael B.

1968 A Note on Broad Corner-Notched Projectile Points Used in Bison Hunting in Western Texas. The Bull Roarer 3(2):13-14. The U. T. Anthropological Society, Department of Anthropology, The University of Texas at Austin.

1990 Observations on Clovis Lithic Technology. Current Research in the Pleistocene 7:7374 .

1995 Forty Years of Archeology in Central Texas. Bulletin of the Texas Archeological Society 66:361-400.

Collins, Michael B. (assembler and editor)

1998 Wilson-Leonard: An 11,000-year Archeological Record of Hunter-Gatherers in Central Texas. 5 vols. Studies in Archeology 31. Texas Archeological Research Laboratory, The University of Texas at Austin. Archeology Studies Program Report 10. Texas Department of Transportation, Environmental Affairs Division, Austin.
Collins, Michael B., and Kenneth M. Brown

2000 The Gault Gisement: Some Preliminary Observations. I 2(1):8-11.

Collins, Michael B., Glen L. Evans, Thomas N. Campbell, Melissa C. Winans, and Charles E. Mear

1989 Clovis Occupation at Kincaid Rockshelter, Texas. Current Research in the Pleistocene $6: 3-4$

Collins, Michael B., Thomas R. Hester, and Pamela J. Headrick

1992 Engraved Cobbles from the Gault Site, Central Texas. I 9:3-4.

Creel, Darrell

1986 A Study of Prehistoric Burned Rock Middens in West Central Texas. Ph.D. dissertation, Department of Anthropology, The University of Arizona, Tucson.

1990 Excavations at 41TG91, Tom Green County, Texas. Publications in Archaeology Report No. 38. Texas State Department of Highways and Public Transportation, Highway Design Division, Austin.

Crook, Wilson W., Jr., and R. K. Harris

1952 Trinity Aspect of the Archaic Horizon: The Carrollton and Elam Foci. Bulletin of the Texas Archeological and Paleontological Society 23:7-38.

1954 Traits of the Trinity Aspect Archaic: Carrollton and Elam Foci. The Record 12(1):2-16.

1957 Hearths and Artifacts of Early Man Near Lewisville, Texas, and Associated Faunal Material. Bulletin of the Texas Archeological Society 28:7-97.

1958 A Pleistocene Campsite Near Lewisville, Texas. American Antiquity 23(3):233-246.

Dawson, Gerald L., and Timothy L. Sullivan

1973 Excavations at Lake Lavon, 1969. Research Report No. 25. Archaeology Research Program, Southern Methodist University, Dallas.

Dering, Phil

1999 Earth-Oven Plant Processing in Archaic Period Economies: An Example from a Semi-arid Savannah in South-Central North America. American Antiquity 64(4):659-674. 
Denton, Joe T

1983 Test Excavations at Site 41KT32, Kent County, Texas. Texas Department of Highways and Public Transportation, Austin.

Diamond, David D., David H. Riskind, and Steve L. Orzell

1987 A Framework for Plant Communities Classification and Conservation in Texas. Texas Journal of Science 39(3):203-221.

Dibble, David S., and Dessamae Lorrain

1968 Bonfire Shelter:A Stratified Bison Kill Site, Val Verde County, Texas. Miscellaneous Papers No. 1. Texas Memorial Museum, The University of Texas at Austin.

Dillehay, Tom D.

1974 Late Quaternary Bison Population Changes on the Southern Plains. Plains Anthropologist 19(64):180-196.

Duffield, Lathel F.

1963 The Strawn Creek Site: A Mixed Archaic and Neo-American Site at Navarro Mills Reservoir, Navarro County, Texas. Report submitted to the National Park Service by the Texas Archeological Salvage Project, The University of Texas at Austin.

Eifler, G. K., Jr., J. C. Frye, and A. B. Leonard 1967 Geologic Atlas of Texas, Lubbock Sheet. Bureau of Economic Geology, The University of Texas at Austin.

1974 Geologic Atlas of Texas, Big Spring Sheet. Bureau of Economic Geology, The University of Texas at Austin.

Ensor, H. Blaine, Joe W. Saunders, and C. S. MuellerWille

1992 Prehistoric Synthesis. In An Archeological Survey of the Proposed South Bend Reservoir Area: Young, Stephens, and Throckmorton Counties, Texas, edited by Joe W. Saunders, C. S. Mueller-Wille, and David L. Carlson, pp. 259-303. Archeological Surveys No. 6. Archeological Research Laboratory, Texas A\&M University, College Station.

Etchieson, Gerald Meeks, Roberta D. Speer, and Jack T. Hughes

1979 Archeological Investigations in the Crowell Reservoir Area, King and Knox Counties, Texas. Archeological Research Laboratory, Killgore Research Center, West Texas State University, Canyon.
Fairbanks, R. G.

1989 A 17,000 Year Glacio-Eustatic Sea-Level Record: Influence of Glacial Melting Rates on the Younger Dryas Event and Deep Ocean Circulation. Nature 342:637-642.

Fenneman, Nevin M.

1931 Physiography of Western United States. McGraw-Hill Book Company, Inc., New York.

1938 Physiography of Eastern United States. McGraw-Hill Book Company, Inc., New York.

Ferring, C. Reid

1975 An Archeological Survey of the Grapevine Dam Area, Tarrant County, Texas. Archeology Research Program, Southern Methodist University, Dallas.

2001 The Archaeology and Paleoecology of the Aubrey Clovis Site (41DN479), Denton County, Texas. Center for Environmental Archaeology, Department of Geography, University of North Texas, Denton.

Ferring, C. Reid, and Bonnie C. Yates

1997 Holocene Geoarcheology and Prehistory of the Ray Roberts Lake Area. Institute of Applied Sciences, University of North Texas, Denton.

1998 Archaeological Investigations at Five Prehistoric Sites at Lewisville Lake, Denton County, Texas. Center for Environmental Archaeology, University of North Texas, Denton.

Forrester, R. E.

1987 The Moran Point from North-Central Texas. Bulletin of the Oklahoma Anthropological Society 36:131-136.

1994 Two Henrietta Focus Sites on the Brazos River in North Central Texas. Bulletin of the Texas Archeological Society 62:249266.

Foster, William C.

1995 Spanish Expeditions into Texas 16891768. University of Texas Press, Austin.

Frederick, Charles D.

1998 Late Quaternary Clay Dune Sedimentation on the Llano Estacado. Plains Anthropologist 43(164): 137-155. 
Frederick, Charles, D., and Christopher Ringstaff 1994 Lithic Resources at Fort Hood: Further Investigations. In Archeological Investigations on 571 Prehistoric Sites at Fort Hood, Bell and Coryell Counties, Texas, edited by W. Nicholas Trierweiler, pp. 125-181. Research Report No. 31. Archeological Resource Management Series, United States Army Fort Hood.

Gadus, Eloise F., Ross C. Fields, and Karl W. Kibler 2006 Data Recovery Excavations at the J. B. White Site (41MM341), Milam County, Texas. Reports of Investigations No. 145. Prewitt and Associates, Inc., Austin. Archeological Studies Program Report No. 87. Environmental Affairs Division, Texas Department of Transportation, Austin.

Gill-King, H.

1987 The Human Osteology of 41CO141. In Test Excavations at 41CO141, Ray Roberts Reservoir, Cooke County, Texas, edited by Daniel J. Prikryl and Bonnie C. Yates, pp. 101-104. Contributions in Archaeology No. 4. Institute of Applied Sciences, North Texas State University, Denton.

Gilmore, Kathleen Kirk

1996a San Francisco Xavier de Horcasitas Mission. In The New Handbook of Texas 5:849. The Texas State Historical Association, Austin.

1996b San Ildefonso Mission. In The New Handbook of Texas 5:853-854. The Texas State Historical Association, Austin.

Godwin, Molly F.

2004 A Report of an Archeological Survey in the M. McKinney Survey, Abstract 886, Erath County, Texas. Heritage Management Series Survey Report 1. Big Country Archeology, Desdemona, Texas.

Goode, Glenn T.

1991 Late Prehistoric Burned Rock Middens in Central Texas. In The Burned Rock Middens of Texas: An Archeological Symposium, edited by Thomas R. Hester, pp. 71-93. Studies in Archeology 13. Texas Archeological Research Laboratory, The University of Texas at Austin.

Goode, Glenn T., and Robert J. Mallouf

1991 The Evant Cores: Polyhedral Blade Cores from North-Central Texas. Current Research in the Pleistocene 8:67-70.
Green, F. E.

1963 The Clovis Blades: An Important Addition to the Llano Complex. American Antiquity 29(2):145-165.

Green, L. M., and Thomas R. Hester

1973 The Finis Frost Site: A Toyah Phase Occupation in San Saba County, Central Texas. Bulletin of the Texas Archeological Society 44:69-88.

Hall, Stephen A.

1982 Late Holocene Paleoecology of the Southern Plains. Quaternary Research 17:391407.

1988 Environment and Archaeology of the Central Osage Plains. Plains Anthropologist 33(110)277-291.

1990 Channel Trenching and Climatic Change in the Southern U.S. Great Plains. Geology 18:342-345.

Harris, R. K.

1945 Bone Implement Burial, Collin County, Texas. Bulletin of the Texas Archeological and Paleontological Society 16:84-89.

Harris, R. K., and Inus Marie Harris

1970 A Bison Kill on Dixon's Branch, Site 27A25, Dallas County, Texas. The Record 27(1):1-4.

Harris, R. K., and Dee Ann Suhm (editors)

1963 An Appraisal of the Archeological Resources of Forney Reservoir, Collin, Dallas, Kaufman, and Rockwall Counties, Texas. Texas Archeological Salvage Project, The University of Texas at Austin.

Harrison, Billy R., and Kay L. Killen

1978 Lake Theo: A Stratified Early Man Bison Butchering and Camp Site, Briscoe County, Texas: Archeological Investigations, Phase II. Special Archeological Report No. 1. Panhandle-Plains Historical Museum, West Texas State University, Canyon.

Hatfield, Virginia L.

1997 Paleoindian Evidence at the Triple S Ranch Site, Hamilton County, Texas. Current Research in the Pleistocene 14:32-34.

Hays, T. R. (compiler and editor)

1982 Archaeological Investigations at the San Gabriel Reservoir Districts, Central Texas. Archaeology Program, Institute of Applied 
Sciences, North Texas State University, Denton.

Hayward, O. T.

1988a The Comanchean Section of the Trinity Shelf, Central Texas. In South-Central Section of the Geological Society of America, Centennial Field Guide, Volume 4, edited by O. T. Hayward, pp. 323-328. Geological Society of America, Boulder, Colorado.

1988b Gulfian Rocks, Western Margin of the East Texas Basin. In South-Central Section of the Geological Society of America, Centennial Field Guide, Volume 4, edited by O.T. Hayward, pp. 329-334. Geological Society of America, Boulder, Colorado.

Hayward, O. T., Peter M. Allen, and David L. Amsbury 1996 Lampasas Cut Plain: Episodic Development of an Ancient and Complex Regional Landscape, Central Texas. In Guidebook to Upland, Lowland, and In BetweenLandscapes in the Lampasas Cut Plain, edited by David L. Carlson, pp. 1-1 through 1-97. Friends of the Pleistocene SouthCentral Cell 1996 Field Trip. Department of Anthropology, Texas A\&M University, College Station, and Department of Geology, Baylor University, Waco.

Hentz, T. F., and L. F. Brown Jr.

1987 Geologic Atlas of Texas, Wichita FallsLawton Sheet. Bureau of Economic Geology, The University of Texas at Austin.

Hickerson, Nancy P.

1994 The Jumanos, Hunters and Traders of the Southern Plains. University of Texas Press, Austin.

Hoffman, Jack L.

1989 Prehistoric Culture History-Hunters and Gatherers in the Southern Great Plains. In From Clovis to Comanchero: Archeological Overview of the Southern Great Plains, by Jack L. Hoffman, Robert L. Brooks, Joe S. Hays, Douglas W. Owsley, Richard L. Jantz, Murray K. Marks, and Mary H. Manhein, pp. 25-60. Research Series No. 35. Arkansas Archeological Survey, Fayetteville.

Hoffman, Jack L., Robert L. Brooks, Joe S. Hays, Douglas W. Owsley, Richard L. Jantz, Murray K. Marks, and Mary H. Manhein

1989 From Clovis to Comanchero:Archeological Overview of the Southern Great Plains. Re- search Series No. 35. Arkansas Archeological Survey, Fayetteville.

Holden, W. C.

1929 Some Recent Explorations and Excavations in Northwest Texas. Bulletin of the Texas Archeological and Paleontological Society 1:23-35.

Holliday, Vance T.

1997 Paleoindian Geoarchaeology of the Southern High Plains. University of Texas Press, Austin.

1989 Middle Holocene Drought on the Southern High Plains. Quaternary Research 31:74-82

Holloway, Richard G., and Vaughn M. Bryant Jr.

1984 Picea glauca Pollen from Late Glacial Deposits in Central Texas. Palynology 8:2132 .

Huebner, Jeffery A.

1991 Late Prehistoric Bison Populations in Central and South Texas. Plains Anthropologist 36(137):343-358.

Hughes, Jack T.

1942 An Archeological Excavation on the Harrell Site of North Central Texas. Master's thesis, Department of Anthropology, The University of Texas at Austin.

1991 Prehistoric Cultural Developments on the Texas High Plains. Bulletin of the Texas Archeological Society 60:1-55.

Jelks, Edward B.

1952 Appraisal of the Archeological and Paleontological Resources of the Colorado City Reservoir, Borden and Scurry Counties, Texas. River Basin Surveys, Smithsonian Institution, Washington, D.C.

1962 The Kyle Site: A Stratified Central Texas Aspect Site in Hill County, Texas. Archaeology Series No. 5. Department of Anthropology, The University of Texas at Austin.

1970 Documentary Evidence of Indian Occupation at the Stansbury Site. Bulletin of the Texas Archeological Society 41:277-286.

Johnson, Eileen (editor)

1977 Paleoindian Lifeways. The Museum Journal XVII. West Texas Museum Association, Texas Tech University, Lubbock. 
Johnson, LeRoy, Jr.

1991 Early Archaic Life at the Sleeper Archaeological Site, 41BC65, of the Texas Hill Country, Blanco County, Texas. Publications in Archaeology Report 39. Texas Department of Highways and Public Transportation, Highway Design Division, Austin.

1994 The Life and Times of Toyah-Culture Folk As Seen from the Buckhollow Encampment, Site 41KM16, of Kimble County, Texas. Report No. 38. Office of the State Archeologist, Texas Historical commission and Texas Department of Transportation, Austin.

1995 Past Cultures and Climates at Jonas Terrace: 41ME29 of Medina County, Texas. Report No. 40. Office of the State Archeologist, Texas Historical Commission, Austin.

2000 Life and Death as Seen at the Bessie Kruze Site (41WM13) on the Blackland Prairie of Williamson County, Texas. Archeology Studies Program Report 22. Environmental Affairs Division, Texas Department of Transportation, Austin.

Johnson, LeRoy, Jr., and Glenn T. Goode

1994 A New Try at Dating and Characterizing Holocene Climates, as Well as Archeological Periods, on the Eastern Edwards Plateau. Bulletin of the Texas Archeological Society 65:1-51.

Johnson, LeRoy, Jr., Dee Ann Suhm, and Curtis D. Tunnell

1962 Salvage Archeology of Canyon Reservoir: The Wunderlich, Footbridge, and Oblate Sites. Bulletin No. 5. Texas Memorial Museum, The University of Texas at Austin.

Katz, Paul, and Susana R. Katz

2002 Data Recovery at the Bear Branch Site (41CA13), Callahan County, Texas. PRIAM, Panhandle, Texas.

Kelley, J. Charles

1947a The Cultural Affiliations and Chronological Position of the Clear Fork Focus. American Antiquity 13(2):97-109.

1947b The Lehmann Rock Shelter: A Stratified Site of the Toyah, Uvalde, and Round Rock Foci. Bulletin of the Texas Archeological Society 18:115-128.
Kelley, J. C., and T. N. Campbell

1942 What are the Burnt Mounds of Texas? American Antiquity 7(3):319-322.

Kenmotsu, Nancy Adele

2001 Seeking Friends, Avoiding Enemies: the Jumano Response to Spanish Colonization, A.D. 1580-1750. Bulletin of the Texas Archeological Society 72:23-43.

Kerr, Anne C., and Susan W. Dial

1998 Statistical Analysis of Unfluted Lanceolate and Early Bifurcate Stem Projectile Points. In Wilson-Leonard:An 11,000year Archeological Record of Hunter-Gatherers in Central Texas, Volume II, edited and assembled by Michael B. Collins, pp. 447-505. Studies in Archeology 31. Texas Archeological Research Laboratory, The University of Texas at Austin. Archeology Studies Program Report 10. Environmental Affairs Division, Texas Department of Transportation, Austin.

Kibler, Karl W.

1998 Late Holocene Environmental Effects on Sandstone Rockshelter Formation and Sedimentation on the Southern Plains. Plains Anthropologist 43(164):173-186.

1999 Paluxy Geomorphic Investigations: Site Stratigraphy, Sediments, and Formation Processes. In National Register Testing of 42 Prehistoric Archeological Sites on Fort Hood, Texas: The 1996 Season, by Karl Kleinbach, Gemma Mehalchick, Douglas K. Boyd, and Karl W. Kibler, pp. 39-58. Archeological Resource Management Series, Research Report No. 38. United States Army, Fort Hood.

Kibler, Karl W., and Ann M. Scott

2000 Archaic Hunters and Gatherers of the Balcones Canyonlands: Data Recovery Excavations at the Cibolo Crossing Site (41BX377), Camp Bullis Military Reservation, Bexar County, Texas. Reports of Investigations No. 126. Prewitt and Associates, Inc., Austin.

Kier, R. S., L. F. Brown Jr., and P. Harwood

1976 Geologic Atlas of Texas, Brownwood Sheet. Bureau of Economic Geology, The University of Texas at Austin.

Kleinbach, Karl, Gemma Mehalchick, Douglas K. Boyd, and Karl W. Kibler

1999 National Register Testing of 42 Prehistoric 
Archeological Sites on Fort Hood, Texas: The 1996 Season. Research Report No. 38. Archeological Resource Management Series, United States Army Fort Hood.

Kleinbach, Karl, Gemma Mehalchick, James T. Abbott, and J. Michael Quigg

1995 Other Analyses. In NRHP Significance Testing of 57 Prehistoric Archeological Sites on Fort Hood, Texas, Volume II, edited by James T. Abbott and W. Nicholas Trierweiler, pp. 765-842. Research Report No. 34. Archeological Resource Management Series, United States Army Fort Hood.

Krieger, Alex D.

1946 Culture Complexes and Chronology in Northern Texas with Extension of Puebloan Dating to the Mississippi Valley. University of Texas Publication No. 4640. Austin.

Krieger, Margery $\mathrm{H}$.

1996 Tawakoni Indians. In The New Handbook of Texas 6:213. The Texas State Historical Association, Austin.

LBJ School of Public Affairs

1978 Preserving Texas' Natural Heritage. Project Report 31. Natural Heritage Policy Research Project, The University of Texas at Austin.

Leffler, John

1996a Brown County. In The New Handbook of Texas 1:769-771. The Texas State Historical Association, Austin.

1996b Eastland County. In The New Handbook of Texas 2:765-766. The Texas State Historical Association, Austin.

Lintz, Christopher, Abby C. Treece, Fred Oglesby, Karl Kibler, Patrick L. O’Neill, W. Nicholas Trierweiler, Charles Frederick, J. Michael Quigg, and A. J. Taylor

1993 Cultural Resource Investigations in the O.H. Ivie Reservoir, Concho, Coleman, and Runnels Counties, Texas, Volume II: Test Excavations at Prehistoric Sites and Assessment of Rock Cairn Features. Technical Report No. 346-II. Mariah Associates, Inc., Austin.

Lintz, Christopher, W. Nicholas Trierweiler, Fred Oglesby, Patrick O’Neill, William Doering, and Michael McFaul
1991 A Cultural Resource Survey at Mitchell Reservoir, Mitchell County, Texas. Technical Report 433. Mariah Associates, Inc., Austin.

Lorrain, Dessamae

1967 The Glass Site. In A Pilot Study of Wichita Indian Archeology and Ethnohistory, edited by Robert E. Bell, Edward B. Jelks, and W. W. Newcomb, pp. 24-44. Final Report for National Science Foundation Grant GS-964.

1969 Archeological Excavations in the Fish Creek Reservoir. Contributions in Anthropology No. 4. Department of Anthropology, Southern Methodist University, Dallas.

Lorrain, Dessamae, and Norma Hoffrichter

1968 The Lower Rockwall Site, Rockwall County, Texas. Archaeological Salvage Project, Southern Methodist University, Dallas.

Lynott, Mark J.

1975 Archaeological Excavations at Lake Lavon, 1974. Contributions in Anthropology No. 16. Department of Anthropology, Southern Methodist University, Dallas.

1977 A Regional Model for Archaeological Research in North Central Texas. Ph.D. dissertation, Department of Anthropology, Southern Methodist University, Dallas.

1979 Survey and Testing in the Elm Creek Watershed, Upper Colorado River Drainage, Texas (Floodwater Retarding Structures 110). Research Report 106. Archeological Research Program, Southern Methodist University, Dallas.

1981 A Model of Prehistoric Adaptation in Northern Texas. Plains Anthropologist 26(92):97-110.

Mack, Steven R.

1994 Archaeological Investigations at the Van York Site (41BD8): A Late Archaic Lithic Scatter in the Western Rolling Plains of Texas. Master's thesis, Department of Anthropology, University of Tulsa.

Mahoney, Richard B., Steve A. Tomka, Raymond P. Mauldin, Harry J. Shafer, Lee C. Nordt, Russell D. Greaves, and Rebecca R. Galdeano

2003 Data Recovery Excavations at 41MM340: A Late Archaic Site along Little River in 
Milam County, Texas. Archaeological Survey Report No. 340. Center for Archaeological Research, The University of Texas at San Antonio. Archeological Studies Program Report No. 54. Environmental Affairs Division, Texas Department of Transportation, Austin.

Mallouf, Robert J.

1981 A Case Study of Plow Damage to Chert Artifacts: The Brookeen Creek Cache, Hill County, Texas. Report No. 33. Office of the State Archeologist, Texas Historical Commission, Austin.

1989 A Clovis Quarry Workshop in the Callahan Divide: The Yellow Hawk Site. Plains Anthropologist 34(124):81-103.

Martin, Ernest R.

1994 The Dillard Site, a Late Prehistoric Village on the Red River in Cooke County, Texas. Bulletin of the Texas Archeological Society 62:105-200.

Mauldin, Raymond P., and David L. Nickels

2003 Burned Rock Middens in Texas. In Archaeological Testing to Determine the $\mathrm{Na}$ tional Register Eligibility Status of 18 Prehistoric Sites on Camp Bowie, Brown County, Texas, by Raymond P. Mauldin, David L. Nickels, and Cory J. Broehm, pp. 217-231. Archaeological Survey Report No. 334. Center for Archaeological Research, The University of Texas at San Antonio.

Mauldin, Raymond P., David L. Nickels, and Cory J. Broehm

2003 Archaeological Testing to Determine the National Register Eligibility Status of 18 Prehistoric Sites on Camp Bowie, Brown County, Texas, Vol 1. Archaeological Survey Report No. 334. Center for Archaeological Research, The University of Texas at San Antonio.

McGowen, J. H., D. E. Owen, M. K. Pieper, and C. A. Shelby

1967 Geologic Atlas of Texas, Sherman Sheet. Bureau of Economic Geology, The University of Texas at Austin.

McGowen, J. H., C. V. Proctor, W. T. Haenggi, D. F. Reaser, and V. E. Barnes

1972 Geologic Atlas of Texas, Dallas Sheet. Bureau of Economic Geology, The University of Texas at Austin.
McKinney, Wilson W.

1981 Early Holocene Adaptations in Central and Southwestern Texas: The Problem of the Paleoindian-Archaic Transition. Bulletin of the Texas Archeology Society 52:91120.

Mehalchick, Gemma, Karl Kleinbach, Douglas K. Boyd, And Karl W. Kibler

2000 Geoarcheological Investigations and $\mathrm{Na}$ tional Register Testing of 52 Prehistoric Archeological Sites on Fort Hood, Texas: The 1997 Season. Research Report No. 39. Archeological Resource Management Series, United States Army Fort Hood.

Mehalchick, Gemma, Karl Kleinbach, Douglas K. Boyd, Steve A. Tomka, and Karl W. Kibler

1999 National Register Testing of 19 Prehistoric Archeological Sites at Fort Hood, Texas: The 1995 Season. Research Report No. 37. Archeological Resource Management Series, United States Army Fort Hood.

Meltzer, David J.

1986 The Clovis Paleoindian Occupation of Texas: Results of the Texas Fluted Point Survey. Bulletin of the Texas Archeological Society 57:27-68.

1991 Altithermal Archaeology and Paleoecology at Mustang Springs, on the Southern High Plains of Texas. American Antiquity 56(2)236-267.

Meltzer, David J., and Michael R. Bever

1995 Paleoindians of Texas: An Update on the Texas Clovis Fluted Point Survey. Bulletin of the Texas Archeological Society $66: 47-81$.

Morgan, Larry W.

1975 An Empirical Analysis of a pre-Neo-American Site in Dallas County, Texas. Master's thesis, Department of Sociology and Anthropology, University of Texas at Arlington.

Morris, Virginia, and Bill Morris

1970 Excavation of Bison Remains in Northwest Dallas County. The Record 27(1):2-5.

Newcomb, W. W., Jr.

1961 The Indians of Texas: From Prehistoric to Modern Times. University of Texas Press, Austin.

1993 Historic Indians of Central Texas. Bulle- 
tin of the Texas Archeological Society 64:163.

Newcomb, W. W., Jr., and T. N. Campbell

1982 Southern Plains Ethnohistory:A Reexamination of the Escanjaques, Ahijados, and Cuitoas. In Pathways to Plains Prehistory: Anthropological Perspectives of Plains $\mathrm{Na}$ tives and Their Pasts, edited by Don G. Wyckoff and Jack L. Hoffman, pp. 29-43. Oklahoma Anthropological Society Memoir 3 and The Cross Timbers Heritage Association Contributions 1. Duncan, Oklahoma.

Nordt, Lee C., Thomas W. Boutton, Charles T. Hallmark, and Michael R. Waters

1994 Late Quaternary Vegetation and Climate Changes in Central Texas Based on the Isotopic Composition of Organic Carbon. Quaternary Research 41: 109-120.

Peter, Duane E., and Daniel E. McGregor (editors) 1988 Late Holocene Prehistory of the Mountain Creek Drainage. Joe Pool Lake Archaeological Project, Vol. I. Archaeology Research Program, Southern Methodist University, Dallas.

Preston, Nolan E.

1969 The McCann Site. Bulletin of the Texas Archeological Society 40:167-192.

Prewitt, Elton R.

1974 Archeological Investigations at the LoeveFox Site, Williamson County, Texas. Research Report 49. Texas Archeological Survey, The University of Texas at Austin.

1981 Cultural Chronology in Central Texas. Bulletin of the Texas Archeological Society 52:65-89.

1982 Archeological Investigations at the LoeveFox Site, Williamson County, Texas. Reprints in Archeology No. 1. Prewitt and Associates, Inc., Austin.

1985 From Circleville to Toyah: Comments on Central Texas Chronology. Bulletin of the Texas Archeological Society 54:201-238.

1995 Distributions of Typed Projectile Points in Texas. Bulletin of the Texas Archeological Society 66:83-173.

Prikryl, Daniel J.

1990 Lower Elm Fork Prehistory:A Redefinition of Cultural Concepts and Chronologies along the Trinity River, North-Central Texas. Report No. 37. Office of the State Archeologist, Texas Historical Commission, Austin.

1993 Regional Preservation Plan for Archeological Resources, Prairie-Savanna Archeological Region: Introduction. In Archeology in the Eastern Planning Region, Texas: A Planning Document, edited by Nancy Adele Kenmotsu and Timothy K. Perttula, pp. 191-204. Cultural Resource Management Report 3. Department of Antiquities Protection, Texas Historical Commission, Austin.

Prikryl, Daniel J., and Bonnie C. Yates

1987 Test Excavations at 41CO141, Ray Roberts Reservoir, Cooke County, Texas. Contributions in Archaeology No. 4. Institute of Applied Sciences, North Texas State University, Denton.

Proctor, C. V., Jr., T. E. Brown, J. H. McGowen, and N. B. Waechter

1981 Geologic Atlas of Texas, Austin Sheet. Bureau of Economic Geology, The University of Texas at Austin.

Proctor, C. V., Jr., J. H. McGowen, and W. T. Haenggi 1970 Geologic Atlas of Texas, Waco Sheet. Bureau of Economic Geology, The University of Texas at Austin.

Ray, Cyrus N.

1929 A Differentiation of the Prehistoric Cultures of the Abilene Region. Bulletin of the Texas Archeological and Paleontological Society 1:7-22.

1930 Report on Some Research in the Abilene Section. Bulletin of the Texas Archeological and Paleontological Society 2:45-58.

1934 Flint Cultures of Ancient Man in Texas. Bulletin of the Texas Archeological and Paleontological Society 5:14-24.

1936 Some Unusual Cremated Burials Found near Colorado, Texas. Bulletin of the Texas Archeological and Paleontological Society 8:9-16.

1938 The Clear Fork Culture Complex. Bulletin of the Texas Archeological and Paleontological Society 10:193-207. 
1940 The Deeply Buried Gibson Site. Bulletin of the Texas Archeological and Paleontological Society 12:223-237.

1945 Stream Bank Silts of the Abilene Region. Bulletin of the Texas Archeological and Paleontological Society 16:117-147.

Ray, Cyrus N., and Kirk Bryan

1938 Folsomoid Point Found in Alluvium Beside Mammoth's Bones. Science 88(2281):257258.

Ray, Cyrus N., and E. B. Sayles

1941 An Agreement on Abilene Region Terminology. Bulletin of the Texas Archeological and Paleontological Society 13:175-176.

Redder, Albert J.

1985 Horn Shelter Number 2: The South End, A Preliminary Report. Central Texas Archeologist 10:37-65.

Ricklis, Robert A., and Michael B. Collins

1994 Archaic and Late Prehistoric Human Ecology in the Middle Onion Creek Valley, Hays County, Texas. Studies in Archeology 19. Texas Archeological Research Laboratory, The University of Texas at Austin.

Ross, Richard E.

1966 The Upper Rockwall and Glen Hill Sites, Forney Reservoir, Texas. Papers of the Texas Archeological Salvage Project No. 9. The University of Texas at Austin.

Saunders, Joe W., C. S. Mueller-Wille, and David L. Carlson (editors)

1992 An Archeological Survey of the Proposed South Bend Reservoir Area: Young, Stephens, and Throckmorton Counties, Texas. Archeological Surveys No. 6. Archeological Research Laboratory, Texas A\&M University, College Station.

Sayles, E. B.

1935 An Archeological Survey of Texas. Medallion Papers No. 17. Gila Pueblo, Globe, Arizona.

Scott, Ann M., Karl W. Kibler, and Marie E. Blake 2002 National Register Testing of Nine Archeological Sites at Waco Lake, McLennan County, Texas. Reports of Investigations No. 132. Prewitt and Associates, Inc., Austin.
Sellards, E. H.

1952 Early Man in America: A Study in Prehistory. University of Texas Press, Austin.

Shafer, Harry J.

1963 Test Excavations at the Youngsport Site: A Stratified Terrace Site in Bell County, Texas. Bulletin of the Texas Archeological Society 34:57-81.

1971 Investigations into South Plains Prehistory, West Central Texas. Papers of the Texas Archeological Salvage Project No. 20. The University of Texas at Austin.

Skinner, S. Alan

1971 Prehistoric Settlement of the De Cordova Bend Reservoir, Central Texas. Bulletin of the Texas Archeological Society 42:149269.

Skinner, S. Alan, M. B. Cliff, L. Baird, A. B. Amerson Jr., J. Bennett, A. R. Faust, J. Kaskey, K. Ludden, M. D. Northern, A. Pitchford, J. Raley, D. G. Shaddox, and D. Shanabrook

1982 The Archaeology and History of Lake Ray Roberts, Vol. 1: Cultural Resources Survey. Cultural Resources Report 82-6. Environmental Consultants, Inc., Dallas.

Sollberger, J. B., and Thomas R. Hester

1972 The Stonehacker Site: A Review of Pre-Archaic Manifestations in Texas. Plains Anthropologist 17(58, part 1):326-344.

Sorrow, William M.

1966 The Pecan Springs Site, Bardwell Reservoir, Texas. Papers of the Texas Archeological Salvage Project No. 10. The University of Texas at Austin.

1969 Archeological Investigations at the John Ischy Site: A Burned Rock Midden in Williamson County, Texas. Papers of the Texas Archeological Salvage Project No. 18. The University of Texas at Austin.

Sorrow, William, Harry J. Shafer, and Richard Ross 1967 Excavations at Stillhouse Hollow Reservoir. Papers of the Texas Archeological Salvage Project No. 11. The University of Texas at Austin.

Spearing, Darwin

1991 Roadside Geology of Texas. Mountain Press Publishing Company, Missoula, Montana. 
Staley, David P., and John A. Evaskovich 1993 A Cultural Resource Survey for Cap Rock Electric Cooperative Proposed Transmission Lines, Borden, Howard, Martin, and Midland Counties, Texas. Project 695. Mariah and Associates, Inc., Albuquerque.

Stephenson, Robert L.

1949 Archaeological Survey of Lavon and Garza-Little Elm Reservoirs: A Preliminary Report. Bulletin of the Texas Archeological and Paleontological Society 20:2162.

1950 Archeological Survey of Garza-Little Elm Reservoir, Denton County, Texas. River Basin Surveys, Austin Office, Smithsonian Institution, Washington. D.C.

1952 The Hogge Bridge Site and the Wylie Focus. American Antiquity 17(4):299-312.

1970 Archeological Investigations in the Whitney Reservoir Area, Central Texas. Bulletin of the Texas Archeological Society 41:37-277.

Story, Dee Ann

1985a Adaptive Strategies of Archaic Cultures of the West Gulf Coastal Plain. In Prehistoric Food Production in North America, edited by R. I. Ford, pp. 19-56. Anthropological Papers 75. Museum of Anthropology, University of Michigan, Ann Arbor.

1985b The Walton Site: An Historic Burial in McLennan County, Texas. Central Texas Archeologist 10:66-96.

1990 Cultural History of the Native Americans. In The Archeology and Bioarcheology of the Gulf Coastal Plain, by Dee Ann Story, Janice A. Guy, Barbara A. Burnett, Martha Doty Freeman, Jerome C. Rose, D. Gentry Steele, Ben W. Olive, and Karl J. Reinhard, pp. 163-366. Research Series No. 38. Arkansas Archeological Survey, Fayetteville.

Story, Dee Ann, and Harry J. Shafer

19651964 Excavations at Waco Reservoir, McLennan County, Texas: The Baylor and Britton Sites. Miscellaneous Papers No. 6. Texas Archeological Salvage Project, The University of Texas at Austin.

Suhm, Dee Ann

1957 Excavations at the Smith Rockshelter, Travis County, Texas. Texas Journal of Science 9(1):26-58.
1960 A Review of Central Texas Archeology. Bulletin of the Texas Archeological Society 29:63-107.

Suhm, Dee Ann, Alex D. Krieger, and Edward B. Jelks 1954 An Introductory Handbook of Texas Archeology. Bulletin of the Texas Archeological Society 25.

Takac, Paul R.

1991 Underwater Excavations at Spring Lake: A Paleoindian Site in Hays County, Texas. Current Research in the Pleistocene 8:4648.

Thurmond J. Peter, Martha Doty Freeman, and Susan L. Andrews

1981 A Preliminary Assessment of the Cultural Resources in the Brazos Natural Salt Pollution Control Project, Kent, King, and Stonewall Counties, Texas. Reports of Investigations No. 18. Prewitt and Associates, Inc., Austin.

Toomey, Rickard S., III, Michael D. Blum, and Salvatore Valastro Jr.

1993 Late Quaternary Climates and Environments of the Edwards Plateau, Texas. Global and Planetary Change 7:299-320.

Treece, Abby C., Christopher Lintz, W. Nicholas Trierweiler, J. Michael Quigg, and Kevin A. Miller

1993a Cultural Resource Investigations in the $O$. H. Ivie Reservoir, Concho, Coleman, and Runnels Counties, Texas, Volume III: Data Recovery Results from Non-Ceramic Sites. Technical Report No. 346-III. Mariah Associates, Inc., Austin.

1993b Cultural Resource Investigations in the $O$. H. Ivie Reservoir, Concho, Coleman, and Runnels Counties, Texas, Volume IV: Data Recovery Results from Ceramic Sites. Technical Report No. 346-IV. Mariah Associates, Inc., Austin.

Tunnell, Curtis

1960 Appraisal of the Archeological Resources of Champion Creek Reservoir, Mitchell County, Texas. Report Submitted to the National Park Service by the Texas Archeological Salvage Project, The University of Texas at Austin.

1975 Fluted Projectile Points as Revealed by Lithic Specimens from the AdairSteadman Sites in Northwest Texas. Spe- 
cial Report 18. Office of the State Archeologist, Texas Historical Commission, Austin.

1978 The Gibson Lithic Cache from West Texas. Report No. 30. Office of the State Archeologist, Texas Historical Commission, Austin.

Turner, Ellen Sue, and Thomas R. Hester

1999 A Field Guide to Stone Artifacts of Texas Indians. 3rd ed. Gulf Publishing, Lanham.

Wade, Mariah F.

1999 Unfolding Native American History: The Entrada of Fr. Manuel de la Cruz and the Bosque-Larios Expedition. Bulletin of the Texas Archeological Society 70:29-48.

Wallace, Ernest, and E. Adamson Hoebel 1986 The Comanches: Lords of the Southern Plains. University of Oklahoma Press, Norman.

Wandsnider, L.

1997 The Roasted and the Boiled: Food Composition and Heat Treatment with Special Emphasis on Pit-Hearth Cooking. Journal of Anthropological Archaeology 16:1-48.

Watt, Frank H.

1953 Pottery Diffusions of the Central Brazos Valley. Central Texas Archeologist 6:57-85.

1978 Radiocarbon Chronology of Sites in the Central Brazos Valley. Bulletin of the Texas Archeological Society 49:111-138.

Weir, Frank A.

1976 The Central Texas Archaic. Ph.D. dissertation, Department of Anthropology, Washington State University, Pullman.

Wendorf, Fred, and James J. Hester

1975 Late Pleistocene Environments of the Southern High Plains. Publication No. 9. Fort Burgwin Research Center, Taos, New Mexico.

Wesolowsky, Al B., Thomas R. Hester, and Douglas R. Brown

1976 Archeological Investigations at the Jetta Court Site (41TV151) Travis County, Texas. Bulletin of the Texas Archeological Society 47:25-87.

Willey, Gordon R., and Philip Phillips 1958 Method and Theory in American Archae- ology. University of Chicago Press, Chicago.

Wilson, E. W.

1930 Burnt Rock Mounds of Southwest Texas. Bulletin of the Texas Archaeological and Paleontological Society 2:59-63.

Wilson, Lester

1946 Problematical Pits on East Fork. The Record 5(2):11-12.

Woodall, J. Ned

1967a The Coyote Site. In A Pilot Study of Wichita Indian Archeology and Ethnohistory, edited by Robert E. Bell, Edward B. Jelks, and W. W. Newcomb, pp. 15-23. Final Report for National Science Foundation Grant GS-964.

1967b The Upper Tucker Site. In A Pilot Study of Wichita Indian Archeology and Ethnohistory, edited by Robert E. Bell, Edward B. Jelks, and W. W. Newcomb, pp. 314. Final Report for National Science Foundation Grant GS-964.

Woodhouse, C. A., and J. T. Overpeck

19982000 Years of Drought Variability in the Central United States. Bulletin of the American Meteorological Society 79:26932714.

Wormington, H. M

1957 Ancient Man in North America. Denver Museum of Natural History, Denver, Colorado.

Wulfkuhle, Virginia A.

1986 Investigations into the Prehistory of the Upper Clear Fork of the Brazos River: Fisher and Jones Counties, Texas. Master's thesis, Department of Anthropology, The University of Texas at Austin.

Yedlowski, Joseph L., Kevin J. Shaunessy, David H. Jurney, and J. M. Adovasio

1998 Archaeological Investigations in Support of the Superconducting Super Collider, Ellis County, Texas. Archaeology Research Program, Mercyhurst College, Erie.

Young, Bill, and Michael B. Collins

1989 A Cache of Blades with Clovis Affinities from Northeastern Texas. Current Research in the Pleistocene 6:26-28. 

APPENDIX A: Glossary of Technical Terms 

Arrow point: Point used to tip an arrow, which is propelled by a bow.

Biface: Piece of conchoidally fracturing stone that has had flakes removed from both faces to create a tool.

Core: Piece of lithic material from which one or more flakes have been removed.

Dart point: Point used to tip a throwing spear or dart, which is propelled by an atlatl.

Debitage: Debris generated by the removal through percussion or pressure of flakes, chips, and chunks to make stone tools.

Fill section: Introduced fill used to elevate the approaches to a bridge above the surrounding terrain.

Flake: Generally thin piece of conchoidally fracturing stone with a positive bulb of percussion showing that it was removed from the parent piece by percussion or pressure.

Hammerstone: Rock used as a hammer, e.g., in making stone tools, crushing nuts, etc.

Impact Evaluation: Onsite inspection documenting existing damage or other conditions that may preclude the presence of intact archeological deposits within the project area for a proposed Transportation Activity.

Megafauna: Very large animal.

Midden: Accumulation of occupational debris, particularly organic remains, burned rocks, or shells.

Projectile point: Inclusive term for arrow and dart points.

Sherd: A piece of broken pottery.

Survey: Fieldwork to locate archeological remains within the project area for a proposed Transportation Activity, including on-foot examination of the surface, shovel testing, and trenching by mechanical means where appropriate.

Transportation Activity: any proposed project involving the development, design, construction, or maintenance of the state's intermodal transportation system. 

APPENDIX B: Letters and Letter Reports for Impact Evaluations and Surveys 

The interim reports for the Impact Evaluations and Surveys are on the included CD-ROM. Authors of the reports were Cory J. Broehm, Ross C. Fields, Tim Gibbs, Timothy B. Griffith, Karl W. Kibler, and Jennifer K. McWilliams. 
